\title{
Ocena struktury oraz właściwości złączy spawanych hybrydowo (laser + MAG) paneli ścian szczelnych ze stali austenitycznej typu 304
}

\author{
Evaluation of structure and properties \\ of hybrid (laser + MAG) welded joints of membrane wall panels \\ made from austenitic steel type 304
}

\section{Streszczenie}

W artykule przedstawiono wyniki oceny jakości złączy spawanych hybrydowo (laser + MAG) paneli ścian szczelnych ze stali austenitycznej typu 304. Ocenie poddano makroi mikrostrukturę złączy przy zastosowaniu mikroskopii świetlnej oraz elektronowej mikroskopii skaningowej. Przeprowadzono również technologiczną próbę rozciągania, aby określić właściwości wytrzymałościowe złączy. Na podstawie analizy wyników przeprowadzonych badań stwierdzono, że zastosowanie spawania hybrydowego (laser + MAG) dla paneli ścian szczelnych ze stali austenitycznych, przy odpowiednich parametrach procesu spawania, spełnia wymagania poziomu jakości B wg PN-EN ISO 13919.

Słowa kluczowe: spawanie hybrydowe; ściany szczelne; stal austenityczna

\begin{abstract}
The paper presents the results of quality evaluation of hybrid welded (laser + MAG) joints of membrane wall panels made from austenitic steel type 304 . The macro- and microstructure have been assessed by use of light microscopy and scanning electron microscopy. There has been also conducted technological tensile test to estimate the strength properties of joints. Based on the results, it has been found that application of hybrid (laser + MAG) welding process to produce membrane wall panels made of austenitic steels, using the suitable welding process parameters, meets the requirements of the quality level $\mathrm{B}$ specified in PN-EN ISO 13919.
\end{abstract}

Keywords: hybrid welding; membrane walls; austenitic steel

\section{Wstęp}

Priorytety polityczne Unii Europejskiej w zakresie energetyki, tzw. 3×20\%, dotyczą zwiększenia sprawności cieplnej kotłów oraz redukcji emisji szkodliwych substancji do atmosfery. Chcąc wdrożyć unijne dyrektywy, należy podjąć działania mające na celu modernizację starych oraz budowę nowych bloków energetycznych o parametrach ultranadkrytycznych, zapewniających sprawność netto na poziomie $50 \%$ [1]. Na trwałość oraz dyspozycyjność kotła w głównej mierze wpływa stan elementów należących do jego części krytycznej. Szczególne znaczenie ma komora paleniskowa, w której zasadniczą funkcję pełnią panele ścian szczelnych [2]. W instalacjach o parametrach nadkrytycznych ściany membranowe mogą pracować przy ciśnieniu do ok. $30 \mathrm{MPa}$ i temperaturze do $550^{\circ} \mathrm{C}[2,3]$. Im wyższe parametry pary, tym większe pojawiają się problemy materiałowe i technologiczne. Istotnym czynnikiem mającym wpływ na wzrost sprawności cieplnej jest technologia wytwarzania paneli ścian szczelnych. Do powszechnie stosowanych technologii zalicza się spawanie łukiem krytym. Jest to stabilny proces, gdzie podczas wykonywania długich spoin można osiągnąć dużą wydajność [4]. Jednak ciągły rozwój technologii łączenia elementów skutkuje zastosowaniem nowoczesnych rozwiązań technologicznych, do których należy spawanie laserowe lub hybrydowe. Połączenie metod spawania łukowego $z$ laserem $w$ jeden proces daje szereg korzyści w porównaniu do metody spawania łukiem krytym. Spawanie hybrydowe gwarantuje uzyskanie kilkukrotnie mniejszej spoiny z mniejszą SWC oraz z pełnym przetopieniem, nawet przy różnych grubościach ścianki rury i płaskownika. Uzyskanie pełnego przetopu złącza, możliwe tylko przy zastosowaniu technik laserowych, zapewnia prawidłowy przepływ ciepła oraz zwiększenie sprawności kotła [5].

Mgr inż. Anna Kamela - Politechnika Śląska.

Autor korespondencyjny/Corresponding author: anna.kamela@polsı.pl 
Do materiałów obecnie stosowanych na ściany szczelne kotłów należą stale niestopowe o strukturze ferrytycznej takie jak P235, P265, P355 oraz stale niskostopowe typu C-Mo, C-CrMo np. 16Mo3, 13CrMo4-5 [5]. Jednak podnoszenie parametrów pary do poziomu pozwalającego uzyskać sprawność netto na poziomie 50\% wymaga zastąpienia materiałów konwencjonalnych nowymi [1]. Alternatywę stanowią stale austenityczne, które ze względu na obecne warunki pracy kotłów nie znajdują zastosowania do budowy ekranów ścian szczelnych. Wciąż rosnące wymagania UE przyczyniają się do prowadzenia badań nad zmianą osnowy ferrytycznej na austenityczną, co pozwala uzyskać znaczny wzrost żaroodporności i żarowytrzymałości [3].

Wpływ spawania hybrydowego laser + MAG na strukturę i właściwości złączy spawanych ścian membranowych wykonanych ze stali austenitycznych nie jest opisany w literaturze. Stąd konieczność oceny struktury oraz właściwości paneli ścian szczelnych wytwarzanych tą technologią. Dane te są niezbędnym elementem procesu projektowania ścian szczelnych w nowoczesnych blokach energetycznych, pozwalającym na ich efektywną eksploatację.

\section{Materiał do badań}

Do badań wykorzystano element paneli ścian szczelnych wykonany ze stali austenitycznej w gatunku 304 (X5CrNi18-10; 1.4301 wg EN 10088-1) o składzie chemicznym podanym $w$ tablicy I. Element składał się z rury $\emptyset 38 \mathrm{~mm}$ x 3,6 mm połączonej z płaskownikiem o wymiarach $15 \mathrm{~mm} \times 3 \mathrm{~mm}$ (rys. 1). Długość złącza spawanego wyniosła $1 \mathrm{~m}$. Próbkę wykonano w Energoinstal SA stosując technologię spawania hybrydowego laser + MAG, z prędkością spawania $1 \mathrm{~m} / \mathrm{min}$, wiązką laserową o mocy $2,25 \mathrm{~kW}$. Proces spawania MAG prowadzono przy natężeniu prądu spawania $120 \mathrm{~A}$ i napięciu $23,5 \mathrm{~V}$.

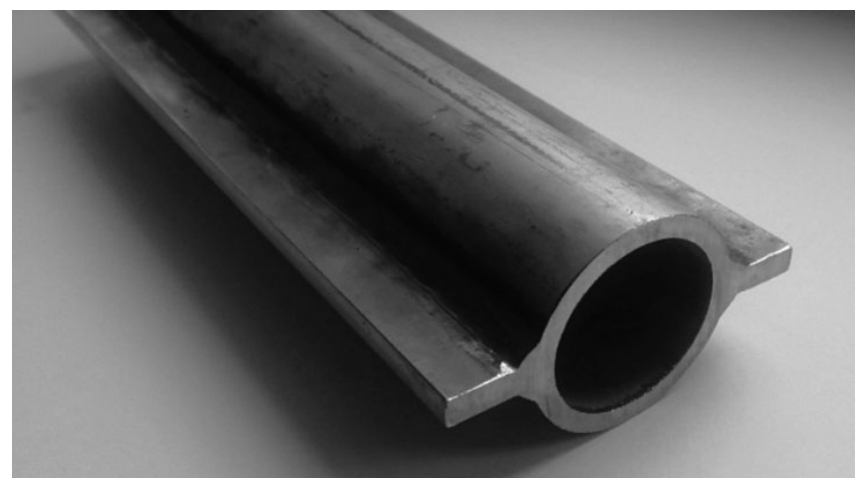

Rys. 1. Element paneli ścian szczelnych wykonany w Energoinstal SA Fig. 1. The element of membrane wall panels produced by Energoinstal SA

\section{Metodyka i wyniki badań}

\section{Badania wizualne}

W celu oceny jakości złącza spawanego hybrydowo przeprowadzono badanie wizualne zgodnie z PN-EN ISO 17637 na całej długości spoiny. Na podstawie przyjętego poziomu jakości B wg PN-EN ISO 13919-1 nie stwierdzono występowania niezgodności spawalniczych. Przykładowe lico spoiny pokazano na rysunku 2.

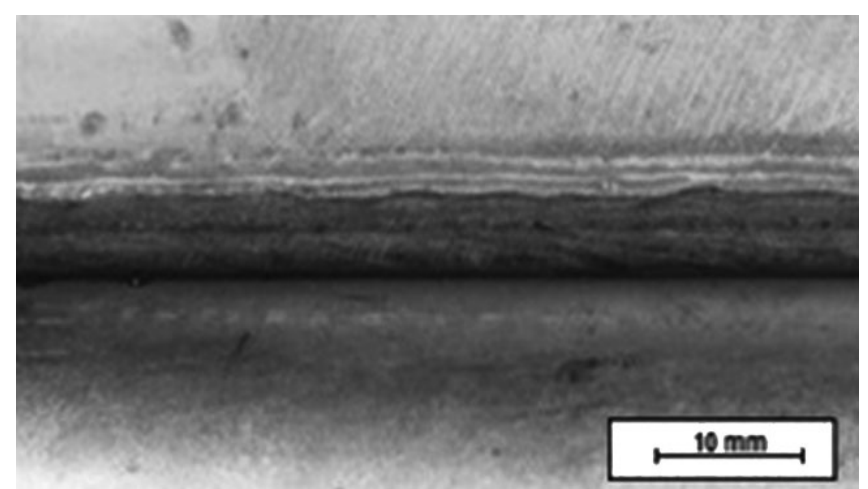

Rys. 2. Lico spoiny

Fig. 2. Face of the weld

\section{Badania metalograficzne}

Kolejnym etapem badań była ocena metalograficzna struktury. Próbka do badań została wycięta prostopadle do kierunku spawania. Następnie próbkę szlifowano, polerowano oraz trawiono elektrochemicznie przy $6 \mathrm{~V}$ w $10 \%$ roztworze kwasu szczawiowego przez $60 \mathrm{~s}$. Badania metalograficzne prowadzono na mikroskopie świetlnym Olympus GX71 w technice pola jasnego. Obserwacje struktury wykonano przy powiększeniu 500x (rys. 3). Analizę struktury przy większych powiększeniach (do 10000x) wykonano stosując elektronowy mikroskop skaningowy (SEM). Mikroskop wyposażony jest w spektrometr EDS, który wykorzystano do mikroanalizy składu chemicznego (rys. 4). Następnie wykonano liniowy rozkład pierwiastków w złączu spawanym (rys. 5).

$\mathrm{Na}$ podstawie obserwacji metalograficznych stwierdzono, że struktura materiału rury i płaskownika zbudowana jest $z$ ziaren austenitu, $z$ widocznymi wydzieleniami ferrytu $\delta$ wewnątrz oraz po granicach ziaren (rys. 3a, 3e). Przy linii wtopienia od strony rury i płaskownika ujawniono strefy nadtopienia granic ziaren (rys. 3b, 3d). Obszar spoiny zbudowany jest z dendrytów narastających w kierunku odprowadzania ciepła podczas procesu spawania (rys. 3c). W spoinie ujawniono występowanie pęcherzy gazowych, o kształcie zbliżonym do kulistego i średnicy nieprzekraczającej $200 \mu \mathrm{m}$. W badanym złączu nie ujawniono innych niezgodności spawalniczych.

Tablica I. Skład chemiczny stali 304 (\% mas.)

Table I. Chemical composition of 304 steel (wt. \%)

\begin{tabular}{|c|c|c|c|c|c|c|c|c|c|}
\hline & $\mathbf{C}$ & Mn & $\mathbf{P}$ & $\mathbf{S}$ & $\mathbf{S i}$ & $\mathbf{C r}$ & $\mathbf{N i}$ & $\mathbf{N}$ & $\mathbf{F e}$ \\
\hline EN 10088-1 & $\max 0,070$ & $\max 2,00$ & $\max 0,040$ & $\max 0,015$ & $\max 1,00$ & $17,50 \div 19,50$ & $8,00 \div 10,50$ & $\max 0,110$ & reszta \\
\hline rura & 0,021 & 1,64 & 0,038 & 0,004 & 0,50 & 18,68 & 9,00 & 0,032 & reszta \\
\hline płaskownik & 0,024 & 1,81 & 0,030 & $<0,001$ & 0,32 & 18,10 & 8,00 & 0,044 & reszta \\
\hline
\end{tabular}




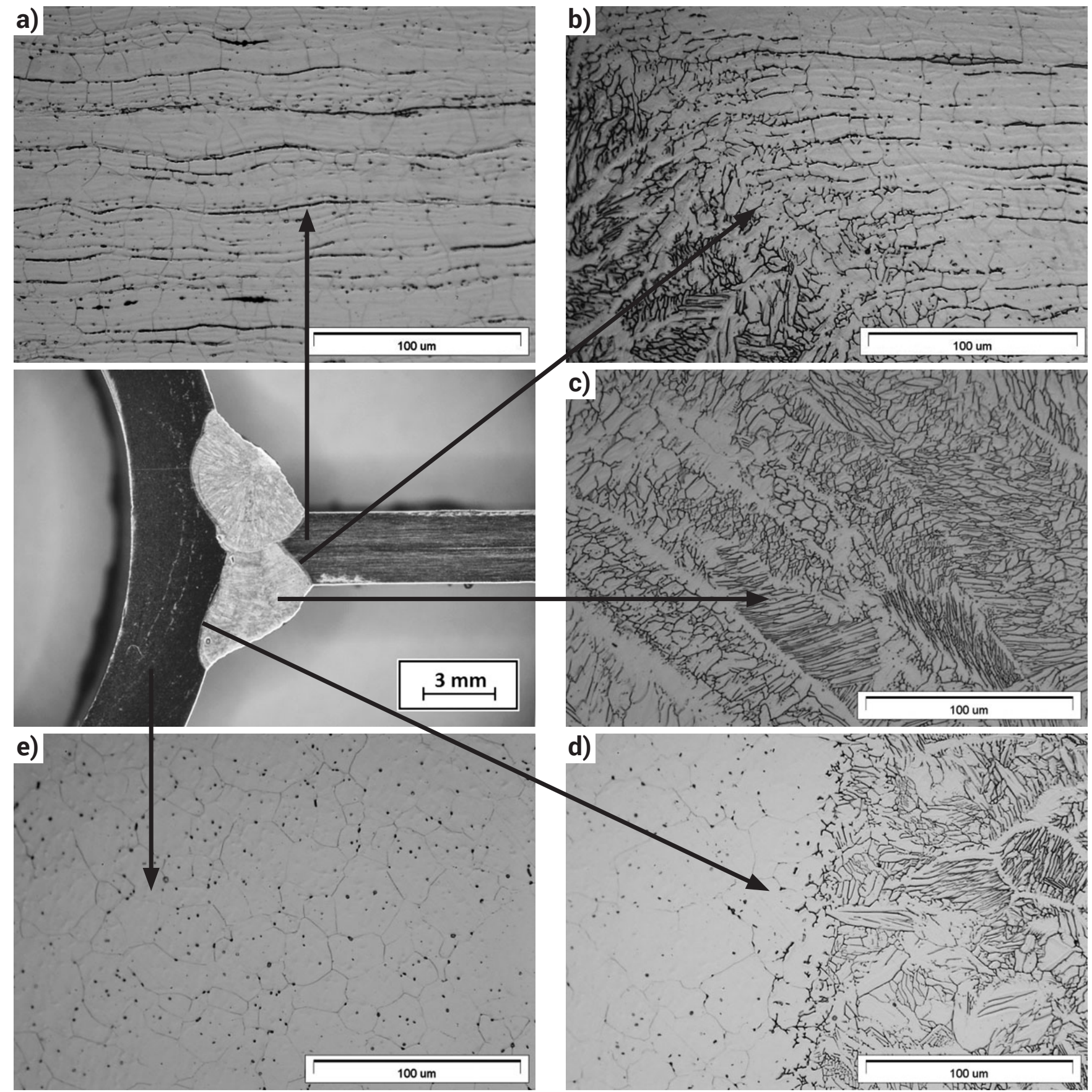

Rys. 3. Struktura złącza rura - płaskownik spawanego hybrydowo: a) materiał płaskownika, b) linia wtopienia od strony płaskownika, c) spoina, d) linia wtopienia od strony rury, e) materiał rury

Fig. 3. Microstructure of plate - tube hybrid welded joint: a) plate material, b) fusion line from the plate side, c) weld, d) fusion line from the tube side, e) tube material

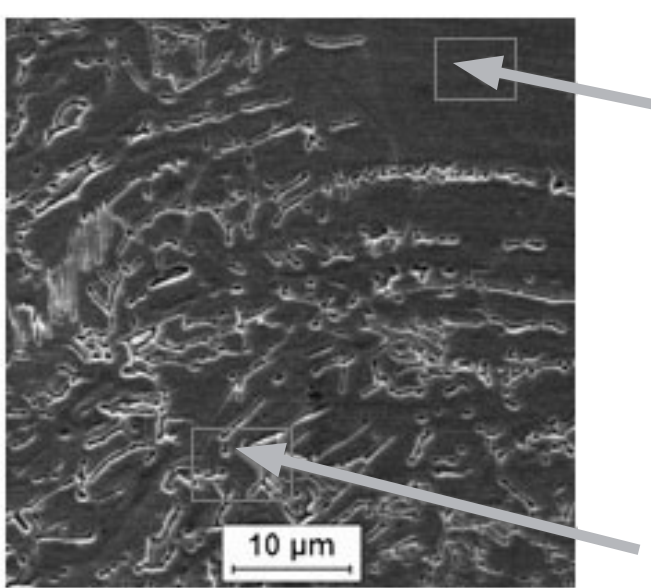

Rys. 4. Wyniki mikroanalizy składu chemicznego EDS złącza

Fig. 4. Results of EDS chemical composition microanalysis of the joint
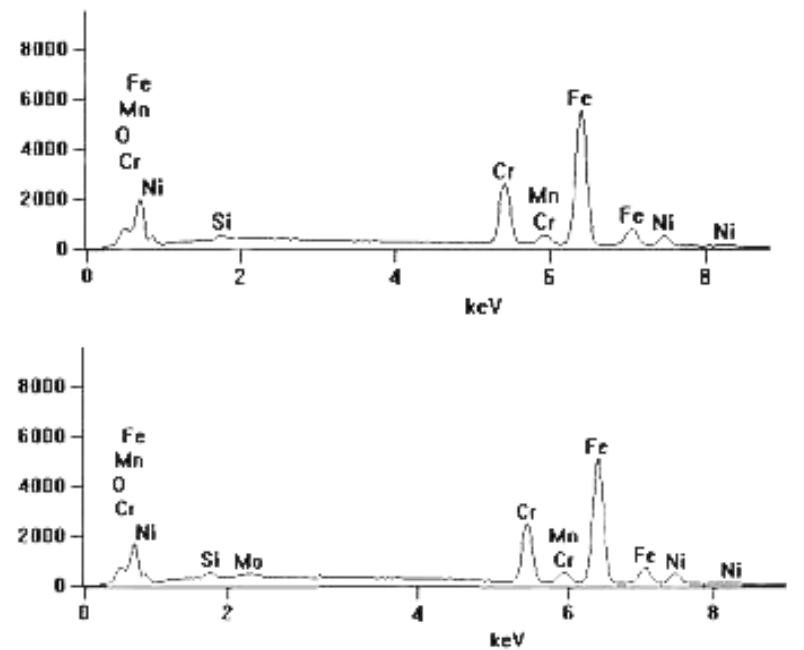


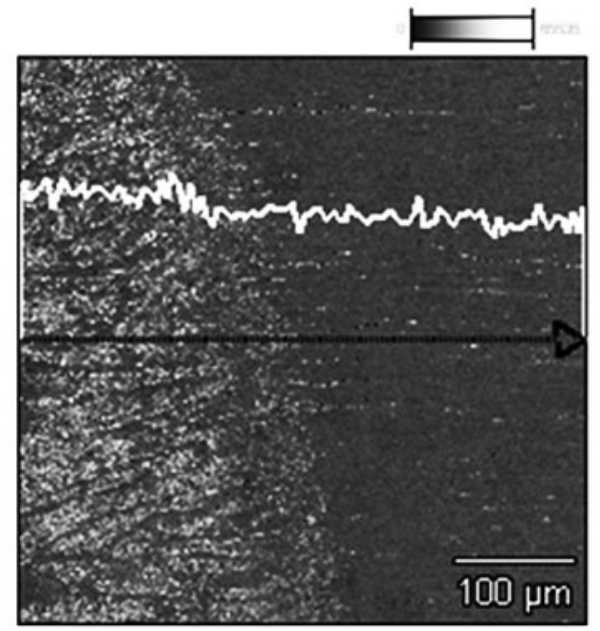

Rys. 5. Liniowy rozkład pierwiastków w złączu Fig. 5. Linear distribution of elements in the joint

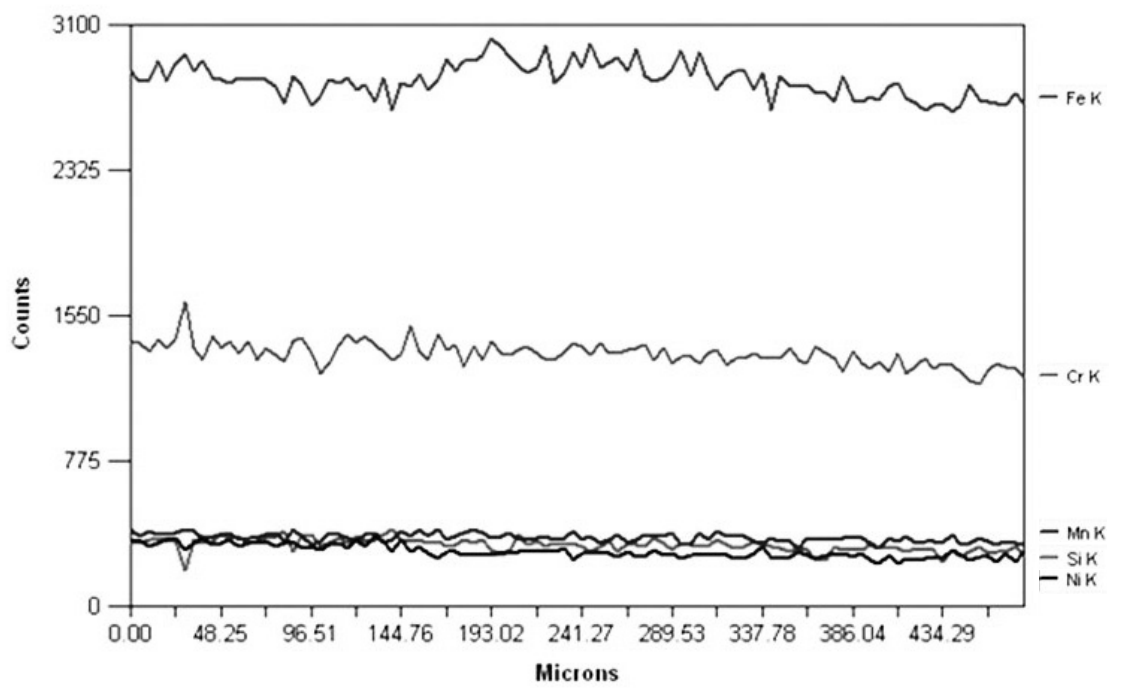

Na podstawie mikroanalizy składu chemicznego (rys. 4) oraz rozkładu liniowego (rys. 5) wynika, że zmiany stężenia pierwiastków w każdej ze stref złącza są nieznaczne, co wskazuje na dużą jednorodność składu chemicznego.

\section{Technologiczna próba rozciągania}

Technologiczną próbę rozciągania wykonano, aby porównać wytrzymałość połączenia spawanego z wytrzymałością materiału rodzimego. Do badania zostały przygotowane fragmenty złącza, które zostały wycięte prostopadle do kierunku spawania (rys. 6a). Próbę odrywania przeprowadzono na maszynie wytrzymałościowej Cometech LCX-300. Wykres z próby rozciągania pokazano na rysunku 7 . W czterech próbkach zerwanie nastąpiło poza spoiną, $w$ materiale płaskownika. W jednej do zerwania doszło w miejscu SWC od strony płaskownika (rys. 6b, próbka nr 4). Mogło być to spowodowane obecnością pęcherzy w spoinie, które osłabiają właściwości wytrzymałościowe złącza. Podczas procesu odkształcania pęcherze oraz braki przetopienia stanowią miejsca zarodkowania i rozprzestrzeniania się pęknięć (rys. 8). Na podstawie przeprowadzonej próby rozciągania stwierdzono, że wytrzymałość połączenia spawanego hybrydowo jest większa od wytrzymałości materiału rodzimego.

\section{a)}

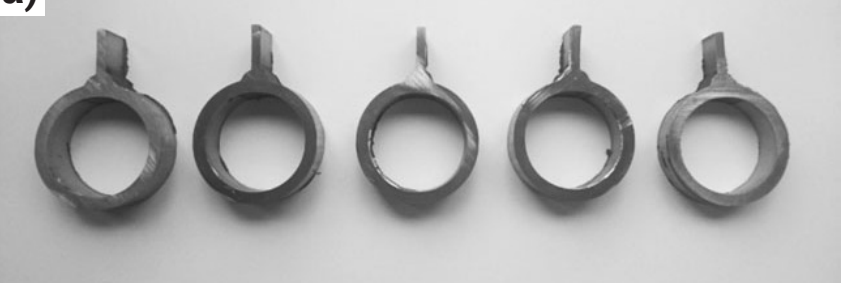

b)

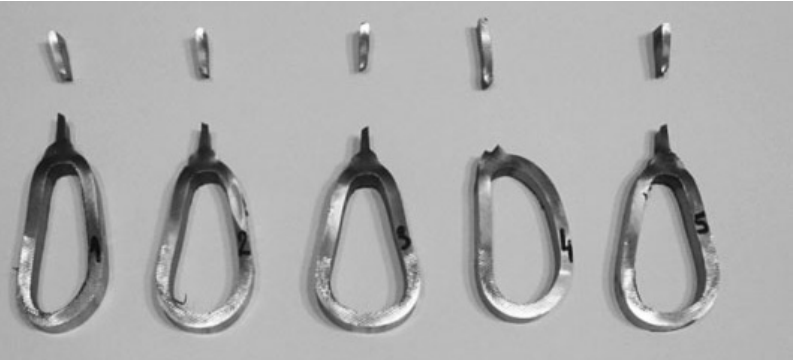

Rys. 6. Wyniki próby rozciągania złącza rura - płaskownik: a) próbki przygotowane do badania, b) próbki po zerwaniu

Fig. 6. Results of tensile strength test for plate - tube welded joint: a) samples prepared for test, b) samples after rupture

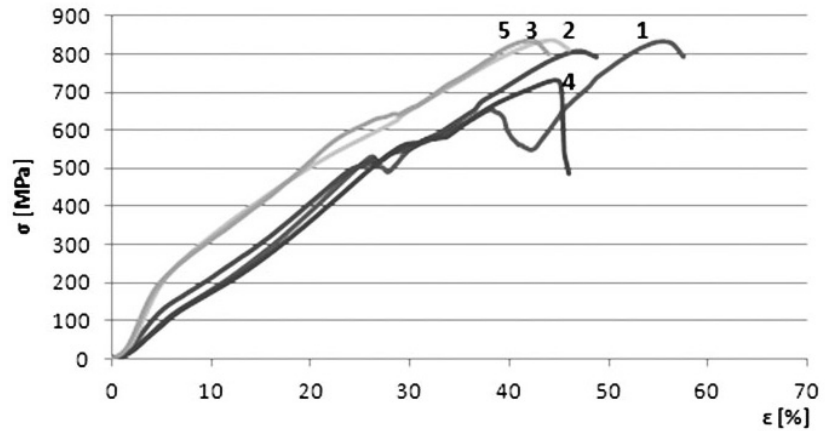

Rys. 7. Krzywe rozciągania dla badanych złączy Fig. 7. Stretching curves for tested joints
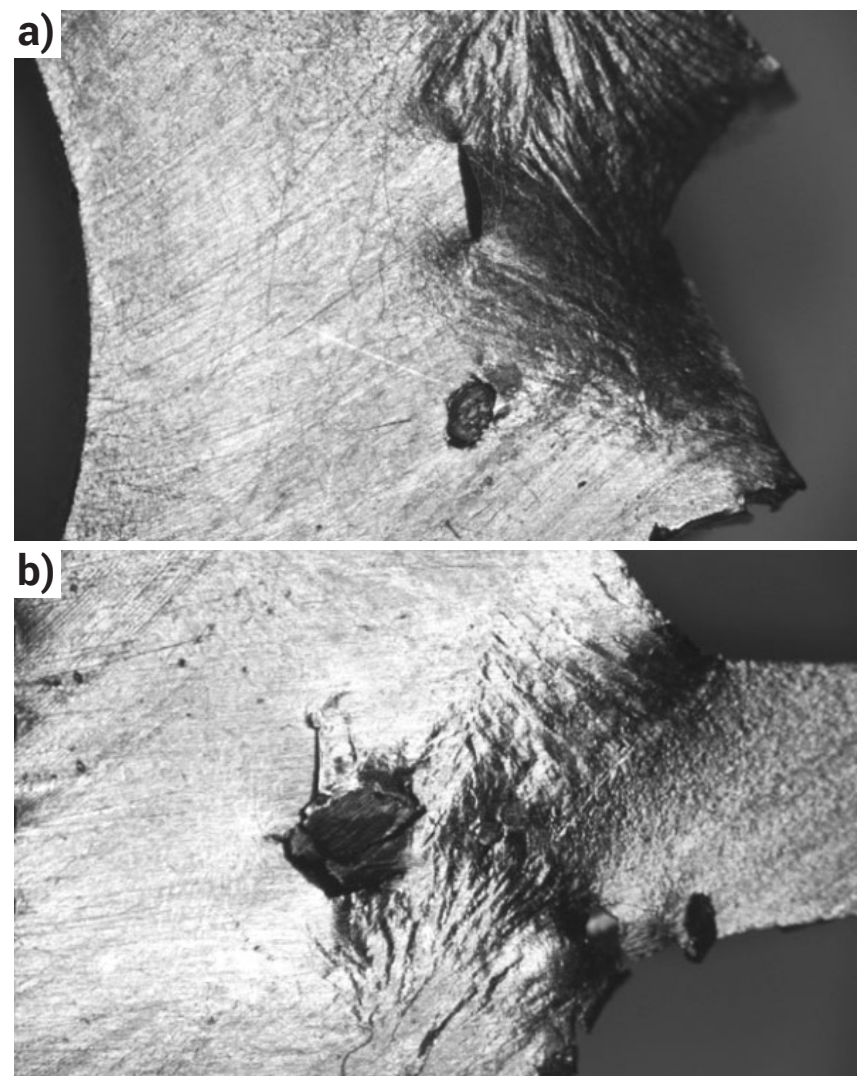

Rys. 8. Przykładowe złącza po rozciąganiu w miejscu niezgodności spawalniczych

Fig. 8. Exemplary joints after stretching in place of welding imperfections 


\section{Podsumowanie}

Stale austenityczne należą do grupy stali dobrze spawalnych, jednak wymagane jest stosowanie odpowiednich procedur spawania, w celu uniknięcia występowania niezgodności spawalniczych. Przeprowadzone badania struktury i właściwości elementu paneli ścian szczelnych spawanego hybrydowo oraz analiza wyników wskazują, że spoina jest ciągła, bez niezgodności spawalniczych, zgodnie z poziomem jakości B wg PN-EN ISO 13919 (rys. 2). Obszar spoiny wykazuje strukturę austenityczną, komórkowo dendrytyczną (rys. 3c). Dużą jednorodność struktury, o składzie chemicznym zbliżonym do materiału podstawowego, potwierdzają wyniki analizy składu chemicznego (rys. 4, rys. 5). Badania metalograficzne wykazały obecność w spoinie pęcherzy gazowych, o kształcie zbliżonym do kulistego i średnicy nieprzekraczającej $200 \mu$ m. Zerwanie próbek poza spoiną w technologicznej próbie rozciągania świadczy o większej wytrzymałości połączenia spawanego od materiału płaskownika (rys. 6b). Zerwanie jednej próbki w miejscu SWC od strony płaskownika może być spowodowane obecnością pęcherzy w spoinie oraz niepełnego przetopienia. Tego rodzaju niezgodności spawalnicze wpływają na osłabienie właściwości wytrzymałościowych złączy oraz stanowią miejsca inicjacji pęknięć podczas procesu odkształcania (rys. 8). Technologia spawania MAG charakteryzuje się skłonnością do występowania pęcherzy w spoinie, dlatego spawając stale austenityczne metodą hybrydową (laser + MAG) należy zapewnić szczególną czystość procesu oraz stabilne warunki spawania.

\section{Literatura}

[1] Hernas A.: Uwarunkowania rozwoju krajowej energetyki, w: Materiały i technologie stosowane w budowie kotłów nadkrytycznych i spalarni odpadów, wyd. SITPH, Katowice, 2009.

[2] Hernas A.: Trwałość i niszczenie elementów kotłów i turbin parowych, wyd. Politechniki Śląskiej, Gliwice, 2003.

[3] Hernas A.: Żarowytrzymałość stali i stopów, wyd. Pol. Śl., Gliwice, 2000.
[4] Słania J., Urbańczyk P.: Zapewnienia jakości produkcji oraz technologia spawania gazoszczelnych ścian rurowych" Dozór Techniczny 3/2011, s. 50-55.

[5] Adamiec J., Gawrysiuk W., Więcek M.: Nowe możliwości spawania hybrydowego laser + mag paneli ścian szczelnych, III Międzynarodowa N-T Konferencja Spawalnicza, Ostaniec, 2013. 


\title{
Ocena wyników badań złączy spawanych techniką phased array wg PN-EN ISO 19285
}

\author{
Evaluation of phased array test results of welded joints \\ according to PN-EN ISO 19285
}

\section{Streszczenie}

W pracy przedstawiono sposób oceny wskazań wykrytych w badaniach złączy spawanych techniką phased array na podstawie PN-EN ISO 19285. Przedstawiono ocenę i klasyfikację wskazań bazującą na długości i wysokości, którą uzupełniono licznymi przykładami. Omówiono również ocenę bazującą na długości i amplitudzie wskazań oraz przedyskutowano zasadność stosowania tego wariantu oceny. Artykuł kierowany jest do personelu badań nieniszczących oraz personelu spawalniczego, zainteresowanego tematyką nowoczesnych technik badań ultradźwiękowych.

Słowa kluczowe: badania nieniszczące; badania ultradźwiękowe spoin; technika phased array

\begin{abstract}
The paper presents a method of evaluating indications detected in the studies of welded joints using the phased array technique based on PN-EN ISO 19285. The evaluation and classification of indications based on their length and height, which was supplemented with numerous examples, was presented. An assessment based on the length and amplitude of the indications was discussed and the validity of the use of this evaluation variant was discussed. The article is addressed to non-destructive testing and welding personnel interested in the subject of advanced ultrasonic testing techniques.
\end{abstract}

Keywords: nondestructive testing; ultrasonic testing of welds; phased array technique

\section{Wstęp}

Badania złączy spawanych ultradźwiękową techniką phased array zostały znormalizowane zarówno w aspekcie wykonawstwa, jak i oceny wyników badań. Zasady stosowania badań phased array $\mathrm{w}$ odniesieniu do złączy spawanych o grubości równej lub większej od $6 \mathrm{~mm}$ opisano w PN-EN ISO 13588 wydanej w 2013 r. [2,5]. Jednakże mimo upływu kilku lat od wprowadzenia tejże normy, stopień wdrożenia badań phased array do polskiego przemysłu jest niewielki w stosunku do zalet i możliwości badawczych, jakie stwarza ta technika badań ultradźwiękowych. Od wielu lat zauważalny jest wzrost stosowania konwencjonalnych badań ultradźwiękowych, jednakże nie towarzyszył mu dotychczas analogiczny wzrost stosowania badań phased array, mimo że mogą one $z$ powodzeniem zastąpić je w większości zastosowań dotyczących badania złączy spawanych. Rezygnacja z badań konwencjonalnych na rzecz techniki phased array nie tylko zwiększa prawdopodobieństwo wykrycia nieciągłości, ale również zwiększa wiarygodność badania, między innymi dzięki zapisowi "surowych" wyników badań, jakimi są pliki danych z defektoskopu. Stanowią one obiektywny obraz wskazań uzyskanych w badanym złączu spawanym, zawierający zarówno wskazania istotne (pochodzące od nieciągłości), jak i wskazania pochodzące od geometrii badanego złącza [1]. Obserwacja wskazań na graficznych zobrazowaniach daje znacznie większe możliwości szybkiej i poprawnej identyfikacji i klasyfikacji wskazań fałszywych, których interpretacja jest największym problemem w badaniach konwencjonalnych. Ponadto, dzięki zapisowi wszystkich danych możliwa jest wielokrotna weryfikacja poprawności wyników kontroli badanego złącza, bez potrzeby powtórnego wykonania badań.

Istnieje wiele czynników wpływających na dotychczasowy niewielki wzrost zastosowań techniki phased array w Polsce. Są nimi między innymi duża złożoność systemów badań i związane z tym znacznie większe wymagania w zakresie kompetencji niezbędnych do prawidłowego zaplanowania strategii badań oraz dokonania ustawień i kalibracji systemu, które to czynności zgodnie z PN-EN ISO 13588 muszą być wykonywane na podstawie pisemnej procedury badania, a ich skuteczności musi być weryfikowana przy pomocy specjalnie wykonanych próbek odniesienia. Ponadto dużym ograniczeniem, zwłaszcza dla mniejszych laboratoriów, były dotychczas koszty wyposażenia do badań phased array, kilkukrotnie przekraczające ceny zestawów do badań konwencjonalnych.

Mgr inż. Rafał Kaczmarek - Politechnika Częstochowska, dr inż. Karol Kaczmarek - Instytut Spawalnictwa.

Autor korespondencyjny/Corresponding author. rafal.kaczmarek133@gmail.com 
Jednak kluczowym czynnikiem ograniczającym szybkość procesu wdrażania techniki phased array jest z pewnością niewystarczająca znajomość tej techniki w środowisku personelu NDT, spawalników, inspektorów nadzoru czy klientów laboratoriów badawczych. Naturalnym jest, iż znacznie chętniej są stosowane metody dobrze znane i ugruntowane w przemyśle, takie jak badania radiograficzne czy konwencjonalne badania ultradźwiękowe. W przypadku chęci zastąpienia ich innowacyjnymi technikami badań często występuje duża nieufność w stosunku do nowej, skomplikowanej techniki badawczej, dotychczas rzadko stosowanej w polskim przemyśle. Fakt ten pogłębiał brak przepisów normatywnych regulujących kwestię poziomów akceptacji dla złączy spawanych, który wymuszał opracowanie i przyjęcie, na podstawie uzgodnienia między stronami umowy, kryteriów akceptacji dla danego zadania badawczego. Nie zawsze jednak strony umowy były skłonne do zaakceptowania tego rozwiązania.

Z tego względu ukazanie się w drugiej połowie 2017 roku PN-EN ISO 19285 dotyczącej kryteriów oceny znacznie ułatwiło proces wdrażania badań phased array [6]. Norma ta odnosi się do oceny wskazań sklasyfikowanych zgodnie z PN-EN ISO 13588 i wprowadza poziomy akceptacji dedykowane dla odpowiednich poziomów jakości złączy spawanych. Zaproponowane poziomy akceptacji i ich korelacja z odpowiednimi poziomami jakości została także uwzględniona w najnowszym wydaniu PN-EN ISO 17635.

W pracy przedstawiono sposoby oceny wskazań wykrytych w badaniach złączy spawanych techniką phased array na podstawie PN-EN ISO 19285. Ma ona na celu zapoznanie Czytelników z oceną wskazań zaproponowaną w wyżej wymienionej normie międzynarodowej i tym samym, ułatwienie procesu wdrażania badań phased array do kontroli jakości złączy spawanych.

\section{Poziomy akceptacji wg PN-EN ISO 19285}

W normie PN-EN ISO 19285 określono trzy poziomy akceptacji. Korelacje między poziomami jakości, poziomami badania i poziomami akceptacji przedstawiono w tablicy I.

Dla poziomów akceptacji 2 i 3 może być stosowany jeden z dwóch, równorzędnych sposobów oceny wskazań:

- na podstawie długości i wysokości wskazań,

- na podstawie długości i amplitudy wskazań.

Pierwszy sposób, oparty na długości i wysokości wskazań, jest analogiczny do oceny stosowanej w badaniach techniką TOFD na podstawie PN-EN ISO 15626 [7]. Polega on na pomiarze i porównaniu wysokości wykrytych wskazań z wymiarem dopuszczalnym, a następnie na określeniu skumulowanej długości wskazań akceptowalnych, a także sumy wskazań punktowych na określonym odcinku złącza.

Tablica I. Poziomy akceptacji dla techniki Phased Array Table I. Acceptance levels for the Phased Array technique

\begin{tabular}{|c|c|c|}
\hline $\begin{array}{c}\text { Poziom jakości } \\
\text { zgodnie z ISO 5817 }\end{array}$ & $\begin{array}{c}\text { Poziom } \\
\text { badania zgodnie } \\
\text { z ISO 13588 }\end{array}$ & $\begin{array}{c}\text { Poziom } \\
\text { akceptacji }\end{array}$ \\
\hline C, D & A & 3 \\
\hline B & B & 2 \\
\hline według uzgodnienia & C & 1 \\
\hline zastosowania specjalne & D & $\begin{array}{c}\text { według } \\
\text { uzgodnienia }\end{array}$ \\
\hline
\end{tabular}

Kryteria akceptacji dla poziomu akceptacji 1 są określone wyłącznie dla oceny bazującej na długości i wysokości
W przypadku drugiego sposobu, opartego na długości i maksymalnej amplitudzie wskazań, ocena jest analogiczna do tej, która jest stosowana w konwencjonalnych badaniach ultradźwiękowych na podstawie PN-EN ISO 11666 [8]. W pierwszym kroku amplitudy poszczególnych wskazań przyrównywane są do dopuszczalnej wartości granicznej (w decybelach), których wartość jest uzależniona od długości wskazania. W kolejnym etapie obliczana jest skumulowana długość wskazań akceptowalnych na określonym odcinku złącza, która nie może przekroczyć dopuszczalnej wartości granicznej.

Poniżej szczegółowo przedstawiono obydwa sposoby oceny wskazań.

\section{Kryteria akceptacji bazujące na długości i wysokości}

W przypadku stosowania kryteriów wymiarowych po identyfikacji wskazań istotnych pierwszym etapem oceny jest ich klasyfikacja, mająca wspólne elementy z klasyfikacją stosowaną w badaniach TOFD [4]. Wskazania powinny być sklasyfikowane jako:

- wskazanie wychodzące na powierzchnię,

- wskazanie wewnętrzne,

- wskazanie punktowe.

Wskazania wewnętrzne oraz wychodzące na powierzchnię są wymiarowane przy pomocy kursorów pomiarowych. Zgodnie z PN-EN ISO 19285 wysokość wskazania powinna być wymiarowana przy pomocy sygnałów dyfrakcyjnych, jeśli takowe występują. Przykład wymiarowania wysokości pęknięcia z użyciem sygnałów dyfrakcyjnych pokazano na rysunku 1.

Jeśli wysokość nie może zostać zmierzona przy użyciu sygnałów dyfrakcyjnych, wówczas powinna ona zostać wyznaczona „w oparciu o amplitudę z użyciem poziomu odniesienia jak opisano w ISO 11666" [6]. Stwierdzenie to sugeruje użycie techniki ustalonego poziomu amplitudy w stosunku do poziomu oceny, służącego do wymiarowania długości wskazań. Jednakże norma pozostawia możliwość użycia innych technik wymiarowania, np. spadku $6 \mathrm{~dB}$. Rozwiązanie to wydaje się korzystniejsze z punktu widzenia dokładności wymiarowania wysokości wskazań, gdyż jest powiązane z maksymalną amplitudą wskazania, a błąd wynikający z szerokości wiązki dla mocno zogniskowanych głowic phased array jest niewielki. Ponadto, w większości dotychczasowych zastosowań techniki phased array na świecie stosowana jest technika spadku $6 \mathrm{~dB}$. Przykład wymiarowania wskazania niewykazującego sygnałów dyfrakcyjnych pokazano na rysunku 2.

Kolejnym etapem wymiarowania wskazań jest określenie ich długości. W punkcie 7.2 PN-EN ISO 19285 czytamy: „długość wskazania powinna być zmierzona jak opisano w ISO 11666, z użyciem wiązki, która zapewnia maksymalną amplitudę". Jest to więc ponowne odniesienie do techniki ustalonego poziomu amplitudy, która jest rekomendowana w ISO 11666 do wymiarowania długości wskazań. Polega ona na pomiarze odcinka, na którym amplituda wskazania osiąga lub przekracza ustalony poziom oceny. Zatem nasuwa się pytanie, czy zapis ten wskazuje tylko na technikę wymiarowania, czy także nakazuje użycie poziomu oceny takiego, jaki został określony w ISO 11666? Zdaniem autorów, druga interpretacja jest niewłaściwa, gdyż staje w sprzeczności z nakazem wymiarowania wysokości przy użyciu sygnałów dyfrakcyjnych. Sygnały te mają znacznie niższą amplitudę od sygnałów odbitych kierunkowo od nieciągłości, stąd też ich amplituda często spada poniżej poziomu oceny 


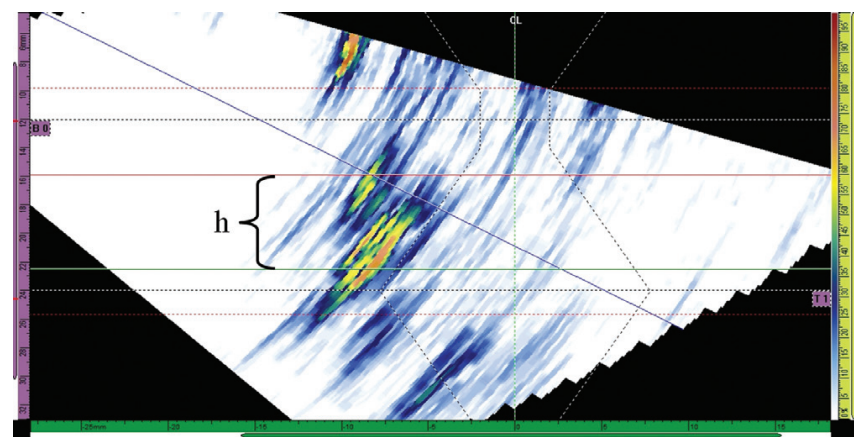

Rys. 1. Wymiarowanie wysokości h wskazania od pęknięcia usytuowanego w strefie wpływu ciepła złącza o grubości $12 \mathrm{~mm}$ przy użyciu sygnałów dyfrakcyjnych

Fig. 1. Dimensioning of the height $h$ of the indication from the crack located in the heat affected zone of the joint with a thickness of $12 \mathrm{~mm}$ using diffraction signals

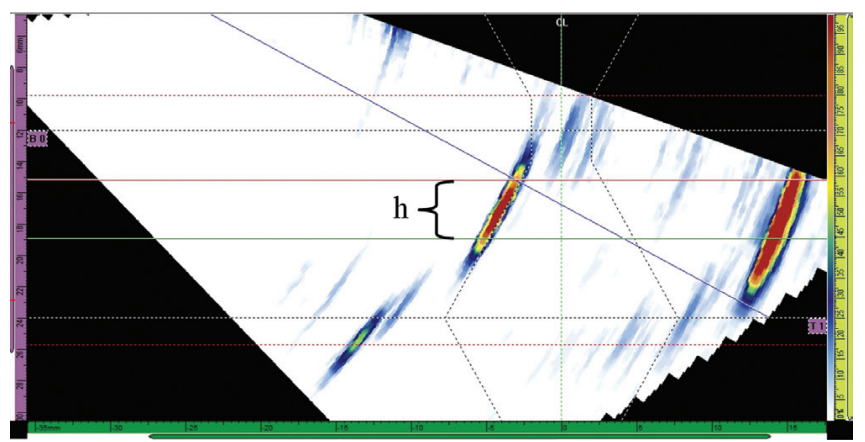

Rys. 2. Wymiarowanie spadkiem $6 \mathrm{~dB}$ wysokości h wskazania od przyklejenia brzegowego w złączu spawanym o grubości $12 \mathrm{~mm}$ Fig. 2. Dimensioning with $6 \mathrm{~dB}$ drop in the height h of the indication from edge sticking in a $12 \mathrm{~mm}$ thick welded joint

opisanego w ISO 11666 (np. $\mathrm{H}_{0}-14$ dB dla techniki 1 nastawiania poziomu odniesienia, gdzie $\mathrm{H}_{0}$ oznacza poziom odniesienia w postaci krzywej DAC od otworu cylindrycznego o średnicy $3 \mathrm{~mm}$ ). Prowadziłoby to do wyznaczenia wysokości wskazania przy pomocy sygnałów dyfrakcyjnych, którego długość wynosiłaby jednak zero ze względu na niewielką amplitudę tychże sygnałów, niższą od przyjętego poziomu oceny. Ponadto narzucenie poziomu oceny z badań konwencjonalnych jednocześnie eliminuje możliwość oceny wskazań od gniazd pęcherzy, które są wyraźnie widoczne na zobrazowaniach phased array, a których amplituda ze względu na duże rozproszenie wiązki jest zazwyczaj kilka decybeli poniżej poziomu oceny z badań konwencjonalnych. Adekwatny przykład pokazano na rysunku 3 przedstawiającym zobrazowanie typu S z miejsca występowania gniazda pęcherzy. Maksymalna amplituda wskazania wynosi $\mathrm{H}_{0}-15,7 \mathrm{~dB}$, podczas gdy poziom oceny zgodny z ISO 11666

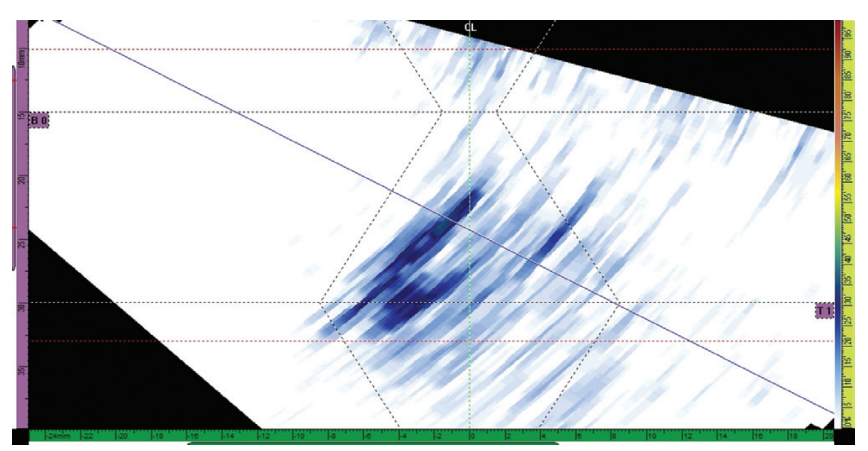

Rys. 3. Przykład dużego gniazda pęcherzy w złączu spawanym o grubości $15 \mathrm{~mm}$ o maksymalnej amplitudzie $\mathrm{H}_{0}-15,7 \mathrm{~dB}$

Fig. 3. An example of a large localized porosity in a $15 \mathrm{~mm}$ thick welded joint with a maximum amplitude of $\mathrm{H}_{0}-15,7 \mathrm{~dB}$ to $\mathrm{H}_{0}-14 \mathrm{~dB}$. W przypadku przyjęcia poziomu oceny $\mathrm{H}_{0}-14 \mathrm{~dB}$, wskazanie to nie będzie oceniane, pomimo że jest doskonale widoczne na zobrazowaniu. Należy nadmienić, że w badaniach RT to gniazdo pęcherzy jest nieakceptowane.

Stąd też, przyjęcie poziomu oceny z badań konwencjonalnych $w$ technice phased array nie powinno być stosowane, gdyż eliminuje możliwość oceny niektórych wskazań skutecznie wykrytych tą techniką badań (np. gniazda pęcherzy czy nieciągłości płaskie prostopadłe do powierzchni wykazujące wyłącznie sygnały dyfrakcyjne o niskiej amplitudzie z wierzchołków nieciągłości itd.). Z powyższych rozważań wynika, iż niniejszy zapis normy odwołujący się do ISO 11666 jest nieprecyzyjny i w kolejnych wydaniach powinien zostać uściślony, aby nie budził w przyszłości wątpliwości co do jego interpretacji.

W przypadku, gdy wskazania są zlokalizowane w niedalekiej odległości od siebie mogą podlegać grupowaniu. Następuje ono, gdy są spełnione jednocześnie dwa warunki:

- odległość pomiędzy dwoma indywidualnymi wskazaniami wzdłuż złącza jest mniejsza niż długość dłuższego ze wskazań,

- odległość pomiędzy dwoma indywidualnymi wskazaniami w kierunku grubości złącza ma wartość mniejszą niż wysokość wyższego ze wskazań.

Długość tak utworzonej grupy nie może służyć do dalszego grupowania. Grupowaniu nie podlegają wskazania punktowe.

Warto zauważyć, że powyższy sposób grupowania został zaczerpnięty wprost z normy ISO 15626 dotyczącej oceny wskazań w TOFD. Stąd też nie występuje w nim trzeci warunek grupowania, odnoszący się do odległości pomiędzy wskazaniami w kierunku szerokości spoiny (tzn. w kierunku osi y). Jest to niezrozumiałe, gdyż - w przeciwieństwie do TOFD - w przypadku techniki phased array możliwe jest wyznaczenie lokalizacji wskazań w tymże kierunku. Z tego względu nieuzasadnione jest grupowanie dwóch wskazań, których odległość w kierunku szerokości spoiny wynosi kilkanaście lub kilkadziesiąt milimetrów (np. wskazania od niewielkich nieciągłości, usytuowane na dwóch, przeciwległych ściankach rowka spawalniczego w złączu o dużej grubości). Z kolei zgodnie z amplitudowymi kryteriami akceptacji zawartymi w PN-EN ISO 19285 i omówionymi w dalszej części artykułu, wskazania takie nie są grupowane.

Po wyznaczeniu długości i wysokości wskazań (lub grupy wskazań) oraz określeniu ich klasyfikacji (wychodzące na powierzchnię, wewnętrzne) następuje przyrównanie uzyskanych wartości z wartościami granicznymi dla danego poziomu akceptacji. W tablicy II zawarto wymiarowe kryteria akceptacji dla poziomu akceptacji 2 wymaganego dla poziomu jakości B. O akceptacji wskazania decyduje wysokość, długość i rodzaj wskazania. Jak widzimy, zgodnie z regułami mechaniki pękania bardziej rygorystycznie traktowane są wskazania o większej długości oraz wychodzące na powierzchnię. Na przykład, dla grubości złącza równej $16 \mathrm{~mm}$ wskazania wewnętrzne o długości nieprzekraczającej $16 \mathrm{~mm}$ są akceptowalne do wysokości $4 \mathrm{~mm}$, natomiast wychodzące na powierzchnię do $2 \mathrm{~mm}$. Wskazania o długości powyżej $16 \mathrm{~mm}$ są akceptowalne jedynie do wysokości $1 \mathrm{~mm}$ (zarówno wewnętrzne, jak i wychodzące na powierzchnię).

Jeżeli wszystkie wykryte wskazania są akceptowalne, wówczas dokonuje się wyznaczenia skumulowanej długości wszystkich indywidualnie akceptowalnych wskazań na określonym odcinku złącza (nie wlicza się wskazań punktowych). Długość odcinka, na którym należy zsumować wskazania, zależy od grubości złącza. Na przykład, dla grubości $t \leq 50$ $\mathrm{mm}$ jego długość wynosi 12t. Skumulowana długość wskazań na tak wyznaczonym odcinku nie może przekroczyć granicznej wartości, określonej dla danego poziomu akceptacji. (Na przykład dla zakresu grubości $\mathrm{t} \leq 50 \mathrm{~mm}$ i poziomu 
Tablica II. Kryteria akceptacji dla poziomu akceptacji 2

Table II. Acceptance criteria for acceptance level 2

\begin{tabular}{|c|c|c|c|c|}
\hline \multirow[b]{2}{*}{ Zakres grubości } & \multicolumn{3}{|c|}{$\begin{array}{l}\left.\text { Maksymalna dopuszczalna długość ( } I_{\max }\right) \\
\text { jeśli } \mathrm{h}<\mathrm{h} 2 \text { lub h3 }\end{array}$} & \multirow{2}{*}{$\begin{array}{c}\text { Maksymalna } \\
\text { dopuszczalna wysokość } \\
\text { (h1) gdy I > I } I_{\max } \\
\text { h1 [mm] }\end{array}$} \\
\hline & $I_{\max }[\mathrm{mm}]$ & $\begin{array}{c}\text { wychodzące } \\
\text { na powierzchnię } \\
\text { h3 }[\mathrm{mm}]\end{array}$ & $\begin{array}{c}\text { wewnętrzne } \\
\text { h2 [mm] }\end{array}$ & \\
\hline $6 \mathrm{~mm}<\mathrm{t} \leq 15 \mathrm{~mm}$ & $\mathrm{t}$ & 2 & 2 & 1 \\
\hline $15 \mathrm{~mm}<\mathrm{t} \leq 50 \mathrm{~mm}$ & $\mathrm{t}$ & 2 & 4 & 1 \\
\hline $50 \mathrm{~mm}<\mathrm{t} \leq 100 \mathrm{~mm}$ & 50 & 3 & 5 & 2 \\
\hline $\mathrm{t}>100 \mathrm{~mm}$ & 60 & 4 & 6 & 3 \\
\hline
\end{tabular}

akceptacji 2 wartość ta wynosi 4t). W przypadku złącza o grubości t = $16 \mathrm{~mm}$, dla którego wymagany jest poziom akceptacji 2, dopuszczalna skumulowana długość wszystkich indywidualnie akceptowalnych wskazań na odcinku o długości $192 \mathrm{~mm}$ wynosi $64 \mathrm{~mm}$.

Ostatnim etapem oceny jest obliczenie ilości wskazań punktowych na odcinku o długości $150 \mathrm{~mm}$ (dla wszystkich grubości). Ilość wskazań punktowych nie może przekroczyć wartości 1,2t. Tak więc, dla złącza o grubości t $=16 \mathrm{~mm}$ na odcinku o długości $150 \mathrm{~mm}$ może występować maksymalnie 20 wskazań punktowych. Wskazania punktowe w PN-EN ISO 19285 są zdefiniowane jako wskazania nieposiadające znaczącego rozmiaru w żadnym z kierunków. Z tego względu w procedurze badania powinny zostać zawarte precyzyjne wytyczne określające zasady klasyfikacji wskazań punktowych. Powinny uwzględniać one szerokość wiązki ultradźwiękowej w kierunku długości i grubości badanego złącza, wynikającą z częstotliwości, wymiaru apertury, zastosowanego ogniskowania oraz odległości głowicy od osi spoiny. W procedurze badania powinien zostać również określony poziom rejestracji dotyczący wskazań punktowych.

\section{Kryteria akceptacji bazujące na długości i amplitudzie}

Drugi, równorzędny sposób oceny wskazań zaproponowany w PN-EN ISO 19285 jest zaczerpnięty z normy ISO 11666, dotyczącej oceny w konwencjonalnych badaniach ultradźwiękowych. Z tego względu o akceptowalności poszczególnych wskazań (lub grupy wskazań) decydują wyłącznie długość i maksymalna amplituda, a w dalszym etapie o akceptowalności całego złącza decyduje skumulowana długość wskazań akceptowalnych na określonym odcinku złącza. W tym przypadku nie występuje więc klasyfikacja wskazań, w której dokonuje się rozróżnienia na wskazania wychodzące na powierzchnię, wewnętrzne czy punktowe, jak miało to miejsce w przypadku wymiarowych kryteriów akceptacji. Kryteria amplitudowe opisano wyłącznie dla poziomów akceptacji 2 i 3 , ponadto mogą być one stosowane wyłącznie w zakresie grubości $8 \mathrm{~mm} \leq \mathrm{t}<100 \mathrm{~mm}$.

Długość wskazań jest określana poprzez pomiar odcinka wzdłuż spoiny, na którym amplituda wskazania utrzymuje się powyżej poziomu oceny, z zastosowaniem techniki ustalonego poziomu amplitudy, opisanej w załączniku B normy ISO 19285. Ponieważ poziomy odniesienia oraz poziomy oceny są tożsame z tymi, które są stosowane w badaniach konwencjonalnych, z tego względu nasuwają się tutaj te same wątpliwości, które opisano przy omawianiu pomiaru długości wskazań przy kryteriach wymiarowych. Duża część wskazań reprezentowana przez sygnały dyfrakcyjne lub sygnały odbite rozproszone (np. od gniazd pęcherzy), wykazuje amplitudę poniżej narzuconego poziomu oceny. Stąd też mogą być one wyraźnie widoczne na zobrazowaniach phased array, a mimo to nie będą oceniane z powodu niewielkiej amplitudy wskazań. Takowy sposób oceny prowadzi więc do niewykorzystania potencjału badań phased array.

Norma w odniesieniu do wyznaczania długości wskazań w przypadku stosowania kryteriów amplitudowych pozostawia możliwość zastosowania alternatywnych technik wymiarowania, jeśli takie zostały określone.

Prócz wyznaczenia długości wskazania należy także określić jego amplitudę w stosunku do poziomu odniesienia, nastawionego przy użyciu jednej z czterech technik (1 - otwory poprzeczne, 2 - otwory płaskodenne, 3 - rowek prostokątny, 4 - otwór płaskodenny dla techniki tandem).

Po wyznaczeniu długości i maksymalnej amplitudy wskazań wyznaczona wartość amplitudy zostaje przyrównana do poziomów rejestracji oraz poziomów akceptacji zgodnie z tabelą A1 zamieszczoną w aneksie A PN-EN ISO 19285. Przyjęte poziomy rejestracji i akceptacji są tożsame z zaproponowanymi w ISO 11666 dla badań konwencjonalnych. Dla złączy o grubości $8 \mathrm{~mm} \leq \mathrm{t}<15 \mathrm{~mm}$ wskazania są podzielone na dwie grupy, uzależnione od ich długości I $(\mathrm{I} \leq \mathrm{t}$ oraz $\mathrm{I}>\mathrm{t}$ ). W przypadku złączy o grubości $15 \mathrm{~mm} \leq \mathrm{t}<100 \mathrm{~mm}$ wskazania są podzielone na trzy grupy $(I \leq 0,5 t, 0,5 t<I \leq t$, I > t). O akceptowalności poszczególnych wskazań decyduje dopuszczalny poziom amplitudy przyjęty dla danej grupy wskazań. Zostanie on przedstawiony na przykładzie poziomu akceptacji 2, techniki 1 nastawiania poziomu odniesienia i zakresu grubości $15 \mathrm{~mm} \leq \mathrm{t}<100 \mathrm{~mm}$. Wskazania o długości $I \leq 0,5$ t są akceptowalne do amplitudy równej $\mathrm{H}_{0}$, wskazania o długości 0,5t < I $\leq \mathrm{t}$ są akceptowalne do amplitudy równej $\mathrm{H}_{0}-6 \mathrm{~dB}$, natomiast wskazania o długości I > t są akceptowalne do amplitudy równej $\mathrm{H}_{0}-10 \mathrm{~dB}$.

Wszystkie wskazania akceptowalne, których amplituda przekracza poziomy rejestracji a długość jest większa od wartości granicznej (tzn. t dla zakresu grubości $8 \mathrm{~mm}$ $\leq \mathrm{t}<15 \mathrm{~mm}$ oraz $\mathrm{t} / 2$ lub $20 \mathrm{~mm}$ dla grubości $\mathrm{t} \geq 15 \mathrm{~mm}$ ) powinny zostać poddane dalszym badaniom, z użyciem innego kąta padania wiązki lub techniki tandem. Wymaganie to, zaczerpnięte bezpośrednio z normy ISO 11666, jest bardzo kłopotliwe w przypadku badań automatycznych, w których ocena wskazań następuje niezależnie od skanowania złączy. Powoduje to potrzebę powrotu na miejsce wykonywania badań, ponownego zamontowania sprzętu (np. na rurociągu) i powtórnego badania złączy przy zastosowaniu alternatywnego planu skanowania (tzw. scan plan, gwarantujący inne kąty padania wiązki na wykryte wcześniej wskazanie). Z tego względu znacznie wygodniejszym i bardziej skutecznym sposobem wykonania badania uzupełniającego byłoby zastosowanie manualnych badań phased array na danym odcinku złącza, które umożliwiałoby uzyskanie maksymalnej amplitudy wskazania. Niestety tego rodzaju badanie nie zostało opisane w żadnej z norm EN lub ISO, 
stąd dodatkowe trudności w jego wdrożeniu. Alternatywą są konwencjonalne badania ultradźwiękowe, które jednakże ze względu na ograniczony wybór kątów głowic mogą w ogóle nie wykryć danego wskazania.

Wskazania akceptowalne leżące w bliskiej odległości od siebie powinny zostać zgrupowane dla celów oceny wówczas, jeśli są spełnione wszystkie trzy warunki:

- odległość pomiędzy wskazaniami w kierunku długości złącza jest mniejsza niż dwukrotna długość dłuższego wskazania,

- odległość pomiędzy wskazaniami w kierunku szerokości złącza jest mniejsza od połowy grubości, ale nie większa niż $10 \mathrm{~mm}$,

- odległość pomiędzy wskazaniami w kierunku grubości złącza jest mniejsza od połowy grubości, ale nie większa niż $10 \mathrm{~mm}$.
W przypadku, gdy wszystkie wskazania (zarówno pojedyncze, jak i zgrupowane) są akceptowalne, wówczas o akceptacji całego złącza decyduje skumulowana długość wszystkich indywidualnie akceptowalnych wskazań na odcinku o długości $I_{w}=6 t$. Warto zauważyć, że $-\mathrm{w}$ odróżnieniu od normy ISO 11666 - długość odcinka $I_{w}$ jest określona powyższym wzorem w całym zakresie grubości (w przywołanej normie wzór ten obowiązywał wyłącznie dla złączy o grubości poniżej $15 \mathrm{~mm}$ ). Na przykład, dla poziomu akceptacji 2 akceptowalna skumulowana długość wskazań na odcinku $I_{w}$ wynosi $20 \%$ długości tego odcinka.

\section{Analiza i wnioski}

Ukazanie się normy PN-EN ISO 19285 zawierającej kryteria akceptacji dla złączy spawanych badanych przy użyciu techniki phased array jest znacznym ułatwieniem w procesie wdrażania tych badań w polskiej praktyce przemysłowej. Powinno ono skutkować znacznym przyspieszeniem procesu zastępowania konwencjonalnych badań ultradźwiękowych innowacyjną i znacznie bardziej wiarygodną techniką phased array. W pierwszej kolejności należy wprowadzać technikę phased array do badań najbardziej odpowiedzialnych złączy tam, gdzie dąży się do wykrycia wszystkich nieakceptowanych nieciągłości i z tego względu stosowany jest 100\% zakres badań. Wówczas możliwość udokumentowania przeprowadzonej kontroli ultradźwiękowej w postaci zachowania plików danych z defektoskopu, a także możliwość wykonania powtórnej oceny wyników ma niebagatelne znaczenie. W przypadku długich złączy doczołowych, w których można zastosować większe skanery, optymalnym rozwiązaniem jest uzupełnienie badań phased array realizowaną symultanicznie techniką TOFD, która w niewielkim stopniu zwiększa pracochłonność badania, a jednocześnie ogranicza do minimum możliwość niewykrycia nieciągłości [3,4].

Pozytywny fakt, jakim jest pojawienie się PN-EN ISO 19285 nie może jednak przysłonić pewnych nasuwających się wątpliwości, związanych z przyjętą konstrukcją normy, będącej scaleniem norm ISO 15626 oraz ISO 11666 dotyczących kryteriów akceptacji w badaniach techniką TOFD oraz konwencjonalnych badaniach UT. Kryteria te zostały opracowane dla zupełnie odmiennych technik ultradźwiękowych, bazujących na innych sposobach detekcji wskazań (dyfrakcja w TOFD, odbicie z najwyższą możliwą do uzyskania amplitudą wskazania w konwencjonalnych badaniach ultradźwiękowych), jak i środkach wykorzystanych do tej detekcji (głowice szerokopasmowe o wysokich częstotliwościach i bardzo małych przetwornikach w TOFD, głowice konwencjonalne i wykorzystanie ich wiązki poza polem bliskim głowicy w warunkach braku silnych wahań ciśnienia akustycznego w UT). Stąd też przeniesienie kryteriów wymiarowych z TOFD oraz amplitudowych z UT do badań phased array jako kryteriów równoważnych może prowadzić do znaczących różnic w ocenie złączy, zależnej od techniki badania, przyjętych kryteriów (wymiarowych, amplitudowych) czy też zastosowanego wariantu badań PAUT (skan sektorowy, liniowy) oraz jego parametrów (zakres kątowy, pozycja głowicy, wielkość apertury, ogniskowanie itd.). Aby zobrazować możliwe skutki takiego systemu oceny na rysunku 4 i 5 przedstawiono wyniki badania fragmentu złącza o grubości 15 mm i kącie ukosowania $25^{\circ}$, wykonanego przy użyciu skanu sektorowego typu compound i techniki 1 nastawiania poziomu odniesienia (DAC, $\varnothing 3 \mathrm{~mm}$ ). Badania zostały wykonane przy identycznych ustawieniach wiązki i nastawach czułości. Jedyną różnicą było usytuowanie głowicy; odległość czoła głowicy od osi spoiny w pierwszym badaniu wynosiła 16 mm, natomiast w drugim $33 \mathrm{~mm}$. W pierwszym badaniu kąt wiązki padającej na przyklejenie wynosi $57^{\circ}$ i umożliwia uzyskanie maksymalnej amplitudy równej $\mathrm{H}_{0}-12 \mathrm{~dB}$. W drugim przypadku przyklejenie jest wykrywane wiązką o kącie $65^{\circ}$, zapewniającą prostopadłe

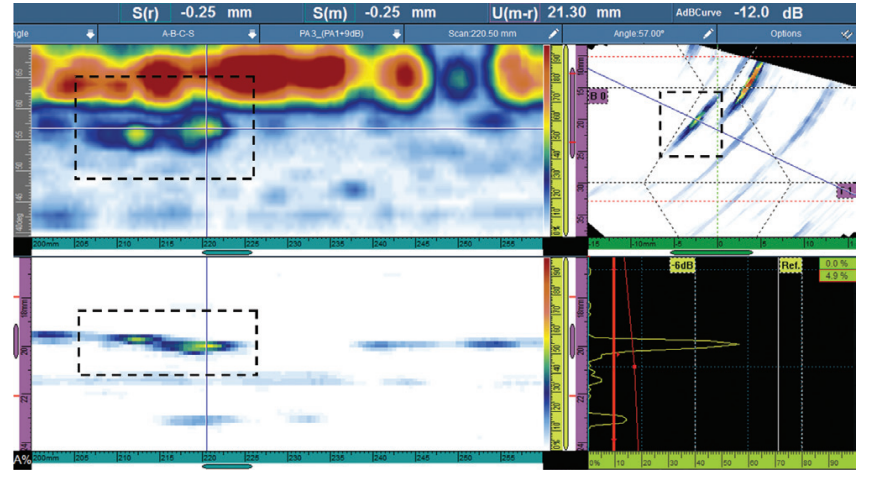

Rys. 4. Wskazanie przyklejenia brzegowego o maksymalnej amplitudzie równej $\mathrm{H}_{0}-12,0 \mathrm{~dB}$ uzyskanej wiązką o kącie $57^{\circ}$ (skan sektorowy typu compound, odległość głowicy od osi spoiny $16 \mathrm{~mm}$ ) Fig. 4. Indication of edge sticking with a maximum amplitude equal to $\mathrm{H}_{0}-12.0 \mathrm{~dB}$ obtained with a beam of $57^{\circ}$ angle (sectoral scan of compound type, distance of the head from the axis of the weld $16 \mathrm{~mm}$ )

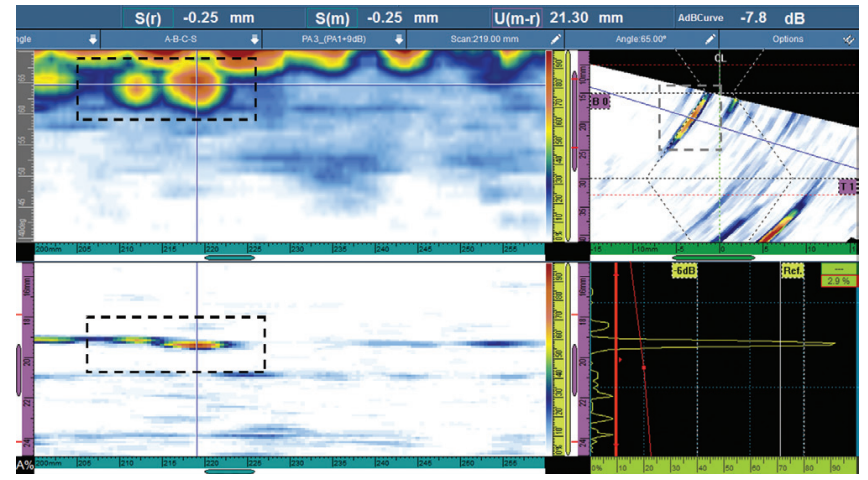

Rys. 5. Wskazanie przyklejenia brzegowego z rysunku 4 o maksymalnej amplitudzie równej $\mathrm{H}_{0}-7,8 \mathrm{~dB}$ uzyskanej wiązką o kącie $65^{\circ}$ (skan sektorowy typu compound, odległość głowicy od osi spoiny $33 \mathrm{~mm}$ ) Fig. 5. Indication of edge sticking from figure 4 with maximum amplitude equal to $\mathrm{H}_{0}-7.8 \mathrm{~dB}$ obtained with a beam of $65^{\circ}$ angle (sectoral scan of compound type, distance of the head from the axis of the weld $33 \mathrm{~mm}$ ) 
padanie wiązki na ściankę rowka spawalniczego, stąd też wyższa amplituda wskazania wynosząca $\mathrm{H}_{0}-7,8 \mathrm{~dB}$. Stąd wniosek, że przy ocenie bazującej na amplitudzie i długości wskazań nawet niewielkie zmiany kąta padania wiązki na nieciągłość wynikające między innymi z odległości głowicy od osi spoiny mogą prowadzić do kilkudecybelowych zmian amplitudy, która może diametralnie zmienić ocenę danego wskazania (akceptacja / brak akceptacji lub rejestracja / brak rejestracji).

Przykład ten obrazuje fakt, że zaczerpnięcie kryteriów akceptacji z badań konwencjonalnych nie jest dobrym rozwiązaniem w odniesieniu do badań phased array z użyciem skanu sektorowego przy zachowaniu stałej odległości głowicy od osi spoiny. Stosowanie kryteriów amplitudowych jest zasadne w przypadku:

- manualnych badań phased array z użyciem skanu sektorowego oraz badań automatycznych z zastosowaniem mechanicznego skanowania rastrowego, w których możliwe jest, poprzez odpowiednie odsunięcie głowicy od spoiny, znalezienie maksymalnej amplitudy wskazania,

- badań phased array z użyciem skanu liniowego, z kątem dopasowanym do kąta ukosowania spoiny, adekwatnie do badań konwencjonalnych,

- badań phased array, w których stosowane są ustalone kąty wprowadzenia wiązki, kierowane w ściśle określone obszary spoiny a czułość poszczególnych wiązek skalowana jest niezależnie.

W tych przypadkach wyniki badań phased array będą porównywalne a amplitudy wskazań będą zbliżone do tych, które uzyskiwane byłyby w badaniach konwencjonalnych.

W pozostałych przypadkach, takich jak najbardziej rozpowszechnione i najkorzystniejsze z praktycznego punktu widzenia badanie z użyciem skanu sektorowego przy stałej odległości głowicy od osi spoiny, może dochodzić do znaczących rozbieżności między oceną tych samych fragmentów złączy spawanych. Ponadto może wystąpić silne zróżnicowanie oceny nieciągłości, w szczególności płaskich, w zależności od ich usytuowania na głębokości złącza. W opinii autorów, w takich przypadkach powinny być stosowane kryteria oparte na długości i wysokości wskazań, z odpowiednio dopasowanym poziomem oceny. Zastosowanie tutaj poziomów oceny z badań konwencjonalnych prowadziłoby do pominięcia wielu wyraźnie widocznych, łatwych do interpretacji wskazań o niskiej amplitudzie. Poprawnie określony poziom oceny powinien być dopasowany do amplitudy wskazań dyfrakcyjnych, zwłaszcza w przypadku badania grubych złączy, dla których niemożliwe jest zapewnienie korzystnego, prostopadłego padania wiązek na powierzchnię ścianki rowka spawalniczego, w pobliżu której występuje największa ilość najniebezpieczniejszych nieciągłości (przyklejenia brzegowe oraz pęknięcia).

W PN-EN ISO 19285 niestety nie sprecyzowano warunków, przy zachowaniu których mogą być stosowane kryteria wymiarowe, czy też amplitudowe. Całkowity ciężar doboru parametrów badania oraz wyboru stosowanych kryteriów akceptacji został zatem przeniesiony na procedurę badania, wymaganą zgodnie z PN-EN ISO 13588 we wszystkich poziomach badania (A, B, C i D). Obowiązek prawidłowego zaplanowania strategii badania wraz z doborem kryteriów akceptacji oraz wykazaniem ich skuteczności spoczywa więc na personelu III stopnia, który opracowuje procedury badań techniką phased array.

\section{Literatura}

[1] Kaczmarek R.: Problematyka wskazań od geometrii w konwencjonalnych badaniach ultradźwiękowych oraz badaniach Phased Array, Biuletyn Instytutu Spawalnictwa, nr 2, 2017.

[2] Mackiewicz S.: Badania złączy spawanych techniką phased array w świetle wymagań PN-EN ISO 13588, Przegląd Spawalnictwa, Vol. 87, nr 12, 2015.

[3] Kaczmarek R., Kaczmarek K., Słania J.: Zalety symultanicznych badań ultradźwiękowych techniką Phased Array i TOFD złączy spawanych, Przegląd Spawalnictwa, Vol. 89, nr 4, 2017.

[4] Kaczmarek R., Kaczmarek K., Słania J., Krawczyk R.: Wykonywanie badań ultradźwiękowych techniką TOFD w aspekcie wymagań norm przedmiotowych, Biuletyn Instytutu Spawalnictwa, nr 4, 2016.

[5] PN-EN ISO 13588 Badania nieniszczące spoin - Badania ultradźwiękowe - Stosowanie technologii zautomatyzowanej głowicy mozaikowej

[6] PN-EN ISO 19285 Badania nieniszczące spoin - Badania ultradźwiękowe techniką głowicy mozaikowej (PAUT) - Kryteria akceptacji

[7] PN-EN ISO 15626 Badanie nieniszczące spoin - Technika czasu przejścia wiązki dyfrakcyjnej (TOFD) - Poziomy akceptacji

[8] PN-EN ISO 11666 Badania nieniszczące spoin - Badania ultradźwiękowe - Poziomy akceptacji 


\title{
Wpływ obróbki powierzchni przy użyciu zimnej plazmy na przyczepność powłoki galwanicznej do kompozytu grafitowego i jej przydatność w procesach lutowania miękkiego
}

\author{
The influence of cold plasma-surface modification on the grip \\ of the electroplating finish to graphite composite \\ and for its usefulness in soldering processes
}

\section{Streszczenie}

W artykule przedstawiono problematykę dotyczącą przygotowania powierzchni kompozytu grafitowego przed nałożeniem galwanicznej powłoki miedzianej i jej wpływ na proces lutowania miękkiego w połączeniach z materiałami metalicznymi. Na próbki z kompozytu grafitowego, którego powierzchnię przygotowano różnymi metodami, oraz w końcowej obróbce przy użyciu zimnej plazmy, wytworzonej w atmosferze argonu, naniesiono galwanicznie warstwę miedzi, a następnie wykonano badania przyczepności powłoki do podłoża. Wyniki te porównano z wcześniej przeprowadzonymi pomiarami wytrzymałościowymi złączy kompozytu z naniesioną powłoką miedzianą, lutowanych na miękko z elementami ze stopu aluminium PA38 (6060).

Słowa kluczowe: kompozyt grafitowy; lutowanie miękkie; powłoki galwaniczne; zimna plazma

\begin{abstract}
In the article issues concerning preparing the surface of graphite composite before putting the galvanic copper layer and its influence on the soldering process were described in connections with metallic materials. To samples of graphite composite, of which the area was prepared with different methods, and in final processing using cold plasma, produced in the atmosphere of argon, galvanic a layer of copper was put, and then a research on the grip of the layer was performed to base material. The results were compared with earlier conducted endurance measurements of connectors of composite with the copper layer, soldered on softly with elements of the alloy of PA38 aluminium (6060).
\end{abstract}

Keywords: graphite composite; soldering; galvanic coats; cold plasma

\begin{abstract}
Wstęp
Spajanie materiałów takich, jak ceramika, grafit i materiały kompozytowe na osnowie grafitu stanowi zwykle duży problem technologiczny. Połączenia te są zwykle wykonywane poprzez procesy lutowania wysokotemperaturowego w próżni, w których decydujący wpływ mają zjawiska o charakterze dyfuzyjnym [6]. Obserwując liczne doniesienia literaturowe mówiące o wpływie obróbki zimną plazmą na stan i aktywność powierzchni materiałów [3,7,8,11], które zostały przygotowane przy użyciu tej technologii, można przypuszczać, że może ona poprawić powierzchnię także dla potrzeb nakładania powłok galwanicznych. Połączenia materiałów wytworzonych na osnowie grafitu $z$ aluminium i jego stopami znajdują zastosowanie w urządzeniach przewodzących prąd elektryczny, dlatego też złącza muszą cechować się odpowiednią przewodnością
\end{abstract}

elektryczną i wytrzymałością mechaniczną. Dobrą przewodność elektryczną można uzyskać stosując połączenie metaliczne uzyskane w procesie lutowania miękkiego. Lutowanie grafitu w sposób bezpośredni jest jednak niemożliwe do wykonania z uwagi na brak jego zwilżalności lutami miękkimi $[9,10]$.

\section{Materiały użyte do badań}

W badaniach zastosowano materiał kompozytowy na bazie koksu pakowego z dodatkiem grafitu (spełniającego funkcję smaru) i $40 \%$ wag. ziaren Cu jako napełniacza, sklejonych żywicą wypaloną do węgla szklistego, dostarczonego przez firmę Carbo-Graf Sp. z o.o., z Raciborza.

Dr hab. inż. Zbigniew Zimniak, prof. PWr; prof. dr hab. inż. Zbigniew Mirski; mgr inż. Ireneusz Ciepacz; dr hab. inż. Kazimierz Granat prof. PWr; dr inż. Tomasz Wojdat - Politechnika Wrocławska.

Autor korespondencyjny/Corresponding author: zbigniew.zimniak@pwr.edu.pl 
Wyżej wymieniony materiał poddano obróbce przygotowania powierzchni, nałożono warstwę powłoki galwanicznej miedzianej, a następnie poddano badaniom przyczepności powłoki do podłoża metodą „pull-off” przy użyciu testera ELCOMETER 510, wg normy PN-EN ISO 4624:2004.

\section{Zakres badań}

Zrealizowano następujący zakres badań:

a) przygotowanie powierzchni materiału kompozytowego:

- odtłuszczanie ultradźwiękowe,

- aktywacja w bezwodniku chromowym;

b) pomiary zwilżalności powierzchni kompozytu grafitowego po każdym ze sposobów przygotowania powierzchni;

c) pomiary chropowatości powierzchni kompozytu grafitowego przed nałożeniem powłoki galwanicznej;

d) wstępne zarysowanie powierzchni przed nałożeniem warstwy galwanicznej za pomocy głowicy $10 \mathrm{~mm}$ testera ELCOMETER 510 [2];

e) obróbka powierzchni przy użyciu zimnej plazmy;

f) naniesienie galwanicznej powłoki miedzianej na kompozyt grafitowy;

g) pomiary przyczepności powłoki galwanicznej do powierzchni kompozytu grafitowego metodą zrywania powłoki (metoda pull-off);

h) opracowanie wyników i wnioski.

Przygotowanie powierzchni materiałów przed nałożeniem powłoki galwanicznej ma zasadnicze znaczenie dla jej przyczepności do podłoża, a w przypadku powłok stanowiących warstwy pośrednie w połączeniach lutowanych ważne też jest znaczne rozwinięcie powierzchni oraz usunięcie wszelkiego rodzaju pozostałości po obróbce strumieniowościernej. Do badań wytypowano następujące sposoby przygotowania powierzchni:

- obróbka szlifierska,

- obróbka strumieniowo-ścierna,

- obróbka chemiczna,

- obróbka przy użyciu zimnej plazmy w atmosferze argonu wcześniej przygotowanych podłoży.

\section{Przygotowanie powierzchni materiału kompozytowego}

Szlifowanie próbek przeprowadzono przy użyciu papieru ściernego o gradacji 180. Obróbkę strumieniowo-ścierną zrealizowano przy użyciu korundu o gradacji 30. Po obróbce
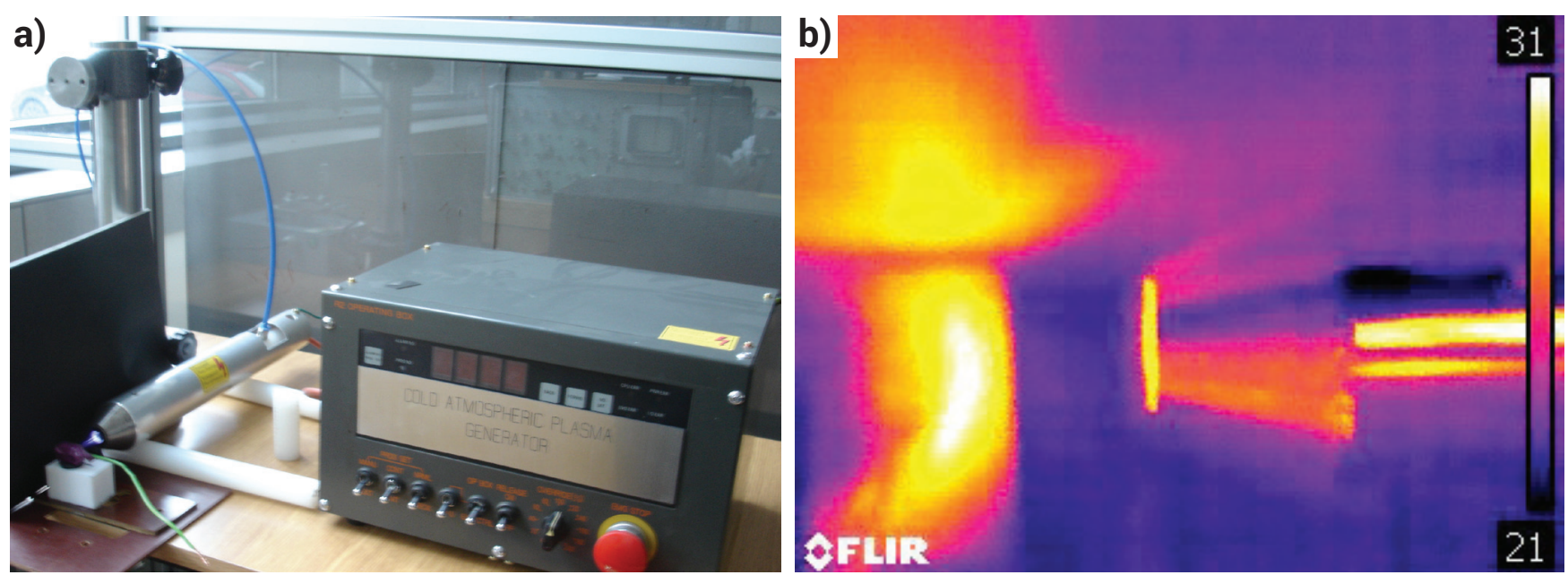

Rys. 1. Obróbka materiału kompozytowego przy użyciu zimnej plazmy: a) widok ogólny, b) pomiar temperatury plazmy kamerą termowizyjną Fig. 1. Treatment of a composite material using a cold plasma: a) general view, b) plasma temperature measurement with a thermal imager 
gdzie było to możliwe przy zastosowaniu analizatora energii powierzchni KRUSS DS. AHT-12 z oprogramowaniem HTM firmy Reetz GmbH (rys. 2).

Badania przy użyciu analizatora ATH12 firmy KRUSS możliwe były do wykonania tylko dla próbek szlifowanych i potwierdziły one wyniki testu kroplowego. Jedynie dla obróbki strumieniowo-ściernej z oddziaływaniem plazmy uzyskano zwilżanie w każdym teście.

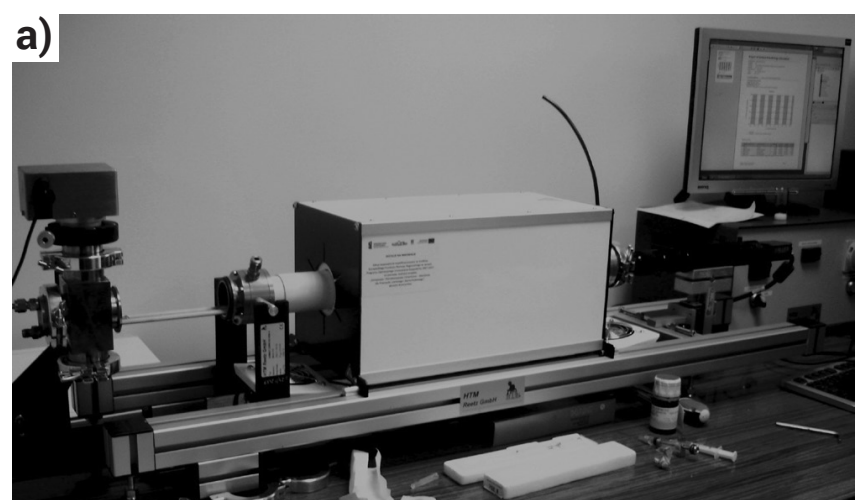

b)

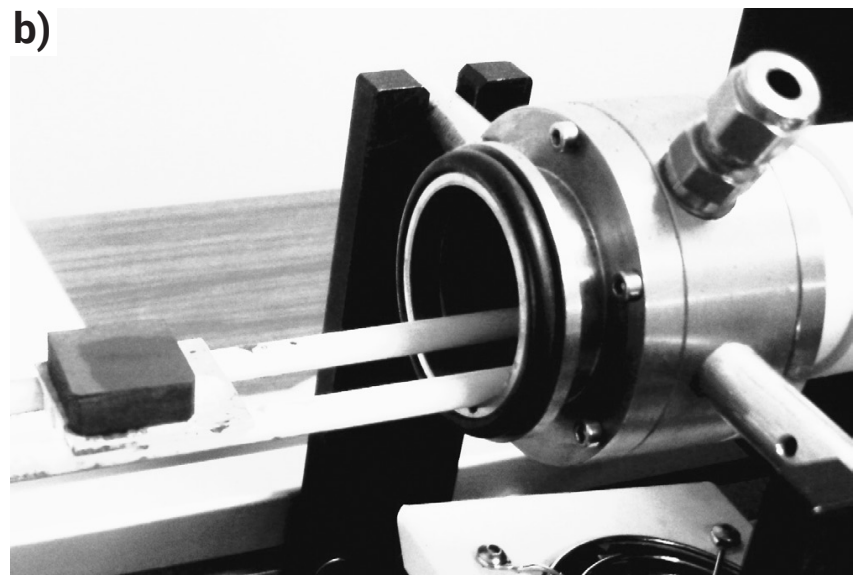

Rys. 2. Analizator energii powierzchniowej firmy KRUSS model $\operatorname{AHT12}(a, b)$

Fig. 2. Surface energy analyzer KRUSS model AHT12 (a, b)

\section{Pomiary chropowatości powierzchni}

Rodzaje obróbki powierzchni oraz otrzymane parametry chropowatości $R_{a}$ i $R_{z}$ przedstawiono w tablicy II. Zgodnie z oczekiwaniami, największą chropowatość uzyskano dla powierzchni przygotowanych poprzez obróbkę strumieniowościerną. Oddziaływanie plazmy spowodowało nieznaczne wygładzenie tych powierzchni. Podane wyniki są wartościami średnimi z trzech pomiarów.

\section{Pokrywanie próbek powłoką galwaniczną}

Do pokrywania próbek kompozytowych wybrano powłokę miedzianą. Proces pokrywania realizowano przy użyciu bezcyjankowej alkalicznej kąpieli do miedziowania SURTEC 864. Jest to kąpiel wytworzona na bazie pirofosforanów [5,12] (rys. 3).

Parametry pokrywania galwanicznego były następujące: - temperatura procesu: $60^{\circ} \mathrm{C}$,

- czas procesu: $60 \mathrm{~min}$,

- gęstość prądu: $3 \mathrm{~A} / \mathrm{dm}^{2}$.

Na rysunku 4 pokazano przekrój poprzeczny naniesionych powłok miedzianych na podłożu kompozytu grafitowego, przygotowanego przez szlifowanie i obróbkę strumieniowo-ścierną.
Tablica II. Wpływ rodzaju obróbki powierzchni na wielkość parametru chropowatości materiału kompozytowego

Table II. The influence of the surface treatment type on the roughness parameter of the composite material

\begin{tabular}{|c|c|c|}
\hline Rodzaj obróbki & $\mathbf{R}_{\mathbf{a}}[\boldsymbol{\mu m}]$ & $\mathbf{R}_{\mathbf{z}}[\boldsymbol{\mu} \mathbf{m}]$ \\
\hline Szlifowanie & 2,71 & 18,38 \\
\hline Szlifowanie+plazma & 2,62 & 17,14 \\
\hline Strumieniowo-ścierna & 9,49 & 52,09 \\
\hline Strumieniowo-ścierna+plazma & 7,56 & 45,83 \\
\hline
\end{tabular}

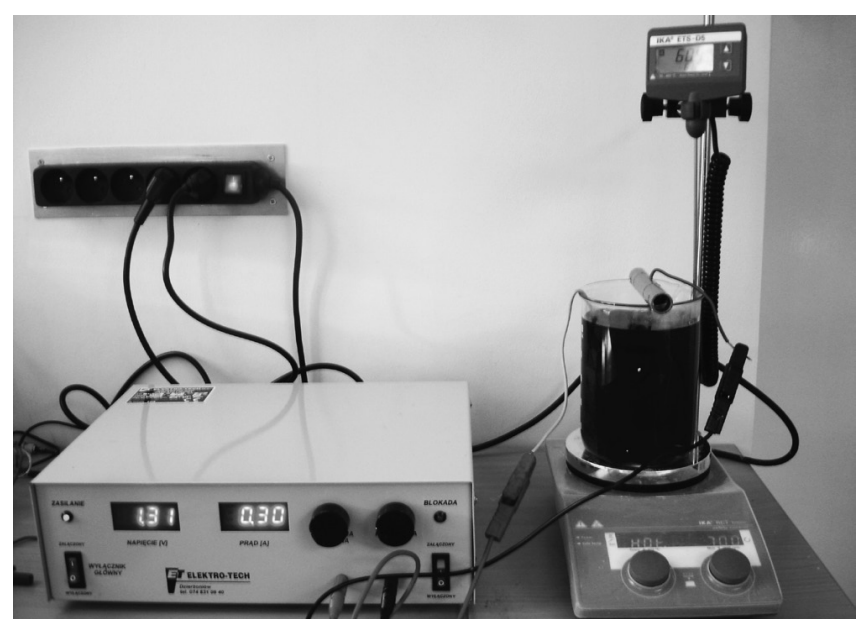

Rys. 3. Zestaw do nakładania miedzianej powłoki galwanicznej z kąpieli alkalicznej

Fig. 3. Stand for applying a copper galvanic coating from an alkaline bath
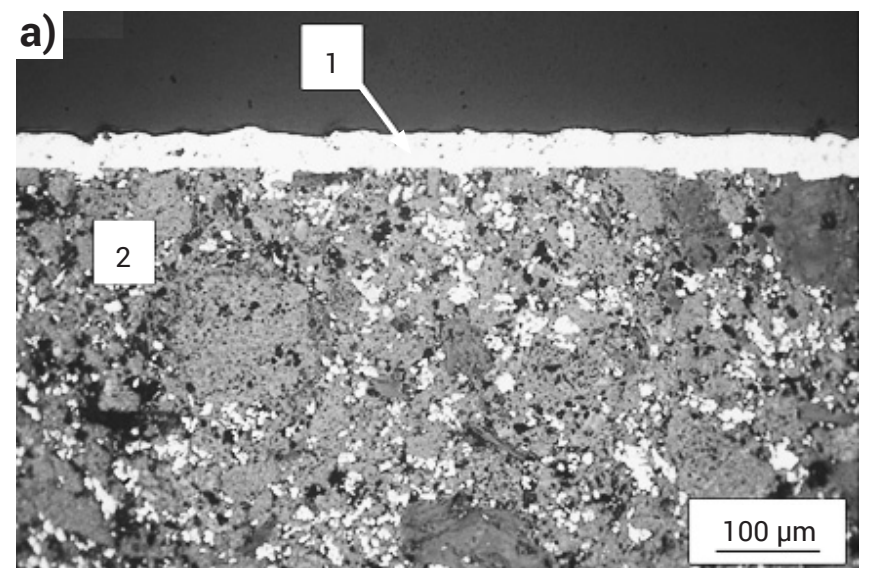

b)

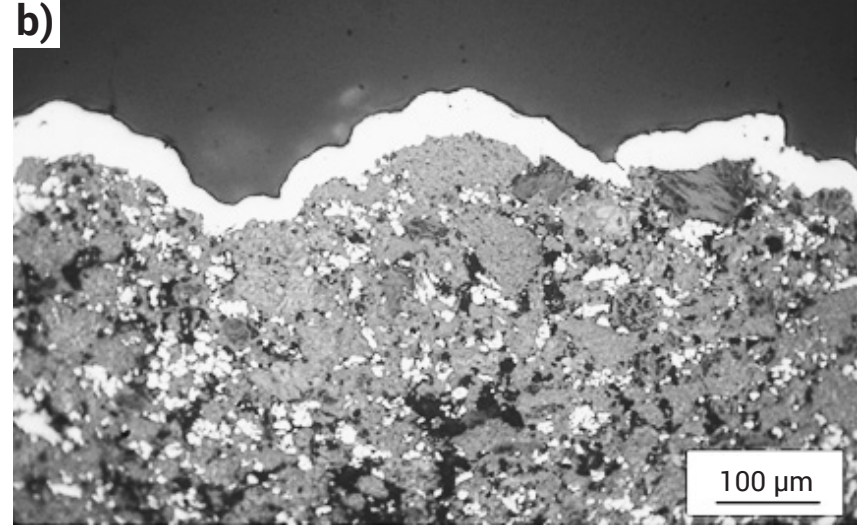

Rys. 4. Powłoki miedziane na podłożu kompozytu grafitowego, przygotowanego przez: a) szlifowanie, grubość powłoki $35 \mu \mathrm{m}$, b) obróbkę strumieniowo-ścierną, grubość powłoki $20 \div 50 \mu \mathrm{m}$; 1- powłoka $\mathrm{Cu}, 2$ - kompozyt grafitowy

Fig. 4. Copper coatings on a graphite composite substrate prepared by: a) grinding, $35 \mu \mathrm{m}$ coating thickness, b) abrasive blasting, coating thickness $20 \div 50 \mu \mathrm{m} ; 1-\mathrm{Cu}$ coating, 2 - graphite composite 


\section{Test przyczepności powłoki miedzianej do kompozytu grafitowego}

Test przyczepności nałożonych powłok miedzianych na powierzchnie przygotowanych $\mathrm{w}$ różny sposób próbek z kompozytu grafitowego przeprowadzono przy użyciu urządzenia ELCOMETER 510 z głowicą zdzierająca Ø10 mm (rys. 5).

Wstępnie zarysowano urządzeniem próbki nie pokryte, aby określić punkt odniesienia dla poszczególnych rodzajów podłoża [1].

Otrzymane wyniki zamieszczono w tablicy III, porównując je z wcześniej otrzymanymi wynikami ze statycznej próby ścinania połączeń lutowanych detali ze stopu aluminium PA38.

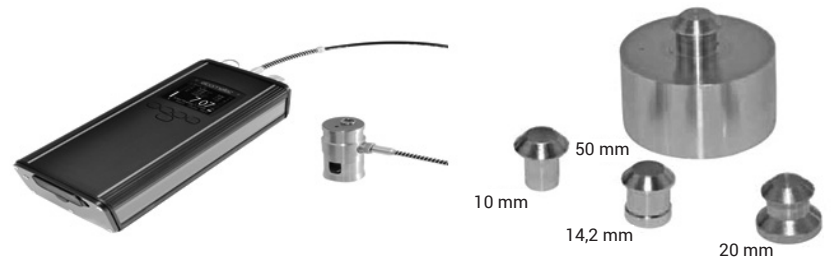

Rys. 5. Tester przyczepności powłok ELCOMETER 510 z głowicami pomiarowymi

Fig. 5. Adhesive tester ELCOMETER 510 for coatings with measuring warheads
Tablica III. Wyniki testu wytrzymałości na oderwanie powłoki galwanicznej od podłoża

Table III. Results of the test of resistance to peeling off the galvanic coating from the substrate

\begin{tabular}{|c|c|c|c|}
\hline Lp. & $\begin{array}{c}\text { Przygotowanie } \\
\text { powierzchni }\end{array}$ & $\begin{array}{c}\text { Naprężenie } \\
\text { potrzebne } \\
\text { do oderwania } \\
\text { powłoki Pz } \\
\text { [MPa] }\end{array}$ & $\begin{array}{c}\text { Wytrzymałośćc } \\
\mathbf{R}_{\mathrm{t}} \text { średnia } \\
\mathbf{z} \text { prób } \\
\text { statycznego } \\
\text { ścinania [MPa] }\end{array}$ \\
\hline 1. & szlifowanie & 7,0 & 6,3 \\
\hline 2. & szlifowanie+plazma & 9,6 & 9,4 \\
\hline 3. & $\begin{array}{c}\text { obróbka strumieniowo- } \\
\text {-ścierna }\end{array}$ & 14,8 & 12,5 \\
\hline 4. & $\begin{array}{c}\text { obróbka strumieniowo- } \\
\text {-ścierna+plazma }\end{array}$ & 22,8 & 17,6 \\
\hline
\end{tabular}

Charakter połączenia nałożonych powłok galwanicznych miedzianych na podłoże z kompozytu grafitowego obrabianego przez obróbkę szlifierską był przeważnie adhezyjny. Natomiast w przypadku próbek po obróbce strumieniowościernej i obróbką z użyciem zimnej plazmy, charakter połączenia był mieszany, tj. częściowo adhezyjny, a częściowo kohezyjny.

\section{Wnioski}

Na podstawie przeprowadzonych badań sformułowano następujące wnioski:

1. Wytwarzanie dobrej jakości połączeń kompozytu grafitowego ze stopem aluminium PA38 metodą lutowania miękkiego

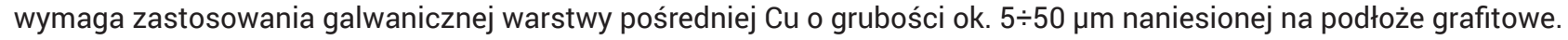

2. Decydujący wpływ na przyczepność naniesionych powłok miedzianych na podłoże z kompozytu grafitowego ma sposób przygotowania powierzchni materiału podłoża. Zastosowanie obróbki strumieniowo-ściernej powierzchni połączonej z obróbką zimną plazmą z zastosowaniem argonu, umożliwia prawie dwukrotny wzrost wytrzymałości na oderwanie powłoki od podłoża.

3. Zastosowanie dodatkowo obróbki zimną plazmą powierzchni pod pokrycie galwaniczne zwiększa w sposób znaczący przyczepność powłoki do podłoża.

\section{Literatura}

[1] Adams R.D.: Adhesive bonding Science, technology and application, Woodhead Publishing Limited 2005.

[2] Biestek T., Sękowski S.: Metody badań powłok metalowych, WNT, Warszawa 1973

[3] Borcia G., Chiper A., Rusu I.: Using a $\mathrm{He}+\mathrm{N}_{2}$ dielectric barrier discharge for the modification of polymer surface properties, Plasma sources Sci. Technol., 2006, 15, pp. 849-857.

[4] Stryczewska H.D.: Technologie zimnej plazmy, Wytwarzanie, modelowanie, zastosowania, Elektryka, 201, zeszyt 1 (217), rok LVII, Instytut Podstaw Elektrotechniki i Elektrotechnologii, Politechnika Lubelska, Lublin 2014.

[5] Campbell F., Frauenhofer J.A.: Surface Technology, 1976, 4, pp. 403-406.

[6] Chmielewski T.: Wykorzystanie energii kinetycznej tarcia i fali detonacyjnej do metalizacji ceramiki, Prace naukowe PW, Seria Mechanika, Zeszyt 232, Warszawa 2012

[7] Critchlow G.W., Brewis D. M.: Review of surface pretreatments for aluminium alloys, Int. J. Adhes. Adhes.,1996, 16, pp. 255-275.
[8] Iorio I. De, Leone C., Nele L., Tagliaferri V.: Plasma treatments of polymeric materials and Al alloy for adhesive bonding, J. Mater. Process Technol., 1997, 68, pp. 179-183.

[9] Mirski Z., Wojdat T., Stachowicz M.: Soldering of aluminium with copper and steel using intermediate layer $\mathrm{Zn}-\mathrm{Ni}$, Archives of Civil and Mechanical Engineering, 2015, vol. 15, nr 4, pp. 903-910.

[10] Mirski Z.,Wojdat T., Piwowarczyk T., Granat K., Derlukiewicz W., Ciepacz I., Jakubczyk A.: Lutowanie miękkie kompozytu grafitowego ze stopem aluminiowym PA38, Przegląd Spawalnictwa, 2016, vol. 88, nr 9, s. 50-55.

[11] Tioshifuji J., Katsumata T., Takikawa H., Sakakibara T. \& Shimizu I.: Cold arc- plasm jet on the atmospheric pressure for surface modification, Surface and Coating Tech. 2003, 171, pp. 302-306.

[12] Wiedemann R., Motta de Sillos R.: Technical Handbook, Surface Treatments, 2007, pp. 136-138. 


\title{
Analiza wpływu przygotowania powierzchni zimną plazmą na lutowność stopów aluminium i magnezu
}

\author{
The influence of cold plasma-surface modification \\ on the solderability of aluminum and magnesium alloys
}

\section{Streszczenie}

W niniejszym artykule dokonano oceny zastosowania technologii zimnej plazmy atmosferycznej, jako metody przygotowania powierzchni metali trudno spajalnych do procesu lutowania. Omówiono materiały dodatkowe stosowane do lutowania twardego stopów magnezu i aluminium oraz wskazano na problemy występujące podczas ich lutowania. Przedstawiono wyniki badań lutowności poprzez próby zwilżalności i rozpływności, stopu aluminium PA11 przy użyciu spoiwa Al 112 (B-Al88Si12) i topnika Al 700 oraz stopu magnezu AZ31B przy użyciu spoiwa Mg 001 (B-MgAl9Zn3Mn1) i topnika FMAG opracowanego w Instytucie Spawalnictwa w Gliwicach. Przeprowadzono analizę porównawczą prób zwilżalności i rozpływności przed i po obróbce zimną plazmą. Wykazano znaczący wpływ obróbki zimną plazmą atmosferyczną na poprawę lutowności stopów aluminium PA1 1 i magnezu AZ31B.

Słowa kluczowe: zimna plazma; lutowanie magnezu; lutowanie aluminium; lutowność

\begin{abstract}
In this article the possibility of application of cold plasma technology for surface treatment of difficult-to-braze metals (PA11 aluminum alloys and AZ31B magnesium alloys) was evaluated. The filler metals used for brazing of magnesium and aluminum alloys, as well as the issues encountered during the process were discussed. The research were carried out: wettability and spreadability tests of PA11 aluminum alloy using Al 112 (B-Al88Si12) braze and Al 700 flux; and flame brazing of AZ31B magnesium alloy using Mg 001 (B-MgAI9Zn3Mn1) braze and FMGA flux developed at the Welding Institute in Gliwice. The wetting and spreadability were investigated with and without the use of cold plasma treatment and a comparative analysis was presented. Finally, the significant effect of the cold plasma plasma-surface modification on the brazebility of PA11 aluminum alloys and AZ31B magnesium alloys was demonstrated.
\end{abstract}

Keywords: cold plasma; magnesium brazing; aliminum brazing; brazebility

\section{Wstęp}

Od drugiej połowy $\mathrm{XX}$ wieku zainteresowanie stopami aluminium i magnezu systematycznie rośnie. Ze względu na swoje właściwości znajdują zastosowanie m.in. w przemyśle motoryzacyjnym, budowlanym, elektronicznym, lotniczym i kosmicznym $[5,7,9,11]$. Stopy te dzięki małej gęstości (dla magnezu ok. 1,7 kg/dm ; dla aluminium ok. 2,8 kg/dm ${ }^{3}$ ), dobrej wytrzymałości i odporności na korozję są bardzo korzystnymi materiałami konstrukcyjnymi. W przypadku magnezu oprócz bardzo małej gęstości niewątpliwy atut stanowi wysoka zdolność do tłumienia drgań $[3,4,7,8]$.

Zarówno stopy magnezu, jak i aluminium należą do grupy materiałów trudno spajalnych. Szczególne trudności przysparza ich lutowanie. Wpływ na to ma ich stosunkowo niska temperatura topnienia. W przypadku aluminium szczególnie niekorzystna jest wysoka temperatura topnienia tlenków $\mathrm{Al}_{2} \mathrm{O}_{3}$ $\left(2060{ }^{\circ} \mathrm{C}\right)$, duża przewodność cieplna, duży współczynnik rozszerzalności liniowej oraz fakt, że po nagrzaniu do temperatury lutowania twardego aluminium i jego stopy wykazują spadek właściwości wytrzymałościowych [12].

W stopach magnezowych ze względu na niskie wartości temperatury solidus mogą wystąpić odkształcenia podczas lutowania, złącza mogą wykazywać niską odporność na korozję atmosferyczną, a łatwa erozja metalu łączonego przez spoiwo znacząco wpływa na obniżenie właściwości mechanicznych połączeń [4].

Główną komplikacją przy lutowaniu stopów Mg i Al, decydującą o poprawnym wykonaniu złącza, jest obecność powierzchniowej warstwy tlenków, ograniczającej jej zwilżanie spoiwami lutowniczymi [7]. Z powodu natychmiastowego ponownego utleniania się materiałów, zarówno mechaniczne, jak i chemiczne oczyszczanie powierzchni nie daje wymaganych rezultatów. W niniejszych badaniach podjęto próbę

Dr inż. Tomasz Wojdat; dr hab. inż. Zbigniew Zimniak, prof. PWr; Izabela Łącka - Politechnika Wrocławska.

Autor korespondencyjny/Corresponding author: zbigniew.zimniak@pwr.edu.pl 
poprawy lutowności stopów Al i Mg poprzez zmniejszenie napięcia powierzchniowego, stosując obróbkę zimną plazmą atmosferyczną. Efekt ten jest możliwy do osiągnięcia w wyniku zmniejszenia ilości zanieczyszczeń organicznych, w tym tlenkowych - nawet 4-krotne zmniejszenie ilości tlenu na powierzchni [6].

Zimna plazma atmosferyczna, nazywana czwartym stanem skupienia materii ze względu na swoją inność od stanu ciekłego, gazowego czy stałego, w przygotowaniu powierzchni jest głównie znana z zastosowania jej do tworzyw sztucznych [1,2]. Wykorzystywana jest m.in. w technologii chemicznej w celu: wytrawiania i modyfikacji powierzchni, osadzania cienkich warstw, oczyszczania ścieków, czy też w inżynierii biomedycznej do sterylizacji narzędzi [1].

\section{Materiały użyte do badań}

W badaniach zastosowano materiały podstawowe, które w warunkach przemysłowych często przysparzają problemów podczas ich spajania. Wybrano po jednym stopie aluminium i magnezu, o oznaczeniach odpowiednio PA1 1 i AZ31B. Materiały te należą do grupy materiałów trudno spajalnych, a z uwagi na coraz częstsze wykorzystanie ich w przemyśle motoryzacyjnym, lotniczym i kosmicznym, często istnieje potrzeba wytwarzania połączeń, w tym lutowanych, które pod względem właściwości eksploatacyjnych muszą spełniać często bardzo wysokie wymagania. Skład chemiczny i podstawowe właściwości stopów wybranych

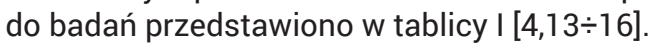

Do prób lutowania stopu aluminium PA11 wybrano okołoeutektyczny stop Al-Si o oznaczeniu Al 112 (B-Al88Si12) zawierający ok. $12 \%$ wag. Si oraz topnik oparty na bazie chlorków sodu i potasu o oznaczeniu Al 700. Temperatura aktywności topnika zawiera się w zakresie $500 \div 650{ }^{\circ} \mathrm{C}$. Natomiast do lutowania stopu magnezu AZ31B użyto lutu magnezowego o oznaczeniu Mg 001 (B-MgAl9Zn3Mn1) w połączeniu z topnikiem FMAG, opracowanym w Instytucie Spawalnictwa w Gliwicach, opartym na bazie chlorków potasu, litu i wapnia oraz fluorku sodu. Temperatura aktywności topnika FMAG mieści się w zakresie $400 \div 600{ }^{\circ} \mathrm{C}$ [4]. Skład chemiczny wraz z temperaturą topnienia wybranych lutów twardych przedstawiono w tablicy II.

\section{Próby rozpływności i zwilżalności}

Wykonanie połączeń lutowanych o dobrej jakości determinowane jest uzyskaniem dobrej zwilżalności powierzchni spoiwem lutowniczym. Aby lut mógł zwilżać i swobodnie rozpływać się po powierzchni spajanych materiałów należy zmniejszyć napięcie powierzchniowe. W przypadku stopów aluminium zawierających powyżej $2 \%$ wag. Mg i stopów magnezu, pomimo stosowania topników o dużej aktywności chemicznej, uzyskanie dobrej zwilżalności i rozpływności jest znacznie utrudnione z uwagi na dużą trwałość chemiczną warstwy tlenkowej, co może powodować problemy z uzyskaniem złączy o wysokiej jakości. W badaniach podjęto próbę polepszenia zwilżalności i rozpływności wybranych stopów Al i Mg poprzez zastosowanie technologii zimnej plazmy atmosferycznej bezpośrednio przed procesem lutowania.

Ponieważ obydwa parametry (zwilżalność i rozpływność) są ze sobą ściśle powiązane, to oceny skuteczności przygotowywania powierzchni do procesów lutowania metodą zimnej plazmy dokonano metodą rozpływności wybranych lutów na badanych podłożach. Z blach ze stopów Al i Mg o grubości 2,0 mm wycięto próbki o wymiarach 40 x 40 mm, których powierzchnię do badań przygotowano na dwa sposoby. odtłuszczenie rozpuszczalnikiem Nitro oraz poprzez obróbkę zimną plazmą wytworzoną z argonu, przy użyciu urządzenia o mocy $300 \mathrm{~W}$ i napięciu 18 kV (rys. 1). Czas oddziaływania strumienia zimnej plazmy na każdą próbkę wynosił $60 \mathrm{~s}$.

$\mathrm{Na}$ tak przygotowanych podłożach układano porcję lutu o masie 0,1 g wraz z topnikiem w takiej samej ilości i nagrzewano od góry płomieniem propanowo-powietrznym. Czas nagrzewania próbek od momentu stopienia się lutu wynosił $5 \mathrm{~s}$. Przygotowano po 5 próbek dla każdej z metod przygotowania powierzchni i dla każdego rodzaju lutu. W celu określenia rozpływności zmierzono pola powierzchni rozpłyniętych kropli lutu przy użyciu programu DP-Soft Olympus

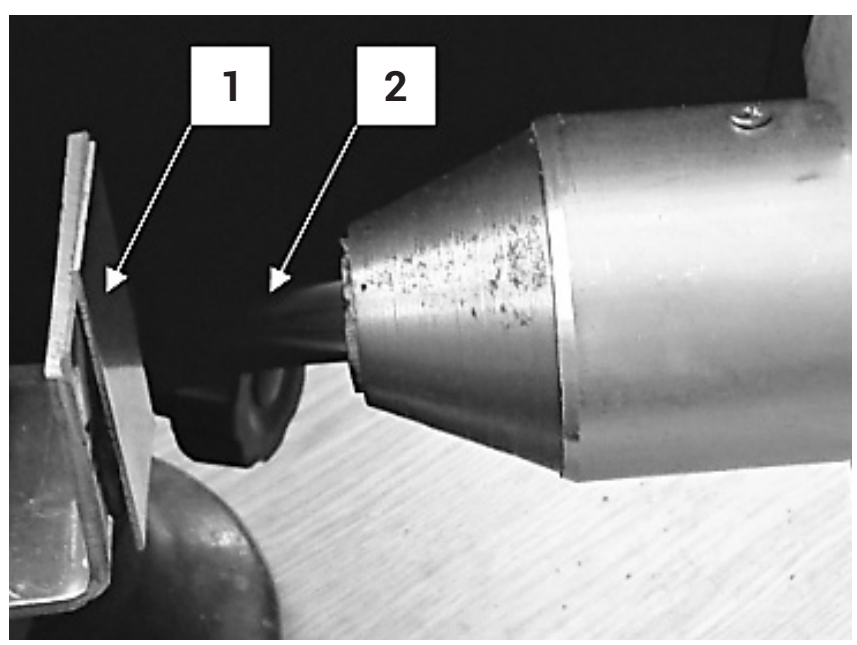

Rys. 1. Oczyszczanie powierzchni przy użyciu zimnej plazmy wytworzonej z argonu: 1 - próbka, 2 - strumień zimnej plazmy

Fig. 1. Surface cleaning using cold plasma generated from argon: 1 - sample, 2 - stream of cold plasma

Tablica I. Skład chemiczny i podstawowe właściwości stopu aluminium PA1 1 i magnezu AZ31B $[4,13 \div 16]$

Table I. Chemical composition and basic properties of aluminum alloy PA1 1 and magnesium AZ31B $[4,13 \div 16]$

\begin{tabular}{|c|c|c|c|c|c|c|c|c|}
\hline \multirow{2}{*}{ Oznaczenie } & \multicolumn{4}{|c|}{ Skład chemiczny [\% wag.] } & \multirow{2}{*}{$\begin{array}{l}\text { Temperatura } \\
\text { topnienia }\left[{ }^{\circ} \mathrm{C}\right]\end{array}$} & \multirow{2}{*}{$\begin{array}{l}\text { Gęstość } \\
{\left[\mathrm{kg} / \mathrm{dm}^{3}\right]}\end{array}$} & \multirow{2}{*}{$\begin{array}{c}\text { Wytrzymałość na } \\
\text { rozciąganie } R_{m}[\mathrm{MPa}]\end{array}$} & \multirow{2}{*}{$\begin{array}{c}\text { Wydłużenie } \\
\text { względne } A_{5}[\%]\end{array}$} \\
\hline & Al & Mg & $\mathrm{Zn}$ & inne & & & & \\
\hline PA11 & reszta & $2,6 \div 3,6$ & 0,2 & $0,5 \mathrm{Mn} ; 0,4 \mathrm{Si} ; 0,3 \mathrm{Cr}$ & $595 \div 645$ & 2,67 & $190 \div 200$ & $10 \div 14$ \\
\hline AZ31B & 3,0 & reszta & 1,0 & $0,2 \mathrm{Mn}$ & $605 \div 630$ & 1,77 & 193 & 14 \\
\hline
\end{tabular}

Tablica II. Skład chemiczny i temperatura topnienia lutów twardych Al 112 i Mg $001[4,13]$

Table II. Chemical composition and melting point of hard solders Al 112 i Mg $001[4,13]$

\begin{tabular}{|c|c|c|c|c|c|c|c|}
\hline \multirow{2}{*}{ Oznaczenie } & \multicolumn{5}{|c|}{ Skład chemiczny [\% wag.] } & \multirow{2}{*}{$\begin{array}{l}\text { Temperatura } \\
\text { topnienia }\left[{ }^{\circ} \mathrm{C}\right]\end{array}$} & \multirow{2}{*}{$\begin{array}{l}\text { Temperatura } \\
\text { lutowania }\left[{ }^{\circ} \mathrm{C}\right]\end{array}$} \\
\hline & Al & $\mathrm{Mg}$ & $\mathrm{Si}$ & $\mathrm{Zn}$ & inne & & \\
\hline Al 112 & reszta & - & 12,0 & - & - & $575 \div 585$ & $590 \div 610$ \\
\hline Mg 001 & $8,3 \div 9,7$ & reszta & - & $1,7 \div 2,3$ & $0,15 \div 0,5 \mathrm{Mn}$ & $443 \div 599$ & $582 \div 616$ \\
\hline
\end{tabular}


Tablica III. Wyniki prób rozpływności i zwilżalności na podłożach ze stopu aluminium PA1 1 i magnezu AZ31B

Table III. Results of spread and wettability tests on aluminum alloy substrates PA11 and magnesium AZ31B

\begin{tabular}{|c|c|c|}
\hline Materiał & Rozpływność $\mathrm{Pp}_{\text {sr }}\left[\mathbf{m m}^{2}\right]$ & Zwilżalność $\boldsymbol{\theta}\left[^{\circ}\right]$ \\
\hline PA11 & 184 & 12 \\
\hline PA11 + plazma & 285 & 5 \\
\hline AZ31B & 142 & 11 \\
\hline AZ31B + plazma & 405 & 4 \\
\hline
\end{tabular}

z funkcją planimetrowania powierzchni. Dla określenia zwilżalności, próbki przecięto w połowie rozpłyniętej kropli lutu, zainkludowano w żywicy epoksydowej i przygotowano zgłady metalograficzne. Następnie w sposób graficzny wyznaczono kąty zwilżania poszczególnych próbek. Wyniki pomiarów rozpływności i zwilżalności zestawiono w tablicy III. Są to wartości średnie z pięciu pomiarów.

Na rysunku 2 pokazano przykładowe pola rozpływności i kąty zwilżania lutów twardych na podłożach ze stopu aluminium PA1 1 i magnezu AZ31B.

Zastosowanie technologii zimnej plazmy, jako metody obróbki powierzchni stopu aluminium PA11 i magnezu AZ31B do procesu lutowania, spowodowało znacznie polepszenie rozpływności, o czym świadczą dużo większe pola powierzchni rozpłyniętych kropli spoiwa na obydwu podłożach oraz mniejsze wartości kąta zwilżania. Spowodowane jest to zmniejszeniem napięcia powierzchniowego oraz wyniku oczyszczenia (zmniejszeniem ilości zanieczyszczeń organicznych) powierzchni poddanych jej działaniu, przez co tworzący się w trakcie prób lutowania żużel topnikowy jest znacznie mniej nasycony tlenkami i mniej przyczepny do podłoża, umożliwiając swobodne zwilżanie i rozpływanie się lutu po materiale lutowanym. Przeprowadzone próby technologiczne potwierdzają dużą skuteczność technologii zimnej plazmy, jako metody przygotowania podłoży materiałów trudno spajalnych do procesu lutowania.

\section{Badania metalograficzne złączy lutowanych}

Skuteczność metody zimnej plazmy oceniono również na podstawie badań metalograficznych złączy lutowanych. Przygotowano zakładkowe złącza lutowane dla każdej z par metali z zastosowaniem oczyszczania powierzchni metodą zimnej plazmy wytworzonejz argonu ibez (powierzchnia tylko odtłuszczona). Długość zakładki wynosiła ok. $10 \mathrm{~mm}$, a szerokość szczeliny lutowniczej ustalono za pomocą stalowych drucików dystansowych na 0,2 mm. Podobnie jak w przypadku prób rozpływności złącza wykonano przez nagrzewanie płomieniowe przy użyciu palnika na propan-powietrze dozując ręcznie lut na krawędzi zakładki.

Podczas lutowania stopu aluminium PA11, niezależnie od sposobu przygotowania powierzchni łączonych materiałów, nie występowały problemy utrudniające wykonanie połączenia, a lut swobodnie wnikał do kapilarnej szczeliny. Badania metalograficzne złączy lutowanych wykazały jednak znaczące różnice w jakości złączy. W złączach, których elementy do lutowania przygotowano przez obróbkę zimną plazmą, występują śladowe ilości niezgodności lutowniczych w postaci niedużych wtrąceń żużla topnikowego (rys. 3a). Są to typowe niezgodności charakterystyczne dla procesu lutowania topnikowego, które nie stanowią zagrożenia dla prawidłowej funkcjonalności złącza. W przypadku złączy niepoddanych obróbce zimną plazmą występują nieciągłości lutownicze (miejsca niewypełnione lutem) spowodowane pozostałościami żużla topnikowego, niewypartego przez ciekły lut (rys. 3b). Spowodowane jest to dużym nasyceniem tlenkowym żużla, zwiększającym jego gęstość i przyczepność do podłoża, przez co jego wypieranie ze szczeliny przez spoiwo jest znacznie utrudnione.

Dużo bardziej utrudnione było wykonanie złączy ze stopu magnezu AZ31B. Problemy spowodowane były głównie przez małą różnicę pomiędzy temperaturą topnienia stopu AZ31B $\left(605 \div 630^{\circ} \mathrm{C}\right)$ i spoiwa Mg 001, którego górna granica likwidus wynosi $599^{\circ} \mathrm{C}$ (zalecana temperatura lutowania $582 \div 616^{\circ} \mathrm{C}$ ) [4]. Tak nieduża różnica temperatury topnienia spoiwa i materiału rodzimego jest szczególnie niekorzystna
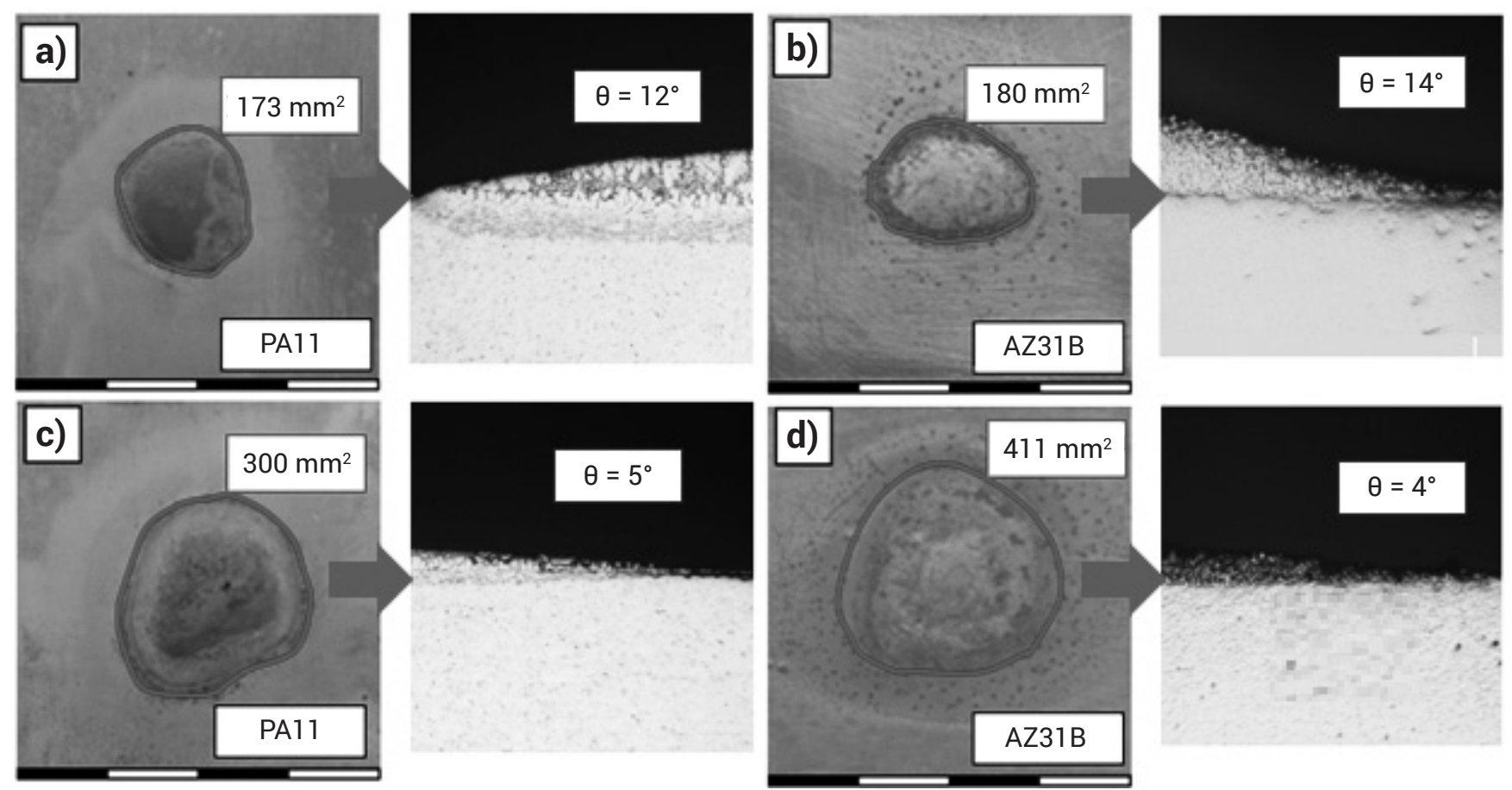

Rys. 2. Rozpływność i zwilżalność lutów twardych na podłożach ze stopu aluminium PA11 i magnezu: a, b) powierzchnia odtłuszczona, c, d) powierzchnia poddana działaniu zimnej plazmy

Fig. 2. Wettability and wetting of hard solders on aluminum alloy PA11 and magnesium substrates: a, b) degreased surface, c, d) surface treated with cold plasma 

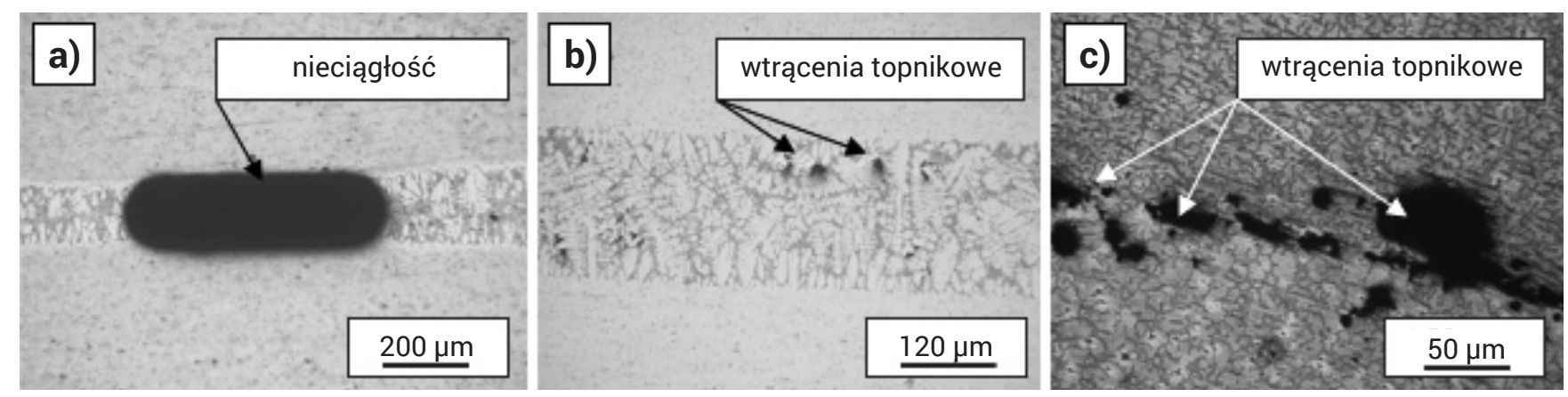

Rys. 3. Mikrostruktura złączy lutowanych: a) stop aluminium PA11 bez obróbki zimną plazmą, b) stop aluminium PA11 po obróbce zimną plazmą, c) stop magnezu AZ31B po obróbce zimną plazmą

Fig. 3. Microstructure of solder joints: a) PA11 aluminum alloy without cold plasma treatment, b) PA11 aluminum alloy after cold plasma treatment, c) AZ31B magnesium alloy after cold plasma treatment

w przypadku lutowania elementów o grubości poniżej 3,0 mm, a która w rozpatrywanym przypadku wynosiła $2,0 \mathrm{~mm}$. Powodowało to, że w konsekwencji wykonanie złącza bez odpowiedniego przygotowania powierzchni łączonych elementów było niemożliwe. Podczas lutowania tworzył się silnie nasycony tlenkami żużel topnikowy ograniczający kapilarne wnikanie spoiwa magnezowego o małej gęstości (mniejszej od gęstości żużla) do szczeliny lutowniczej. Próba wykonania złącza wymagała zatem wydłużenia czasu lutowania, co skutkowało przegrzaniem materiału rodzimego, powodując jego nadtapianie się od krawędzi uniemożliwiając tym samym utrzymanie kapilarnej szerokości szczeliny lutowniczej. Oczyszczenie powierzchni metodą zimnej plazmy umożliwiło wykonanie złącza lutowanego, ale należy podkreślić, że mimo wszystko lutowanie cienkich blach ze stopów Mg było utrudnione i wymagało dużej precyzji. Tworzący się żużel o mniejszym nasyceniu tlenkowym był bardziej rzadkopłynny i nie ograniczał swobodnego wnikania lutu do szczeliny lutowniczej, przez co uniknięto przegrzania i nadtopienia materiału rodzimego. Nie pozwoliło to jednak na całkowite wyeliminowanie niezgodności lutowniczych w postaci wtrąceń topnikowych (rys. 3c). Pomimo niedużego nasycenia żużla tlenkami i dużej rzadkopłynności, jego całkowite wyparcie przez lut ze szczeliny lutowniczej jest ograniczone małą gęstością spoiwa magnezowego.

\section{Wnioski}

Na podstawie analizy wyników otrzymanych z przeprowadzonych badań sformułować można następujące wnioski:

- technologia zimnej plazmy jest wysoce skuteczną metodą przygotowania powierzchni metali trudno spajalnych do procesów lutowania, o czym świadczą większe pola rozpływności i mniejsze wartości kątów zwilżania (różnica ok. 70\%);

- żużel topnikowy tworzący się na powierzchni metali poddanych działaniu zimnej plazmy jest mniej nasycony tlenkami i bardziej rzadkopłynny, przez co nie jest z nią silnie związany, ułatwiając tym samym swobodne rozpływanie się lutu i lepsze zwilżanie;

- oczyszczenie powierzchni stopów aluminium i magnezu metodą zimnej plazmy umożliwia uzyskanie połączeń o wysokiej jakości, charakteryzujących się brakiem lub śladową ilością niezgodności lutowniczych typowych dla procesu lutowania z użyciem topnika;

- rzadkopłynny żużel o małym nasyceniu tlenkami, będący wynikiem użycia zimnej plazmy, jest skutecznie wypierany ze szczeliny lutowniczej przez ciekły lut, nawet o małej gęstości (luty magnezowe i aluminiowe), zmniejszając ryzyko występowania niezgodności w lutowinie.

\section{Literatura}

[1] Stryczewska H. D.: Technologie zimnej plazmy. Wytwarzanie, modelowanie, zastosowania, Elektryka, Zeszyt 1, 2011, s. 41-61.

[2] Bernaciak M.: Technologia aktywacji, czyszczenia i powlekania powierzchni tworzyw sztucznych, AMB Technic.

[3] Dziado A., Mola R.: Magnez - kierunki kształtowania własności mechanicznych, Obróbka Plastyczna Metali vol. XXIV, nr 4/2013, s. 253-277.

[4] Winiowski A., Majewski D.: Lutowanie twarde stopów magnezu, Przegląd Spawalnictwa vol. 86, nr 12/2014, s. 41-48.

[5] Alou A.: Magnesium: Current and Potential Automotive Applications, JOM, February 2002.

[6] Sorrentino L., Carrino L.: 2024 aluminium alloy wettability and superficial cleaning improvement by air cold plasma treatment, Journal of Materials Processing Technology, 2009, pp. 1400-1409.

[7] Piątkowski J., Binczyk F.: Właściwości i zastosowanie odlewniczych stopów Mg-Al, Archiwum Odlewnictwa, nr 4/2002.

[8] Dobrzański L.A.: Stopy metali lekkich, IMliB, Gliwice 2007.
[9] Janik B.: Zastosowanie stopów magnezu w lotnictwie, Prace Instytutu Lotnictwa, Warszawa 2011, s. 102-108.

[10] Szałatkiewicz J.: Zastosowanie plazmy w technice - aktualne tendencje, Pomiary Automatyka Robotyka 2/2010, s. 17-20.

[11] Kuczmaszewski J., Zaleski K.: Obróbka skrawaniem stopów aluminium i magnezu, Lublin 2015.

[12] Pilarczyk J. (red.): Poradnik inżyniera. Spawalnictwo, Tom 2, WNT, Warszawa 2005.

[13] PN-EN ISO 17672:2016-12 Lutowanie twarde - spoiwa.

[14] PN-EN 1754:2015-10 Magnez i stopy magnezu - System oznaczenia anod, gąsek i odlewów - Symbole materiału i numery materiału.

[15] PN-EN 485-2:2016-10 Aluminium i stopy aluminium - Blachy, taśmy i płyty - Część 2: Własności mechaniczne.

[16] PN EN 573-3:2014-02 Aluminium i stopy aluminium - Skład chemiczny i rodzaje wyrobów przerobionych plastycznie - Część 3: Skład chemiczny i rodzaje wyrobów. 


\title{
Analiza fazowa strefy granicznej połączenia stopu Hastelloy X z lutem Palnicro 36M
}

\author{
Phase analysis of phase boundary zone \\ for Hastelloy X with Palnicro 36M brazed joint
}

\section{Streszczenie}

W artykule scharakteryzowano strefę graniczną połączenia Hastelloy X - Palnicro $36 \mathrm{M}$, w której oddziaływały bezpośrednio ciekły lut z materiałem podłoża w stanie stałym. Głównym celem prowadzonych badań była analiza mikrostruktury strefy granicznej oraz identyfikacja występujących w niej faz. W badaniach wykorzystano mikroskopie świetlną, skaningową mikroskopie elektronową (SEM) wraz z analizą EDS oraz metodę dyfrakcji rentgenowskiej (XRD).

W strefie granicznej zidentyfikowano fazy tworzone przez: molibden nikiel $\left(\mathrm{Mo}_{1,08} \mathrm{Ni}_{2,92}\right)$, tetrataenite NiFe, chrom nikiel (CrNi), bor chrom $\mathrm{Cr}_{5} \mathrm{~B}_{3}$. Badania wskazały również na możliwość występowania w strefie granicznej faz na bazie związków międzymetalicznych $\mathrm{Cr}_{3} \mathrm{NiB}_{6} \mathrm{i} \mathrm{Mo}_{6}\left(\mathrm{Ni}_{0,75} \mathrm{Si}_{0,25}\right)_{7}$.

Słowa kluczowe: lutowanie twarde; lut Palnicro 36M; dyfrakcja rentgenowska

\begin{abstract}
The article describes boundary zone for the Hastelloy $X$ - Palnicro 36M brazed joint, in which liquid brazing filler metal interacted directly with solid base metal. The main objective of the research was to analyze the microstructure of the border zone and to recognize the occurring phases. Methods used in the research were light microscopy, scanning electron microscopy (SEM) with EDS analysis and X-ray diffraction (XRD).

In the phase boundary zone the following phases were identified: molybdenum nickel $\left(\mathrm{Mo}_{1.08} \mathrm{Ni}_{2.92}\right)$, tetrataenite $\mathrm{NiFe}$, chromium nickel ( $\mathrm{CrNi}$ ), boron chromium $\mathrm{Cr}_{5} \mathrm{~B}_{3}$. Studies have also indicated the possibility of occurrence of phases based on $\mathrm{Cr}_{3} \mathrm{NiB}_{6}$ and $\mathrm{Mo}_{6}\left(\mathrm{Ni}_{0.75} \mathrm{Si}_{0.25}\right)_{7}$ intermetallic compound in the phase boundary zone.
\end{abstract}

Keywords: brazing; brazing alloy Palnicro 36M; X-ray diffraction

\section{Wprowadzenie}

We współczesnych silnikach lotniczych istotną rolę odgrywają żaroodporne i żarowytrzymałe stopy na bazie niklu, tzw. superstopy. Jedną z metod spajania superstopów stosowanych w przemyśle lotniczym jest lutowanie twarde

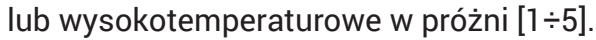

Do lutowania superstopów niklowych w przemyśle lotniczym często stosowane są luty na bazie niklu z serii BNi. Jednym z głównych przedstawicieli tej grupy stopów jest lut BNi-2, który oprócz Ni posiada dodatki Cr, Fe, B i Si. W silnikach lotniczych znajdują się również złącza wykonane przy użyciu Palnicro 36M, który jest lutem spoza serii BNi. W tym stopie głównym składnikiem jest Ni wraz z dodatkami Cr, B, Si i Pd. W stosunku do BNi-2 różni się on brakiem Fe oraz obecnością Pd - ok. 36\%. Skład chemiczny, a także temperaturę solidus, likwidus oraz zalecaną temperaturę luto-

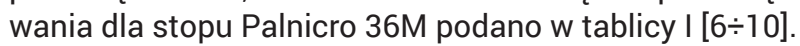

W połączeniu lutowanym na przykładzie pary materiałów Hastelloy X - Palnicro 36M można wyróżnić 3 podstawowe strefy: strefa wielofazowa, faza podstawowa i strefa graniczna, w której bezpośrednio oddziaływały ciekły lut i materiał podłoża. Strukturę połączenia z widocznymi 3 strefami przedstawiono na rysunku 1 (mikroskopia świetlna).

Dostępne są prace $[11 \div 14]$, w których analizie poddano strukturę złączy lutu Ni-Cr-Pd ze stalami nierdzewnymi i superstopami niklu z grupy Inconel. W niniejszej pracy skupiono się na bardzo wąskiej strefie, gdzie bezpośrednio oddziaływały ciekły lut z podłożem w stanie stałym (strefa graniczna). Przeprowadzone badania miały na celu określenie składu fazowego granicznej strefy lut - podłoże.

Tablica I. Skład chemiczny lutu Palnicro 36M, \% wag. [9] Table I. Chemical composition of Palnicro 36M, wt.\% [9]

\begin{tabular}{|c|c|c|c|c|}
\hline Pd & Ni & Cr & Si & B \\
\hline 35,6 & Bal. & 10,5 & 0,5 & 3,0 \\
\hline \multicolumn{3}{|c|}{ Temperatura Solidus } & \multicolumn{2}{|c|}{$820^{\circ} \mathrm{C}$} \\
\hline \multicolumn{2}{|c|}{ Temperatura Likwidus } & \multicolumn{2}{|c|}{$960^{\circ} \mathrm{C}$} \\
\hline \multicolumn{2}{|c|}{ Zalecana temperatura lutowania } & $970 \div 1050{ }^{\circ} \mathrm{C}$ \\
\hline
\end{tabular}

Mgr inż. Michał Baranowski - Instytut Mechaniki Precyzyjnej, dr inż. Dorota Moszczyńska, inż. Tomasz Panasiuk - Politechnika Warszawska.

Autor korespondencyjny/Corresponding author: michal.baranowski@imp.edu.pl 


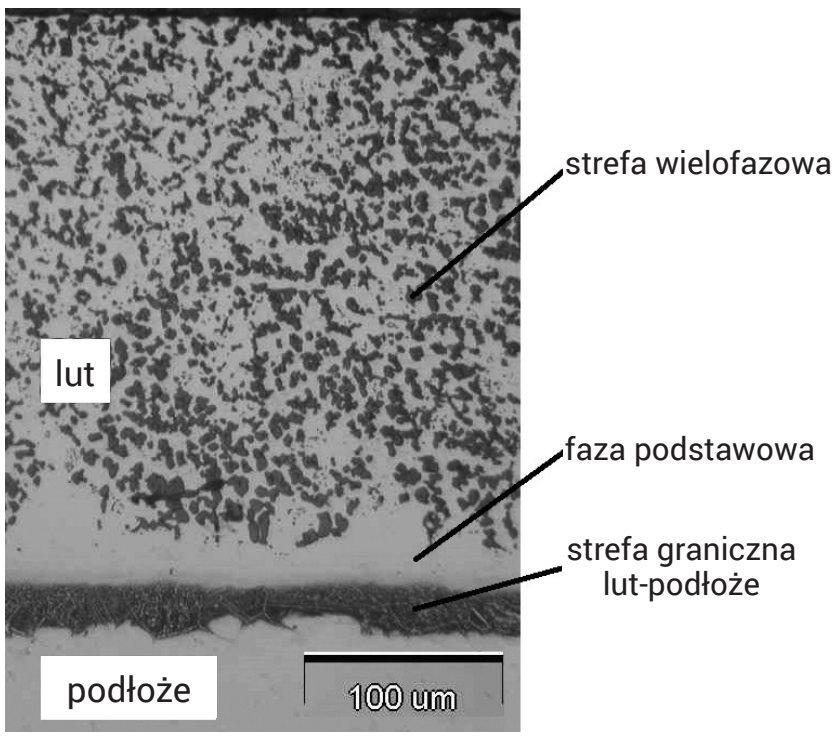

Rys. 1. Połączenie lutowane Hastelloy $X$ - Palnicro $36 \mathrm{M}$ Fig. 1. Hastelloy $X-$ Palnicro $36 \mathrm{M}$ brazed joint

\section{Materiały i eksperyment}

W pracy badaniom poddano połączenie powstałe w procesie lutowania w piecu próżniowym. Temperatura lutowania oraz czas wytrzymania w tej temperaturze wyniosły odpowiednio $995^{\circ} \mathrm{C}$ i 60 minut. W procesie lutowania zastosowano lut Palnicro $36 \mathrm{M}$ w postaci folii o grubości $0,05 \mathrm{~mm}$, którego skład chemiczny przedstawiono w tablicy I. Podłożem był superstop niklu Hastelloy X, w którego składzie brakuje pierwiastków odpowiedzialnych za wydzielenia $\gamma^{\prime}$ $\left(\mathrm{Ni}_{3}(\mathrm{AlTi})\right)$ i $\mathrm{y}^{\prime \prime}\left(\mathrm{Ni}_{3} \mathrm{Nb}\right)$. Skład chemiczny materiału podłoża został przedstawiony w tablicy II.

Tablica II. Skład chemiczny stopu Hastelloy X, \% wag. [15] Table II. Chemical composition of Hastelloy X, wt. \% [15]

\begin{tabular}{|c|c|c|c|c|c|c|c|c|}
\hline $\mathbf{N i}$ & Cr & Fe & Mo & Co & W & C & Mn & Si \\
\hline 47 & 22 & 18 & 9 & 1,5 & 0,6 & 0,1 & 1 & 1 \\
\hline
\end{tabular}

Do identyfikacji faz w strefie granicznej wykorzystano metodę dyfrakcji rentgenowskiej XRD (ang. X-ray diffraction). Analizę dyfrakcyjną obszaru strefy granicznej wykonano po usunięciu strefy wielofazowej i fazy podstawowej (szlifowanie, polerowanie i trawienie). Obserwacje przygotowywanej próbki wykonywano za pomocą mikroskopu świetlnego Nikon Eclipse LV150.

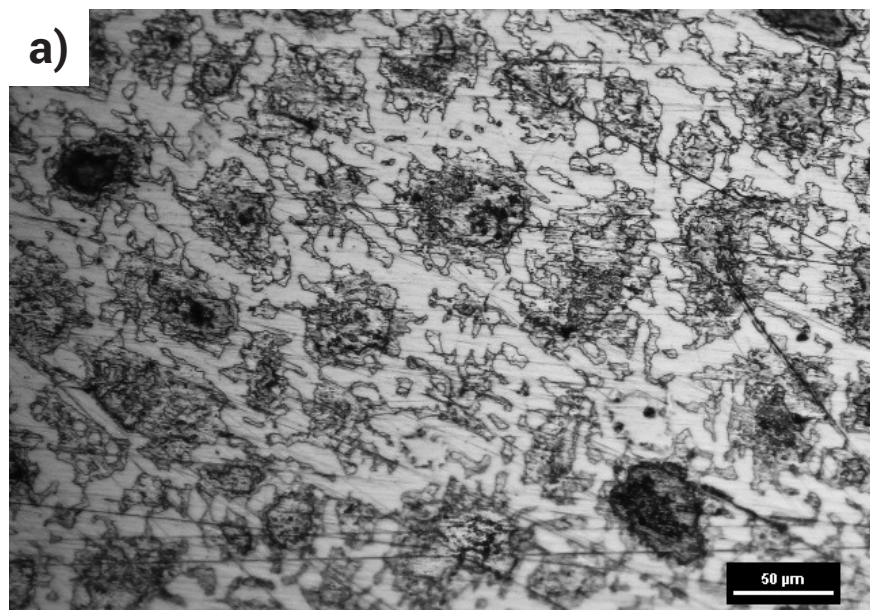

Analizę fazową przeprowadzono za pomocą dyfraktometru rentgenowskiego D8 DISCOVER Serii 2 firmy Bruker AXS, który jest wyposażony w lampę miedzianą. Parametry pomiaru były następujące: napięcie - $40 \mathrm{kV}$, prąd - $30 \mathrm{~mA}$, zakres kątowy $2 \Theta$ - od 10 do 120 , krok $\Delta 2 \Theta-0,025$, czas zliczania - $5 \mathrm{~s}$

W ramach identyfikacji poszczególnych faz wykonano także pomiar składu chemicznego w strefie granicznej metodą EDS (ang. Energy Dispersive Spectroscopy). Zobrazowanie badanej strefy oraz pomiar składu chemicznego wykonano za pomocą skaningowego mikroskopu elektronowego HITACHI SU8000.

\section{Wyniki i ich dyskusja}

Różnice pomiędzy poszczególnymi strefami połączenia lutowanego po wypolerowaniu i wytrawieniu są wyraźnie widoczne. Mikrostrukturę strefy wielofazowej z licznymi wydzieleniami przedstawiono na rysunku 2a. Badania metodą XRD wykonano w strefie granicznej, której mikrostruktura została przedstawiona na rysunku $2 \mathrm{~b}$.

Dyfraktogram wykonany dla strefy granicznej przedstawiono na rysunku 3. Stwierdzono występowanie w badanej strefie następujących faz:

- molibden nikiel $\left(\mathrm{Mo}_{1,08} \mathrm{Ni}_{2,92}\right)$,

- tetrataenite NiFe,

- chrom nikiel (CrNi),

- borek chromu $\mathrm{Cr}_{5} \mathrm{~B}_{3}$.

Dodatkowo analiza zapisów dyfrakcyjnych wskazuje na możliwość występowania dwóch dodatkowych faz:

- Bor chrom nikiel $\mathrm{Cr}_{3} \mathrm{NiB}_{6}$,

- Molibden nikiel krzem Mo6 $\left(\mathrm{Ni}_{0,75} \mathrm{Si}_{0,25}\right)_{7}$.

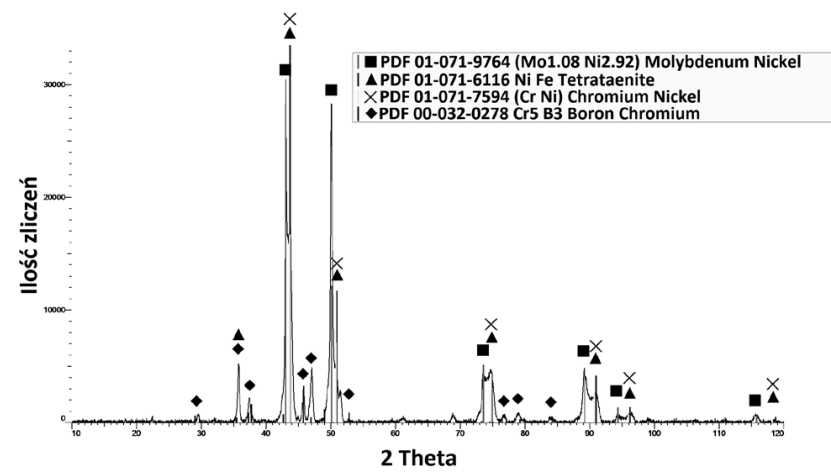

Rys. 3. Dyfraktogram dla strefy granicznej

Fig. 3. X-ray pattern for phase boundary zone

Rys. 2. Mikrostruktura połączenia lutowanego Hastelloy X - Palnicro 36M: a) strefa wielofazowa, b) strefa graniczna Fig. 2. Microstructure of Hastelloy $X$ - Palnicro $36 \mathrm{M}$ brazed joint: a) multiphase zone, b) phase boundary zone 
Obserwacje przy użyciu mikroskopu SEM ujawniły dwa rodzaje wydzieleń, które dzielą strefę graniczną na dwa różne obszary. Pierwsze $z$ nich są to drobne, ciemne wydzielenia (rys. 4a). Zlokalizowane są w badanej strefie w materiale, który uległ stopieniu podczas powstawania połączenia, a także we fragmentach ziaren stopu Hastelloy X bezpośrednio stykających się z fazą ciekłą.

Za pomocą SEM z wykorzystaniem techniki EDS określono skład chemiczny w punktach zaznaczonych na rysunku 4a. Pomiary wykonano w wydzieleniach oraz w osnowie. Dla porównania uzyskanych wyników analizy rentgenowskiej, obliczono udział masowy pierwiastków ze wzoru stechiometrycznego dla związku międzymetalicznego $\mathrm{Cr}_{3} \mathrm{NiB}_{6}$. Wyniki przedstawiono na rysunkach 4b i 4c oraz w tablicy III.

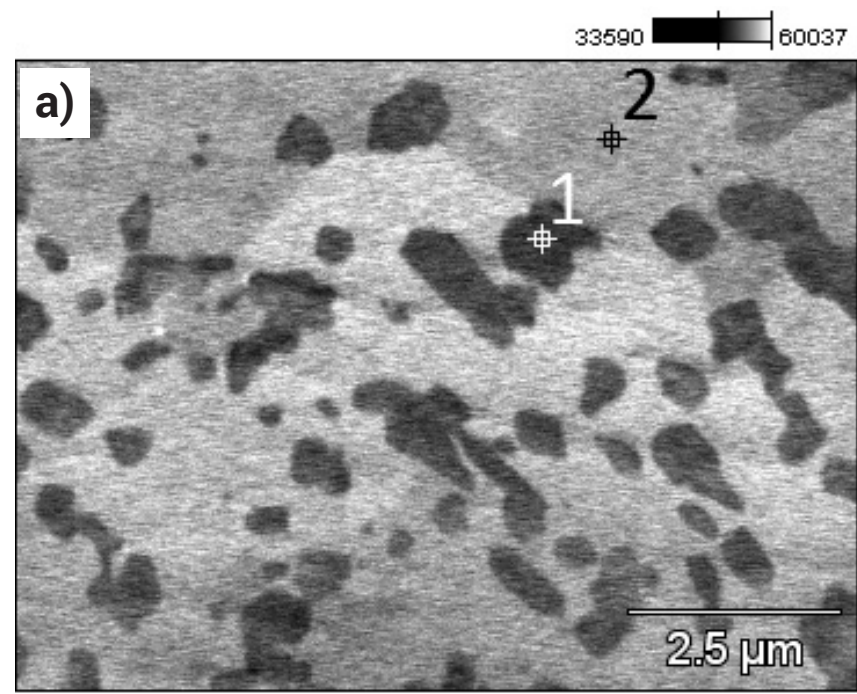

b)

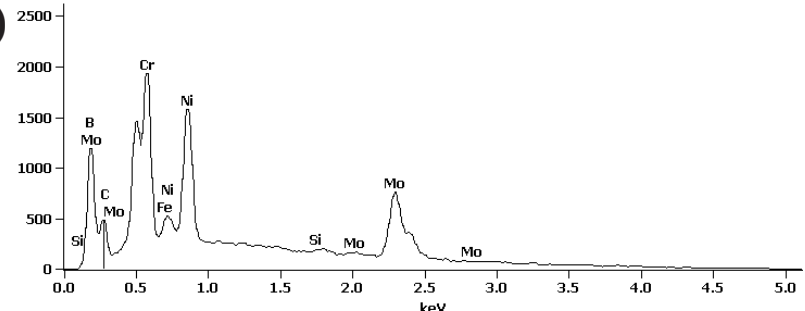

c)

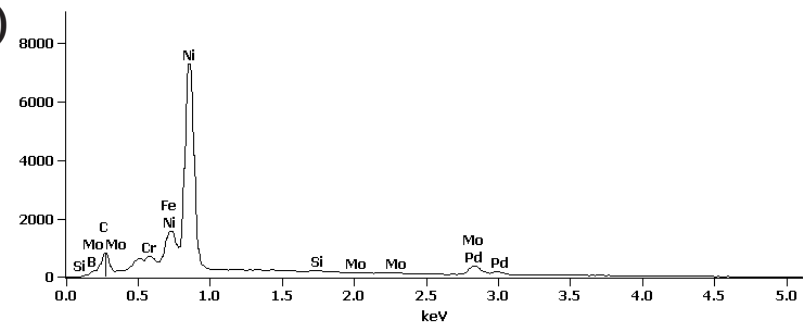

Rys. 4. Wyniki SEM EDS dla wydzieleń w strefie granicznej: a) obraz analizowanego obszaru - ciemne wydzielenia w lucie, b) pomiar EDS dla punktu 1, c) pomiar EDS dla punktu 2

Fig. 4. SEM EDS results for precipitations in phase boundary zone: a) image of the analyzed area - dark precipitations in brazing filler material, b) EDS measurement for point 1, c) EDS measurement for point 2
W ciemnych wydzieleniach zarejestrowano wzrost zawartości boru, chromu i molibdenu w porównaniu z osnową. Zawartość chromu w tych wydzieleniach jest bliska zawartości obliczonej dla związku międzymetalicznego $\mathrm{Cr}_{3} \mathrm{NiB}_{6}$. Wynik dla boru w wydzieleniach różni się z wartością obliczoną, jednakże pomiar dla tego pierwiastka metodą EDS obarczony jest dużym błędem dla badanego połączenia. Bor jest pierwiastkiem lekkim i w otoczeniu pierwiastków ciężkich jego pomiar jest ograniczony. Dodatkowo linia Ka dla boru pokrywa się z linią M dla molibdenu. Stwierdzenie występowania piku pochodzącego od boru wskazuje jedynie na jego obecność w badanym miejscu.

Spadek zawartości w ciemnych wydzieleniach w stosunku do osnowy zarejestrowano dla niklu i żelaza. Wartość jaką uzyskano dla niklu w wydzieleniach jest również mniejsza niż wartość obliczona dla związku międzymetalicznego $\mathrm{Cr}_{3} \mathrm{NiB}_{6}$, jednak różnica w porównaniu do osnowy jest znacznie mniejsza. W badanym obszarze ujawniono również inne pierwiastki m.in. Mo, $\mathrm{Fe}$ i Si.

Możliwość powstania fazy $\mathrm{Cr}_{3} \mathrm{NiB}_{6}$ podczas lutowania potwierdza trójskładnikowy układ równowagi fazowej Ni-Cr-B (rys. 5). W zakresie temperatury $800 \div 1000{ }^{\circ} \mathrm{C}, \mathrm{w}$ którym odbywa się proces technologiczny spajania, obserwuje się związek międzymetaliczny $\mathrm{Cr}_{3} \mathrm{NiB}_{6}[16]$.

Pomiar składu chemicznego metodą EDS pokazuje, że ciemne wydzielenia nie są związkiem międzymetalicznym $\mathrm{Cr}_{3} \mathrm{NiB}_{6}$. Uzyskane wyniki wskazują na obecność fazy bardziej złożonej, jednakże dopuszczają możliwość powstania innej fazy na bazie związku międzymetalicznego $\mathrm{Cr}_{3} \mathrm{NiB}_{6}$ wzbogaconej dodatkowymi pierwiastkami.

Przesuwając się dalej w głąb materiału rodzimego, zarejestrowano drugie z wydzieleń, które przedstawiono na rysunku 6a. Są to większe, jasne wydzielenia, znajdujące się w podłożu na granicy ziaren w obszarze strefy granicznej.

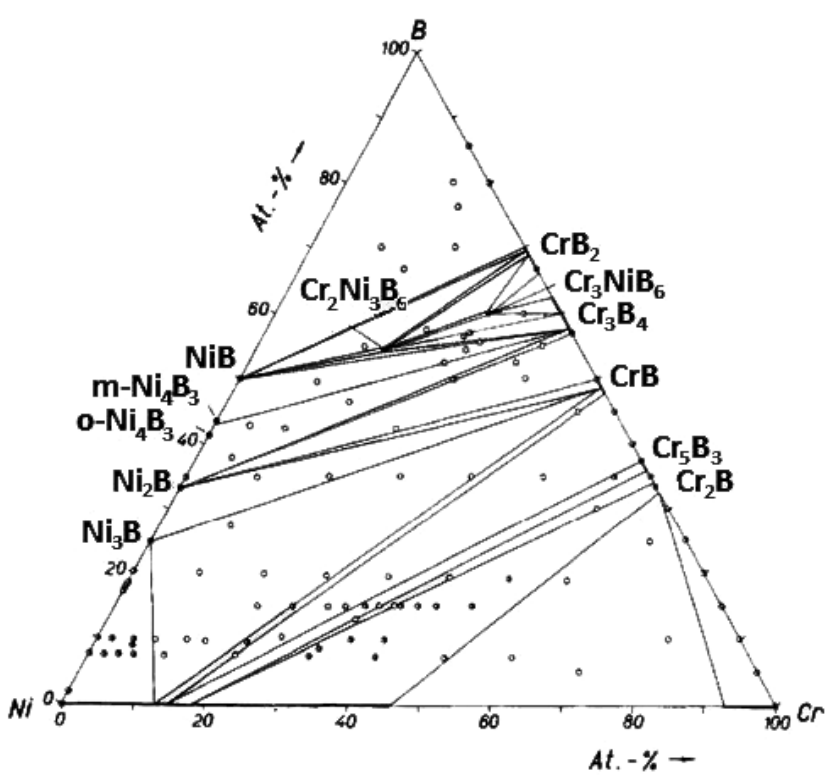

Rys. 5. Układ równowagi fazowej Ni-Cr-B w temperaturze $1000^{\circ} \mathrm{C}$ [16] Fig. 5. The ternary system Ni-Cr-B in temperature $1000^{\circ} \mathrm{C}[16]$

Tablica III. Skład chemiczny określonych punktów strefy granicznej (ciemne wydzielenia), \% wag.

Table III. Chemical composition of selected points of the phase boundary zone (dark precipitations), wt. \%

\begin{tabular}{|c|c|c|c|c|c|c|c|c|}
\hline & B-K & C-K & Si-K & Cr-L & Fe-L & Ni-L & Mo-L & Pd-L \\
\hline P-t 1 & 2,2 & 0,8 & 0,3 & 54,6 & 4,4 & 12,6 & 25,1 & - \\
\hline P-t 2 & 0,3 & 0,8 & 0,4 & 12,4 & 12,8 & 49,3 & 1,1 & 22,8 \\
\hline Cr $_{3}$ NiB $_{6}{ }^{* *}$ & 23 & - & - & 56 & - & 21 & - & - \\
\hline \\
* Skład procentowy masowy uzyskany z pomiaru metodą EDS \\
* Skład procentowy masowy obliczony ze wzoru stechiometrycznego \\
\hline
\end{tabular}


Tablica IV. Skład chemiczny określonych punktów strefy granicznej (jasne wydzielenia), \% wag.

Table IV. Chemical composition of selected points of the phase boundary zone (bright precipitations), wt. \%

\begin{tabular}{|c|c|c|c|c|c|c|c|}
\hline & B-K & C-K & Si-K & Cr-L & Fe-L & Ni-L & Mo-L \\
\hline P-t 1* & 0,0 & 1,4 & 2,5 & 15,9 & 8,4 & 23,2 & 48,6 \\
\hline P-t 2* & 0,0 & 0,6 & 0,5 & 21,9 & 20,0 & 49,4 & 7,6 \\
\hline Mo $_{6}\left(\mathrm{Ni}_{0,75} \mathbf{S i}_{0,25}\right)_{7}^{* *}$ & - & - & 5 & - & - & 33 & 62 \\
\hline $\begin{array}{l}\text { * Skład procentowy masowy uzyskany z pomiaru metodą EDS } \\
\text { * Skład procentowy maswy obliczony ze wzoru stechiometrycznego }\end{array}$ \\
\hline
\end{tabular}

Analogicznie jak w przypadku ciemnych wydzieleń wyznaczono skład chemiczny za pomocą SEM z wykorzystaniem techniki EDS, który porównano z udziałem masowym pierwiastków obliczonym ze wzoru stechiometrycznego

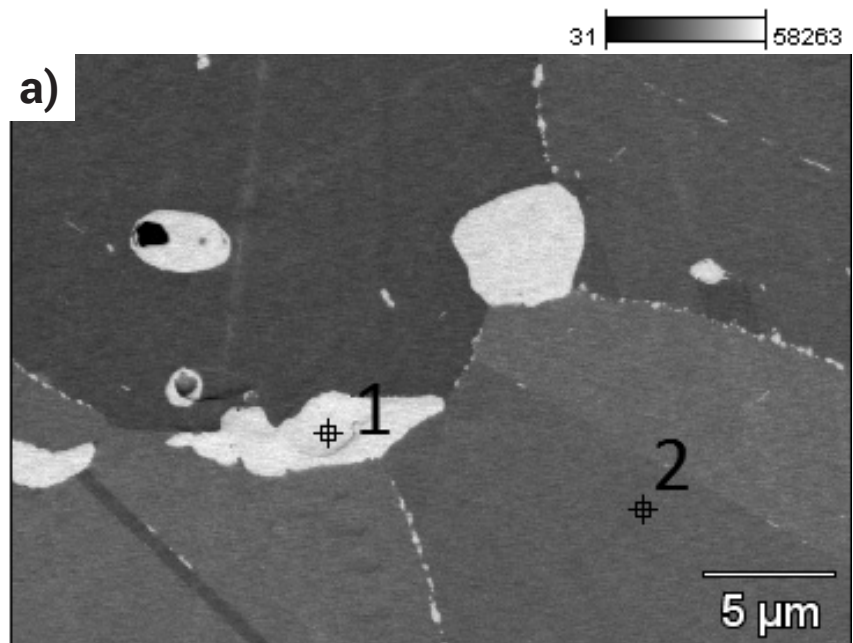

b) 3000

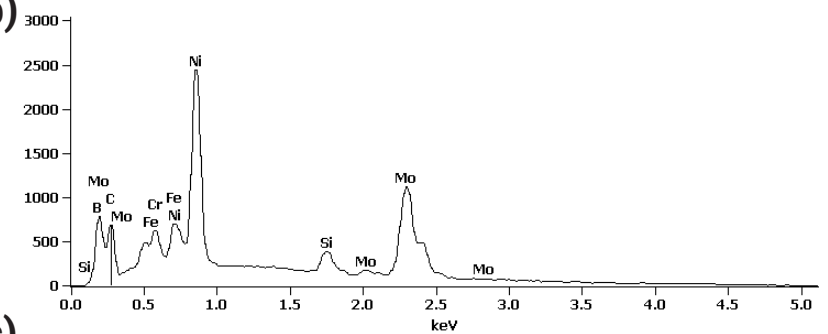

C)

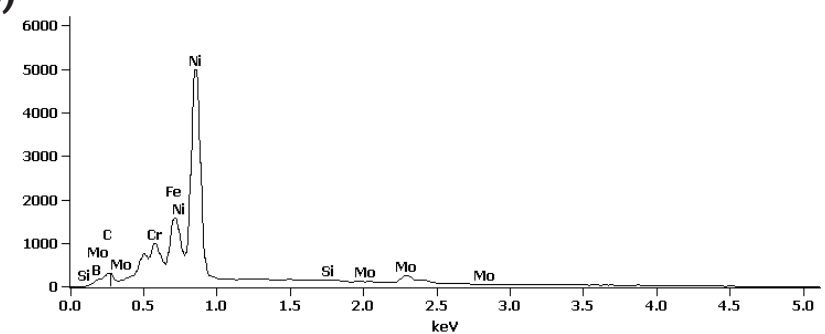

Rys. 6. Wyniki SEM EDS dla wydzieleń w strefie granicznej: a) obraz analizowanego obszaru - jasne wydzielenia w podłożu, b) pomiar EDS dla punktu 1, c) pomiar EDS dla punktu 2

Fig. 6. SEM EDS results for precipitations in phase boundary zone: a) image of the analyzed area - bright precipitations in base material, b) EDS measurement for point 1,c) EDS measurement for point 2 dla związku międzymetalicznego $\mathrm{Mo}_{6}\left(\mathrm{Ni}_{0,75} \mathrm{Si}_{0,25}\right)_{7}$. Wyniki pomiaru składu chemicznego przedstawiono na rysunkach $6 \mathrm{~b}$ i $6 \mathrm{c}$ oraz w tablicy IV.

W jasnych wydzieleniach w porównaniu z osnową zarejestrowano wzrost zawartości molibdenu i krzemu. Zmniejszyła się natomiast zawartość żelaza, chromu i niklu. W stosunku do zawartości Mo, Ni i Si obliczonych dla związku międzymetalicznego $\mathrm{Mo}_{6}\left(\mathrm{Ni}_{0,75} \mathrm{Si}_{0,25}\right)_{7} \mathrm{w}$ pomiarze EDS w miejscu wydzielenia stwierdzono mniejsze wartości dla tych pierwiastków. W jasnych wydzieleniach zarejestrowano również C, Cr i Fe.

Analiza literaturowa wskazuje na podobieństwo jasnych wydzieleń do fazy $\mathrm{Mo}_{6}\left(\mathrm{Ni}_{0,75} \mathrm{Si}_{0,25}\right)_{7}$ ujawnionej w stopie IC6 (Ni-Al-Mo-B), którą przedstawiono na rysunku 7 . W stopie IC6 wzbogaconym o $0,10 \div 0,20 \%$ Si i 0,12\% Y pojawiły się jasne wydzielenia w obszarze międzydendrytycznym. Analiza TEM wykazała, że jest to $\mathrm{Mo}_{6}\left(\mathrm{Ni}_{0,75} \mathrm{Si}_{0,25}\right)_{7}[17]$.

Ze względu na bardziej złożony skład chemiczny jasnych wydzieleń stwierdza się, że nie są one związkiem międzymetalicznym $\mathrm{Mo}_{6}\left(\mathrm{Ni}_{0,75} \mathrm{Si}_{0,25}\right)_{7}$. Jednak analiza literaturowa oraz stosunkowo nieduża różnica w składzie chemicznym nie wyklucza występowania fazy na bazie $\mathrm{Mo}_{6}\left(\mathrm{Ni}_{0,75} \mathrm{Si}_{0,25}\right)_{7}$ wzbogaconej o dodatki C, Cr i Fe.

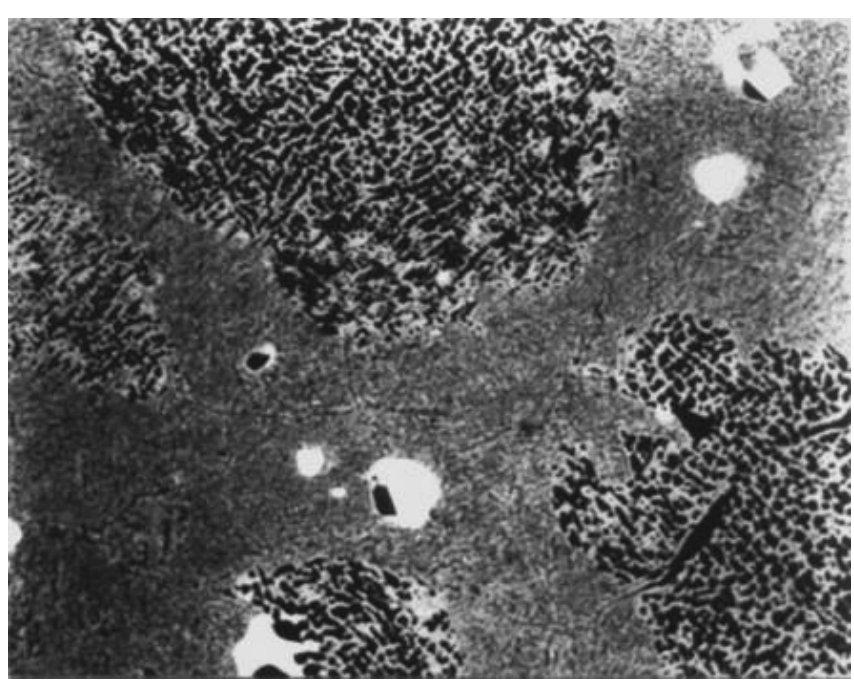

Rys. 7. $\mathrm{Mo}_{6}\left(\mathrm{Ni}_{0,75} \mathrm{Si}_{0,25}\right)_{7} \mathrm{~W}$ stopie IC6 z dodatkiem $0,10 \div 0,20 \% \mathrm{Si}$ i $0,12 \%$ Y [17]

Fig. 7. $\mathrm{Mo}_{6}\left(\mathrm{Ni}_{0.75} \mathrm{Si}_{0.25}\right)_{7}$ in alloy IC6 with addition of $0.10 \div 0.20 \mathrm{wt} \% \mathrm{Si}$ and $0.12 \mathrm{wt} \% \mathrm{Y}$ [17]

\section{Podsumowanie}

W ramach niniejszej pracy scharakteryzowano strefę graniczną połączenia Hastelloy X - Palnicro 36M. W badanym obszarze ujawniono dwa rodzaje wydzieleń powstałych w osnowie obejmującej obszar podłoża w stanie stałym i ciekłego lutu. Uzyskano złożony skład fazowy dla strefy granicznej połączenia Hastelloy X - Palnicro 36M.

Analiza dyfrakcyjna umożliwiła zidentyfikowanie w strefie granicznej faz utworzonych przez: molibden nikiel $\left(\mathrm{Mo}_{1,08} \mathrm{Ni}_{2,92}\right)$, tetrataenite NiFe, chrom nikiel (CrNi), bor chrom $\mathrm{Cr}_{5} \mathrm{~B}_{3}$. Wyniki uzyskane metodami XRD oraz EDS wskazały również na możliwość występowania w strefie granicznej faz na bazie związków międzymetalicznych $\mathrm{Cr}_{3} \mathrm{NiB}_{6} \mathrm{i} \mathrm{Mo}_{6}\left(\mathrm{Ni}_{0,75} \mathrm{Si}_{0,25}\right)_{7}$. 


\section{Literatura}

[1] Babul T., Jakubowski J., Kopeć J., et al: Lutowanie próżniowe uszczelnień ulowych w aparatach kierujących wykonanych ze stopów Hastelloy i Inconel z zastosowaniem lutu NiCrSiB, Przegląd Spawalnictwa, R. 79, nr 9, 2007, s.124-129.

[2] Dul I.: Zastosowanie i przetwarzanie stopów niklu w przemyśle lotniczym, Przegląd Spawalnictwa R. 81, nr 7-8, 2009, s. 67-73.

[3] Dul I., Kopeć J., Poradka A., et al: Wpływ wybranych czynników technologicznych na proces lutowania próżniowego stopów Ni i stali wysokostopowej 18-8, Przegląd Spawalnictwa R. 81, nr 10, 2009, s. 77-80.

[4] Dul I., Jakubowski J., Senkara J.: Spajanie zaawansowanych stopów Ni w przemyśle lotniczym, Rudy i Metale Nieżelazne, 2011, s. 397-405.

[5] Baranowski M., Jakubowski J.: Lutowność wybranych nadstopów niklu, Przegląd Spawalnictwa R. 86, nr 7, 2014, s. 3-8.

[6] Eng R.D., Ryan E.J., Doyle J.R.: Nickel-base brazing filler metals for aircraft gas turbine application, Weld J, Miami; United States, 1977, 56:10.

[7] Schwartz M.M.: Brazing, 2nd Editio, ASM International, Materials Park Ohio, 2003

[8] Sulzer Metco Braze Materials Guide, 2011.

[9] Palnicro Data Sheet, 2013, http://www.morganbrazealloys.com/media/ 1586/wesgo_metals_palniro_36m.pdf. Accessed 19 Oct 2017.

[10] Bober M., Jakubowski J., Senkara J.: Badania zdolności kapilarnych lutu BNi2 metodą zmiennej szczeliny lutowniczej, Przegląd Spawalnictwa, R. 88, nr 9, 2016, s. 87-90, doi: 10.26628/PS.V88I9.663.
[11] Edelmann F.: Characterization of the behavior of Palnicro brazing alloy for stainless steel joints, McGill University, 2005.

[12] Turner D.: Évolution microstructurale des joints brasés sur l'inconel 718 avecles alliages BNi-2 et PALNICRO, École de technologie supérieure, 2005.

[13] Rokvam M.: Caractérisation De Microstructures De Joints Brasés Avec Les Alliages Bcu-1, Bag-13a, Bau-4, Bau-6, Bni-1a, Bni-2, Bni-3 Et Palnicro 36M Ayant Pour Métal De Base Un Superalliage Base Nickel, École de technologie supérieure, 2011.

[14] Dul I., Senkara J., Bober M., Jakubowski J.: Wpływ wysokotemperaturowego wygrzewania próżniowego na lutowność Inconelu 718 lutem Palnicro 36, Przegląd Spawalnictwa R. 85, nr 9, 2013, s. 15-19.

[15] Hastelloy X Composition, 2017, http://www.espimetals.com/index.php/ technical-data/82-Hastelloy X Composition, Accessed 19 Oct 2017.

[16] Lugscheider E., Knotek O., Reimann H.: Das Dreistoffsystem NickelChrom-Bor, Monatshefte für Chemie 105 s. 80-90, 1974, doi: 10.1007/ BF00911291

[17] Xiao C.B., Han Y.F.: Effect of silicon on microstructure and stress rupture properties at $1100^{\circ} \mathrm{C}$ of yttrium modified Ni-Al-Mo-B alloy IC6, Journal of Materials Science vol. 36, 2001, pp.1027-1030, doi: 10.1023/A:1004848528582 


\title{
Wpływ aktywacji powierzchni aluminium 7075 na wytrzymałość połączenia klejowego
}

\author{
The investigation of influence of surface activation \\ of aluminum 7075 on strength of bonded joint
}

\section{Streszczenie}

W artykule przedstawiono wyniki badań wytrzymałości statycznej na ścinanie połączeń klejowych zakładkowych wykonanych ze stopu aluminium 7075 . Badania miały charakter porównawczy i dotyczyły przebadania wpływu aktywacji powierzchni klejonej przy zastosowaniu plazmy niskotemperaturowej z próbkami niepoddanymi aktywowaniu. Zastosowano 3 rodzaje materiałów adhezyjnych. Na podstawie przeprowadzonych badań stwierdzono wzrost swobodnej energii powierzchniowej dla próbek modyfikowanych plazmą niskotemperaturową oraz dla 2 z 3 badanych klejów wzrost wytrzymałości połączenia.

Słowa kluczowe: plazma niskotemperaturowa; aktywacja powierzchni; połączenie klejowe; aluminium 7075

\begin{abstract}
The paper presents the results of the static strength test on shear adhesion bonded joints made of aluminum alloy 7075. The tests were of a comparative nature and examined the effect of surface activation using low temperature plasma with non-activated samples. Three types of adhesives were used. Based on the studies, the increase of free surface energy for low temperature plasma samples and for 2 of the 3 tested adhesives increased the strength of the joint were observed.
\end{abstract}

Keywords: low temperature plasma; surface activation; adhesion bonded joint; aluminum alloy 7075

\section{Wstęp}

Połączenia adhezyjne znajdują coraz szersze zastosowanie w wielu gałęziach przemysłu. Jest to związane $z$ wieloma zaletami takich połączeń, do których przede wszystkim należy możliwość łączenia materiałów różnoimiennych, możliwość doboru kleju do warunków eksploatacji połączenia, przenoszenie obciążeń przez całą powierzchnię złącza, a także szczelność połączenia. Do wad w szczególności należy konieczność zachowania odpowiedniego reżimu procesu technologicznego wytwarzania połączenia klejowego, w zależności od stosowanych materiałów występuje zwykle konieczność przygotowania powierzchni łączonych odpowiednimi technikami [5,13]. Badacze wskazują również na konieczność uwzględnienia środowiska użytkowania, ze względu na wrażliwość połączenia klejowego na oddziaływanie podwyższonej temperatury $[6,8]$. Metody przygotowania powierzchni można zasadniczo podzielić na 2 grupy. Do grupy 1 należą metody, których celem jest rozwinięcie powierzchni, co zwykle jest też związane z uzyskaniem powierzchni chropowatej, czego efektem jest zwiększony udział adhezji mechanicznej. Rozwinięcie powierzchni jest zwykle realizowane przy udziale mechanicznych metod obróbki powierzchni narzędziami nasypowymi lub metodami obróbki strumieniowo-ściernej [6,9]. Niestety należą one do metod pracochłonnych i komplikujących proces wytwórczy. Do drugiej grupy metod należą wszelkie metody chemiczne przygotowania powierzchni, czego efektem jest aktywacja powierzchni objawiająca się zwykle zwiększeniem polarności. Do metod chemicznych zaliczamy modyfikację powierzchni przez zastosowanie trawienia roztworami trawiącymi na bazie kwasów i ich mieszanin, a także nakładanie środków proadhezyjnych (np. związków silanowych), których celem jest uzyskanie na powierzchniach łączonych korzystnych warunków sprzyjających zwiększeniu adhezji tzw. właściwej. Metody chemiczne ze względu na występowanie różnych substancji chemicznych, o różnym stopniu szkodliwości zarówno dla otoczenia, jak i dla człowieka wymuszają stosowanie skomplikowanych instalacji procesowych, co również podraża całościowo proces wytwórczy.

Prezentowany artykuł dotyczy zbadania możliwości aktywowania powierzchni stopu aluminium 7075 przy zastosowaniu plazmy niskotemperaturowej. Plazma, ze względu na odmienne od fazy stałej, ciekłej i gazowej właściwości, powstaje w temperaturach, w których średnie energie kinetyczne cząstek przekraczają wartość potencjału jonizacyjnego.

Dr hab. inż. Zbigniew Zimniak, prof. PWr; dr inż. Roman Wróblewski - Politechnika Wrocławska.

Autor korespondencyjny/Corresponding author. zbigniew.zimniak@pwr.edu.pl 
Plazma niskotemperaturowa jest najczęściej gazem zjonizowanym w niewielkim stopniu, o dużej lub bardzo dużej zawartości cząstek neutralnych, w skład której wchodzą jądra atomów, cząstki elementarne, a także, atomy, ich jony oraz cząsteczki. Zastosowanie takiej plazmy pozwala na zwiększenie energii powierzchniowej łączonych materiałów, co przyczyni się do uzyskania dobrej jakości spoiny klejowej. Plazma tego typu stosowana była do tej pory do obróbki powierzchni tworzyw sztucznych w celu otrzymywania specjalnych własności potrzebnych do procesów klejenia, czyszczenia czy poprawy zwilżalności lub ścieralności $[3 \div 4,7,10 \div 12]$.

Proces aktywacji powierzchni przy pomocy plazmy niskotemperaturowej jest procesem relatywnie łatwym do zastosowania, w minimalnym stopniu komplikujący proces wytwórczy. Aktywacja powierzchni z wykorzystaniem plazmy niskotemperaturowej jest już stosowana do aktywacji powierzchni materiałów polimerowych, ale w odniesieniu do metali na chwilę obecną wykorzystywana jest niewielkim stopniu.

\section{Metodyka badań}

Próbki użyte do badań zostały wykonane ze stopu aluminium 7075, o wymiarach $25 \times 60 \times 2 \mathrm{~mm}$. Po zdjęciu folii ochronnej próbki oczyszczono alkoholem etylowym. W tablicy I przedstawiono skład chemiczny stopu 7075, tabelę opracowano na podstawie certyfikatu materiału.

W tablicy II zebrano wybrane własności mechaniczne stopu 7075.

Do pomiarów kąta zwilżania powierzchni stopu 7075 oraz do wyznaczania swobodnej energii powierzchniowej (SEP) zastosowano goniometr Krüss DSAHT1200 wraz z oprogramowaniem firmowym DSA3. Do pomiarów wybrano 4 ciecze pomiarowe o znanej wartości energii powierzchniowej oraz o znanych wartościach części polarnej i części dyspersyjnej. Do badań użyto:

- wody destylowanej, dla której: swobodna energia powierzchniowa wynosi $\gamma_{w}=72,8\left[\mathrm{~mJ} / \mathrm{m}^{2}\right]$, składowa dyspersyjna wynosi $\gamma_{w D}=21,8\left[\mathrm{~mJ} / \mathrm{m}^{2}\right]$, składowa polarna wynosi $\gamma_{\mathrm{wP}}=51,0\left[\mathrm{~mJ} / \mathrm{m}^{2}\right]$;

- dijodometanu, dla którego: swobodna energia powierzchniowa wynosi $\gamma_{w}=50,8\left[\mathrm{~mJ} / \mathrm{m}^{2}\right]$, składowa dyspersyjna wynosi $\gamma_{w D}=48,5\left[\mathrm{~mJ} / \mathrm{m}^{2}\right]$, składowa polarna wynosi $\gamma_{\mathrm{wP}}=2,3\left[\mathrm{~mJ} / \mathrm{m}^{2}\right]$;

- glikolu etylowego, dla którego: swobodna energia powierzchniowa wynosi $\gamma_{w}=48,0\left[\mathrm{~mJ} / \mathrm{m}^{2}\right]$, składowa dyspersyjna wynosi $\gamma_{w D}=29,0\left[\mathrm{~mJ} / \mathrm{m}^{2}\right]$, składowa polarna wynosi $\gamma_{\mathrm{wP}}=19,0\left[\mathrm{~mJ} / \mathrm{m}^{2}\right]$;

- formamidu, dla którego: swobodna energia powierzchniowa wynosi $\gamma_{w}=56,90\left[\mathrm{~mJ} / \mathrm{m}^{2}\right]$, składowa dyspersyjna wynosi $\gamma_{w D}=23,50\left[\mathrm{~mJ} / \mathrm{m}^{2}\right]$, składowa polarna wynosi $\gamma_{w P}=33,40\left[\mathrm{~mJ} / \mathrm{m}^{2}\right][15]$.
Do wytworzenia jednozakładkowych połączeń użyto blachy ze stopu aluminium 7075, dla których przewidziano 2 warianty przygotowania powierzchni. Jeden wariant przewidywał przygotowanie próbek tylko przez ich odtłuszczenie, drugi natomiast przewidywał przygotowanie powierzchni przez aktywację plazmą niskotemperaturową. Modyfikacja przy zastosowaniu plazmy niskotemperaturowej była prowadzona przy następujących parametrach: moc urządzenia $300 \mathrm{~W}$, napięcie pracy $18 \mathrm{kV}$, przepływ argonu $16 \mathrm{l} / \mathrm{min}$ i stały czas ekspozycji wynoszący $60 \mathrm{~s}$. Zasadę działania urządzenia do wytwarzania plazmy pokazano na rysunku 1.

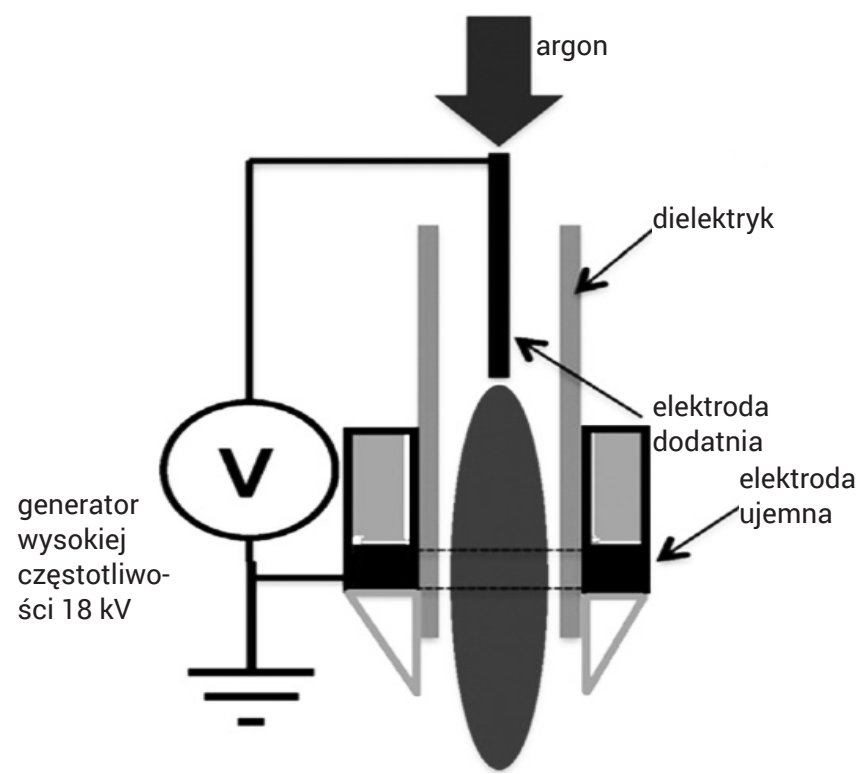

Rys. 1. Schemat urządzenia do wytwarzania plazmy niskotemperaturowej

Fig. 1. Schematic of a device for producing low temperature plasma

Wymiary wytworzonego połączenia jednozakładkowego zostały przedstawione na rysunku 2. Grubość warstwy kleju była stała i wynosiła 0,18 mm. Stała grubość warstwy została uzyskana przez zastosowanie drucików miedzianych o grubości 0,18 mm jako elementów dystansowych. W badaniach zastosowano klej przemysłowy na bazie żywicy metakrylowej - Agomet F330 oraz dwie kompozycje klejowe na bazie żywicy epoksydowej Epidian 57+60\% wag. utwardzacza PAC oraz Epidian $5+70 \%$ wag. utwardzacza PAC. Klej Agomet F330 jest klejem dwuskładnikowym, żywica+utwardzacz w postaci proszku, utwardzacza dodano w ilości 3\% wag., a klej charakteryzuje się dobrymi własnościami wytrzymałościowymi (wg danych producenta wytrzymałość na ścinanie to $33 \mathrm{MPa}$ dla stopów aluminium) [14]. Połączenia klejowe z wykorzystaniem kleju Agomet F330 były badane po upływie 24 h od momentu klejenia.

Tablica I. Skład chemiczny stopu aluminium 7075

Table I. Aluminum alloy 7075 chemical composition

\begin{tabular}{|c|c|c|c|c|c|c|c|c|}
\hline \multicolumn{10}{|c|}{ Aluminium 7075} \\
\hline Pierwiastek & $\mathrm{Si}$ & $\mathrm{Fe}$ & $\mathrm{Cu}$ & $\mathrm{Mn}$ & $\mathrm{Mg}$ & $\mathrm{Cr}$ & $\mathrm{Zn}$ & $\mathrm{Ti}$ \\
\hline Wartość zakres lub max, \% & 0,40 & 0,50 & $1,20 \div 2,00$ & 0,30 & $2,10 \div 2,90$ & $0,18 \div 0,28$ & $5,10 \div 6,10$ & 0,20 \\
\hline
\end{tabular}

Tablica II. Wybrane własności mechaniczne stopu aluminium 7075

Table II. Aluminum alloy 7075 selected mechanical properties

\begin{tabular}{|c|c|c|c|}
\hline \multicolumn{4}{|c|}{ Aluminium 7075} \\
\hline Wytrzymałość na rozciąganie $\mathbf{R}_{\mathrm{m}}, \mathbf{M P a}$ & Umowna granica plastyczności $\mathbf{R}_{\mathrm{p} 0,2}, \mathbf{M P a}$ & Twardość $\mathrm{HB}$ & Wydłużenie $\mathbf{A}_{5}, \%$ \\
\hline $480 \div 540$ & $390 \div 470$ & $104 \div 157$ & $6 \div 8$ \\
\hline
\end{tabular}


Próbki, dla których do połączenia wykorzystano kompozycje klejowe na bazie żywic epoksydowych sieciowano dwuetapowo. Wstępnie $\mathrm{w}$ temp. $35^{\circ} \mathrm{C}$ przez czas $1,5 \mathrm{~h}$ i następnie kolejne $1,5 \mathrm{~h}$ w temperaturze $100{ }^{\circ} \mathrm{C}$. Połączenia klejowe były badane na maszynie wytrzymałościowej po upływie kolejnych $24 \mathrm{~h}$. Badania wytrzymałościowe wytworzonych połączeń zakładkowych były prowadzone na uniwersalnej maszynie wytrzymałościowej Tinius Olsen H25KT. Prędkość przesuwu trawersy podczas prób wynosiła $2 \mathrm{~mm} / \mathrm{min}$.
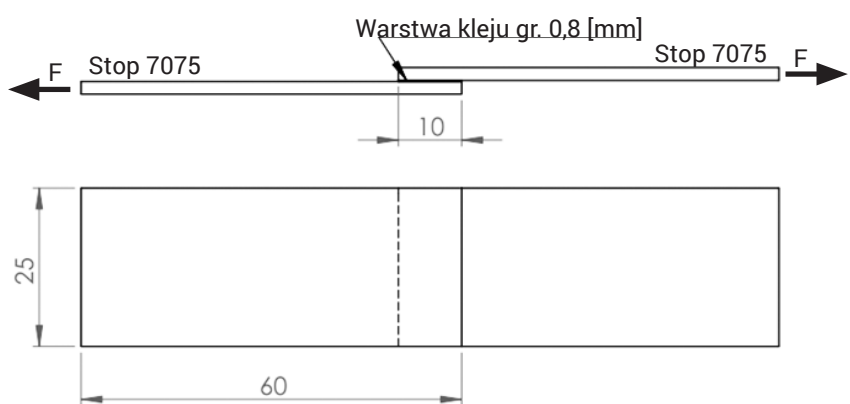

Rys. 2. Schemat próbki do badań - połączenie jednozakładkowe Fig. 2. Diagram of the test sample - one-way connection

\section{Wyniki badań}

W tabeli 3 przedstawiono uśrednione wartości energii powierzchniowej uzyskane w wyniku pomiarów kąta zwilżania wymienionymi wyżej cieczami pomiarowymi powierzchni próbek ze stopu 7075. Wartości swobodnej energii powierzchniowej zostały wyliczone metodą Owens-Wendt-Rabel-Kaelble'a (OWRK) przy zastosowaniu 4 cieczy pomiarowych [2].

Na rysunku 3 przedstawiono przekładowe zdjęcia zwilżania przez kroplę wody powierzchni stopu 7075 dla 2 wariantów przygotowania powierzchni. Na rysunku 3a przedstawiono kroplę wody zwilżającą powierzchnię nie modyfikowaną, odtłuszczoną alkoholem etylowym. Kąt zwilżania wodą dla takich warunków wyniósł $79,3^{\circ}$.

a) $\mathrm{CA}$ 니 79.3 CA [P] 79.3

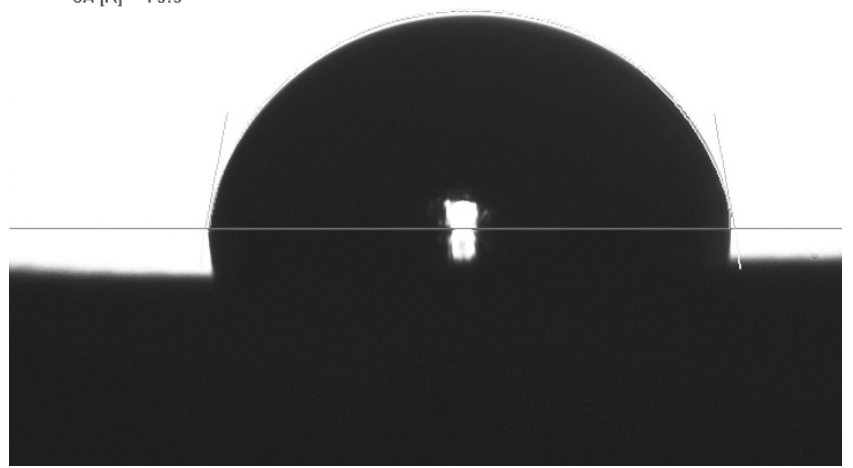

$\mathrm{Na}$ rysunku 3b przedstawiono natomiast kroplę wody zwilżającą powierzchnię odtłuszczoną alkoholem etylowym oraz dodatkowo aktywowaną działaniem plazmy niskotemperaturowej. Kąt zwilżania wodą dla takich warunków wyniósł $42,7^{\circ}$.

W wyniku działania strumieniem plazmy niskotemperaturowej zaobserwowano wzrost SEP o ok. 43\%, w tym składowej dyspersyjnej o ok. 13\% i składowej polarnej o 316\%. Znaczący wzrost SEP wskazuje, iż zaproponowana modyfikacja powierzchni działa i wpływa znacząco na zwiększenie polarności powierzchni. Należy oczekiwać, iż połączenie klejowe $z$ w ten sposób modyfikowaną powierzchnią powinny cechować się większą wytrzymałością.

$\mathrm{Na}$ podstawie przeprowadzonych badań wytrzymałościowych wytworzonych połączeń zakładkowych z zastosowaniem 2 metod przygotowania powierzchni oraz kleju Agomet F330, oraz kompozycji klejowych na bazie żywic Epidian 5, Epidian 57 oraz utwardzacza PAC otrzymano wyniki, które zestawiono na rysunku 4.

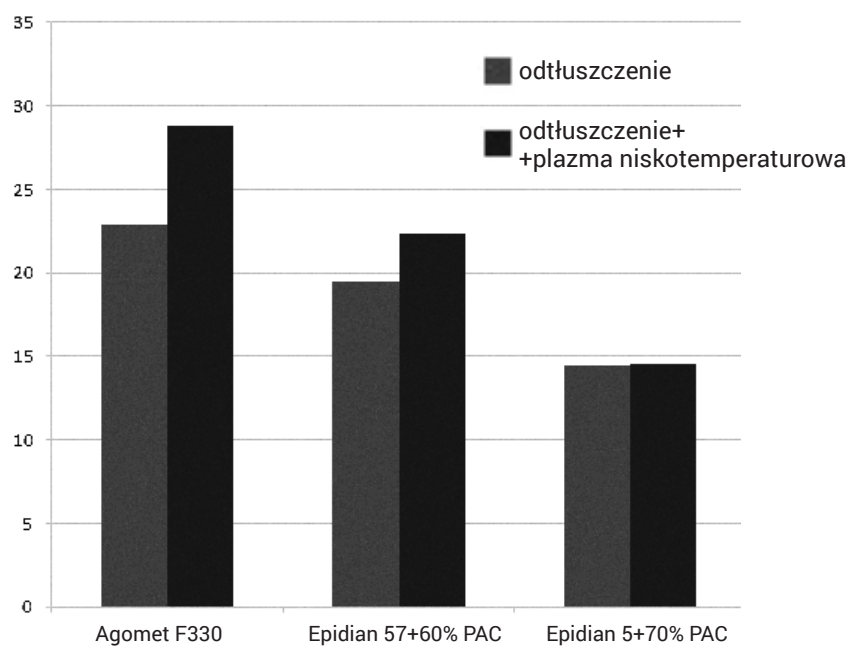

Rys. 4. Naprężenia niszczące $w$ połączeniach klejowych pracujących na ścinanie

Fig. 4. Failure stresses in shear working glued joints
CA [R] 42.7

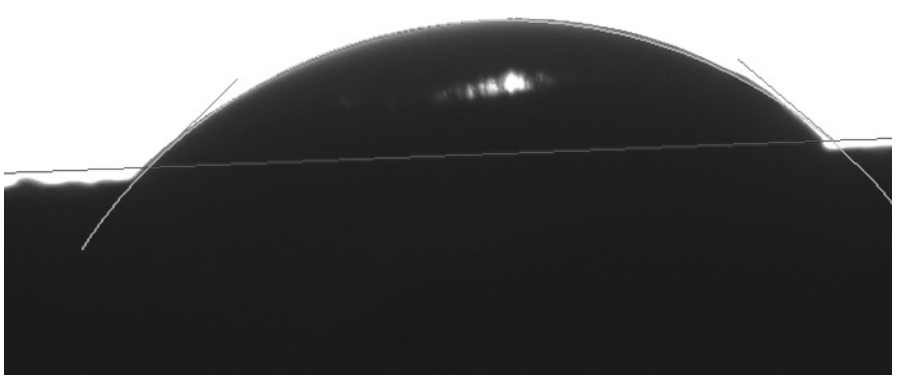

Rys. 3. Zdjęcia kropli wody zwilżającej powierzchnię stopu 7075; a) powierzchnia po odtłuszczeniu, b) powierzchnia dodatkowo aktywowana plazmą niskotemperaturową

Fig. 3. Photos of water drop dampening surface of alloy 7075 ; a) surface after degreasing, b) surface additionally activated by low temperature plasma

Tablica III. Swobodna energia powierzchniowa (SEP) i jej składowe dla stopu aluminium 7075 Table III. Free surface energy (FSE) and its components for aluminum alloy 7075

\begin{tabular}{|c|c|c|c|c|c|c|}
\hline & \multicolumn{3}{|c|}{ Aluminium 7075 po odtłuszczaniu } & \multicolumn{3}{|c|}{$\begin{array}{l}\text { Aluminium } 7075 \text { po odttuszczaniu } \\
\text { i obróbce plazmą niskotemperaturową }\end{array}$} \\
\hline & $\mathrm{SEP}\left[\mathrm{mJ} / \mathrm{m}^{2}\right]$ & $\begin{array}{c}\text { Składowa dys- } \\
\text { persyjna }\left[\mathrm{mJ} / \mathrm{m}^{2}\right]\end{array}$ & $\begin{array}{l}\text { Składowa polar- } \\
\text { na }\left[\mathrm{mJ} / \mathrm{m}^{2}\right]\end{array}$ & SEP $\left[\mathrm{mJ} / \mathrm{m}^{2}\right]$ & $\begin{array}{c}\text { Składowa dys- } \\
\text { persyjna }\left[\mathrm{mJ} / \mathrm{m}^{2}\right]\end{array}$ & $\begin{array}{l}\text { Składowa polar- } \\
\text { na }\left[\mathrm{mJ} / \mathrm{m}^{2}\right]\end{array}$ \\
\hline Wartość średnia & 37,1 & 31,6 & 5,4 & 53,2 & 36,0 & 17,1 \\
\hline
\end{tabular}




\section{Wnioski}

Na podstawie przeprowadzonych badań można sformułować następujące wnioski:

1. Stwierdzono wzrost swobodnej energii powierzchniowej dla blach stopu aluminium 7075 modyfikowanych plazmą niskotemperaturową i w stosunku do blach niemodyfikowanych wzrost ten wynosił ok. 43\%, co ważniejsze wzrost składowej polarnej wynosił $316 \%$.

2. Dla kleju Agomet oraz dla kompozycji Epidian 57+PAC zanotowano wzrost wytrzymałości połączenia. Wzrost ten wynosi ok. 25\% dla kleju Agomet F330 i ok. 15\% dla kompozycji Epidianu 57+PAC. Dla kompozycji Epidian 5+PAC nie odnotowano wzrostu wytrzymałość po zastosowaniu aktywacji powierzchni plazmą niskotemperaturową.

3. Z przeprowadzonych badań można wywnioskować, iż aktywacja powierzchni i tym samym wzrost energii powierzchniowej przekłada się na wzrost wytrzymałości połączenia klejowego, jednak w omawianym przypadku miało to odzwierciedlenie dla 2 z 3 przebadanych klejów. Zatem przed zastosowaniem aktywacji przy pomocy plazmy niskotemperaturowej w odniesieniu do konkretnego materiału i kleju należy przeprowadzić badania wstępne, aby potwierdzić celowość stosowania tej metody aktywacji.

\section{Literatura}

[1] Anagreha N., Dorn L.: Influence of low-pressure plasma treatment on adhesive bonding between polybutylene terephthalat (PBT) and aluminum, International Journal of Adhesion \& Adhesives, 25, 2005, pp. 165-172.

[2] Baldan A.: Adhesion phenomena in bonded joints, Intern. Journal of Adhesion \& Adhesives, 38, 2012.

[3] Bárdos L., Baránková H.: Cold atmospheric plasma: sources, processes, and applications, Thin Solid Films, 2010, 518, pp. 6705-6713.

[4] Gao Z., Sun J., Peng S., Yao L., Qiu Y.: Surface modification of a polyamide 6 film by He/CF4 plasma using atmospheric pressure plasma jet, Appl. Surf. Sci., 256, 2009, pp. 1496-1501.

[5] Godzimirski J.: Wytrzymałość doraźna konstrukcyjnych połączeń klejowych, WNT, Warszawa, 2002.

[6] Kłonica M., Kuczmaszewski J.: Badania porównawcze wytrzymałości na ścinanie klejowych połączeń zakładkowych stali $316 \mathrm{~L}$ po „szokach termicznych", Przetwórstwo Tworzyw Sztucznych, 2 (164) 2015, s. 125-130.

[7] Mandolfino C., Lertora E., Gambaro C.: Influence of cold plasma treatment parameters on the mechanical properties of polyamide homogeneous bonded joints, Surface \& Coatings Technology, 313, 2017, pp. 222-229.
[8] Mirski Z., Wróblewski R., Gołembiewski A.: Odporność połączeń klejowych na oddziaływanie wysokiej temperatury, Przegląd Spawalnictwa, nr $10 / 87,2015$, s. 108-114.

[9] Rudawska A., Danczak I., Müller M., Valasek P.: The effect of sandblasting on Surface properties for adhesion, Intern. Journal of Adhesion \& Adhesives, 70, 2016, pp. 176-190.

[10] Stryczewska H.D.: Technologie zimnej plazmy. Wytwarzanie, modelowanie, zastosowania, Elektryka, Zeszyt 1, 2011, s. 41-61.

[11] Vendemiatti C., Hosokawa R.S., Rangel R.C.C., Bortoleto J.R.R., Cruz N.C., Rangel E.C.: Wettability and surface microstructure of polyamide 6 coated with SiOXCYHZ films, Surf. Coat. Technol., 275, 2015, pp. 32-40.

[12] Zhu L., Teng W., Xu H., Liu Y., Jiang Q., Wang C., Qiu Y.: Effect of absorbedmoisture on the atmospheric plasma etching of polyamide fibers, Surf. Coat. Technol., 202, 2008, pp.1966-1974.

[13] Żenkiewicz M.: Adhezja i modyfikowanie warstwy wierzchniej tworzyw wielkocząsteczkowych, WNT, Warszawa 2000

[14] Karta technologiczna produktu Agomet F330.

[15] Dokumentacja goniometru firmy Krüss, Hamburg, 2009. 


\title{
Superkondensatorowa elektropulsacyjna metoda zwiększenia odporności zmęczeniowej wyrobów wykonanych z blachy austenitycznej
}

\author{
Supercapacitors electropulsing method for improvement \\ the fatigue resistance of the austenitic steel sheets
}

\section{Streszczenie}

Celem prowadzonych badań było zbadanie wpływu zastosowania pulsacyjnego przepływu prądu o dużej gęstości (z wykorzystaniem zasilacza superkondensatorowego) na żywotność zmęczeniową badanych próbek. W tym celu przeprowadzono analizy eksperymentalne dla grupy próbek niepoddanych pulsacji prądowej i po ekspozycji prądowej. W pracy przedstawiono wyniki badań dla stali austenitycznej AISI 304 (0,04\% C, 1,2\% Mn, 18,16\% Cr, 8\% Ni, 0,335\% Mo, $0,041 \% \mathrm{Si}$ ) w zakresie ograniczonej wytrzymałości zmęczeniowej. Eksperymenty prowadzono na próbkach płaskich z karbem (SENT - Single Edge Notched Tension Specimen) U-kształtnym wykonanym metodą elektroiskrowego drążenia $\left(\mathrm{W}=15 \mathrm{~mm}, \mathrm{t}=0,5 \mathrm{~mm}, \mathrm{a}_{0}=2,5 \mathrm{~mm}\right)$. Zastosowano impulsy prądowe dodatnie o różnych czasach trwania oraz częstotliwościach. Badania przeprowadzono na pulsatorze hydraulicznym MTS 810, sterowano stałą amplitudą siły $F_{\max }=1100 \mathrm{~N}$. Uzyskane, wstępne wyniki zachęcają do dalszych analiz i studiów nad szeregiem czynników pozwalających wykorzystać zjawisko elektropulsacji wysokoprądowej w kontekście zwiększania trwałości zmęczeniowej narzędzi lub wyrobów otrzymywanych obróbką plastyczną.

Słowa kluczowe: odporność zmęczeniowa; wykres Wöhlera; metoda obróbki elektropulsacyjnej; stal austenityczna AISI 304

\begin{abstract}
The purpose of the study was to investigate the effect of the use of high density pulsed current (using supercapacitor) on the fatigue life of the tested specimens. For this purpose, experimental analyses were carried out for a two group of samples: without current pulsation and after current exposure. The results of the study for AISI 304 steel (0.04\% C, $1.2 \% \mathrm{Mn}, 18.16 \% \mathrm{Cr}, 8 \% \mathrm{Ni}, 0.335 \% \mathrm{Mo}, 0.041 \% \mathrm{Si})$ for fatigue strength were presented. The experiments were performed on single edge notched tensile specimen (SENT) with U-shaped electro-drilling $(W=15 \mathrm{~mm}, t=0.5 \mathrm{~mm}$, $\mathrm{a}_{0}=2.5 \mathrm{~mm}$ ). Positive current pulses with different durations and frequencies were used. The tests were carried out on a hydraulic pulsator MTS 810 , controlled by a constant force amplitude $F_{\max }=1100 \mathrm{~N}$. Obtained initial results encourage for further analyzes and studies with a number of factors that allow the use of high current electricity in the context of increasing the fatigue life of tools or products obtained by plastic metal forming.
\end{abstract}

Keywords: fatigue resistance; Wöhler diagram; electropulsing metod; AISI 304 steel

\section{Wstęp}

Zagadnienie wpływu zewnętrznego pola magnetycznego i elektrycznego na odpowiedź mechaniczną materiału określana jest mianem efektu pól krzyżowych.

Do najbardziej znanych i rozwijanych zagadnień tego typu należy zaliczyć m.in. efekt magnetomechaniczny w postaci wykorzystania zjawiska odwrotnej magnetostrykcji [1]. Takie wykorzystanie pola magnetycznego i mechanicznej odpowiedzi materiału pozwala na uzyskanie szeregu interesujących zastosowań tego zagadnienia w praktyce inżynierskiej - np. w postaci kamery magnetowizyjnej $[2,3]$.
Relatywnie mało poznanym zjawiskiem krzyżowym jest efekt wpływu zewnętrznego pola elektrycznego na właściwości mechaniczne badanego materiału. Zjawisko to nosi nazwę zjawiska elektroplastyczności i już w roku 1954 Cortan i Baret [4] obserwowali wpływ pola elektrycznego na granice ziaren materiału metalicznego. Inna grupa autorów prac $[5,6]$ dokumentowała wpływ tego zjawiska na ciągliwość materiału i jego zdolność do deformacji. Na tym tle ocena wpływu tego zjawiska na właściwości zmęczeniowe wydaje się być interesująca. Interesującym wykorzystaniem tego zjawiska

Dr hab. inż. Zbigniew Zimniak, prof. PWr; dr inż. Grzegorz Lesiuk; dr inż. Wojciech Wiśniewski - Politechnika Wrocławska.

Autor korespondencyjny/Corresponding author. zbigniew.zimniak@pwr.edu.pl 


\begin{tabular}{|c|c|c|c|c|c|c|c|c|c|c|c|c|c|}
\hline \multicolumn{10}{|c|}{ Skład chemiczny w [\%] } \\
\hline $\mathbf{C}$ & $\mathbf{M n}$ & $\mathbf{S i}$ & $\mathbf{P}$ & $\mathbf{S}$ & $\mathbf{C r}$ & $\mathbf{N i}$ & $\mathbf{M o}$ & $\mathbf{V}$ & $\mathbf{C u}$ & $\mathbf{A l}$ & $\mathbf{T i}$ & $\mathbf{W}$ & $\mathbf{N}$ \\
\hline 0,0403 & 1,1000 & 0,4100 & 0,0437 & 0,0044 & 18,1600 & 7,9800 & 0,3350 & 0,0938 & 0,3290 & 0,0023 & 0,0089 & 0,0437 & 0,1360 \\
\hline
\end{tabular}

jest możliwość „leczenia pęknięć” w stalowych elementach konstrukcyjnych [7]. Jednak niewiele miejsca poświęca się w literaturze na wykorzystanie tego zjawiska w badaniach zmęczeniowych, dlatego też niniejsza praca przedstawia wstępne wyniki badań autorów w tym zakresie. W kontekście technologicznym wyroby otrzymywane za pomocą różnych metod obróbki plastycznej oraz stosowane w tych procesach narzędzia podlegają bardzo często działaniu obciążeń zmęczeniowych. Zwiększenie trwałości zmęczeniowej staje się kluczowym zagadnieniem np. w przemyśle lotniczym, czy też eksploatacji narzędzi kuźniczych.

\section{Materiał i metoda}

Obiektem badań były próbki płaskie z karbem ze stali austenitycznej AISI 304 przedstawione na rysunku 1 o składzie chemicznym zamieszczonym w tablicy I.

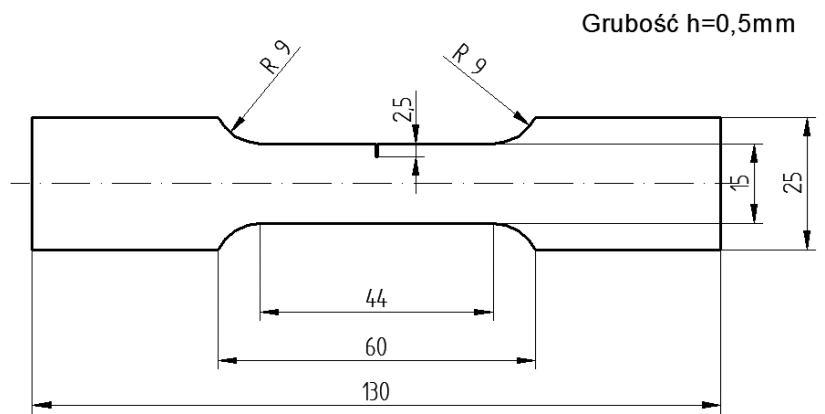

Rys. 1. Rysunek wykonawczy próbek płaskich używanych podczas eksperymentu

Fig. 1. Working drawing of flat samples used during the experiment

Do badań przygotowano próbki z bocznym koncentratorem naprężeń $\left(k_{t}=5,88\right)$ obliczonym zgodnie z pracą [8]. Badania wytrzymałościowe przeprowadzono na pulsatorze hydraulicznym MTS 810 . Maszyną sterowano ze stałą amplitudą siły $F_{\max }=1100 \mathrm{~N}$. Widmo obciążenia miało charakter sinusoidalny o współczynniku asymetrii cyklu $R=0,1$. Podczas badań rejestrowano amplitudy sygnału siły i odpowiadające jej amplitudy odkształcenia oraz liczbę cykli. W badaniach zastosowano specjalnie opracowany generator impulsów wysokoprądowych działający z zastosowaniem superkondensatorów.

Superkondensatory działają na zasadzie wykorzystania zjawiska podwójnej warstwy Helmholtza, która stanowi obszar na granicy dwóch faz odznaczający się statystycznie nierównomiernym rozmieszczeniem elektronów lub jonów w obu fazach. Wielkie pojemności uzyskiwane są wykorzystując bardzo dużą powierzchnię styku materiału elektrod węglowych (pojemności są ok. 10000 razy większe niż tradycyjnych kondensatorów). Największymi zaletami superkondensatorów są: wysoka moc impulsowa, wysoka gęstość energii, czas życia, wysoka sprawność (od 84 do 95\%). Zaletą superkondensatorów jest też liczba cykli pracy, która może wynosić nawet ponad milion.

Najważniejsze parametry generatora prądowego to: maksymalne napięcie pracy $2,7 \mathrm{~V}$, pojemność banku kondensatorów $14000 \mathrm{~F}$, impedancja pojedynczego kondensatora $<200 \mu \Omega$, maksymalna wartość prądu impulsowego $15 \mathrm{kA}$. Zastosowano całkowicie elektroniczne przełączanie kondensatorów z użyciem tranzystorów MOSFET. Generator prądowy do realizacji procesów elektropulsacji pokazano na rysunku 2. Rysunek 3 przedstawia realizację sposobu doprowadzenia prądu do próbki.

Prąd do próbki dostarczano za pomocą miedzianych przewodów oraz zacisków śrubowych. Zastosowano impulsy prądowe prostokątne dodatnie o parametrach: czas trwania impulsu $t_{i}$ oraz okres $t_{0}$ (rys. 4). Parametry prądowe dla poszczególnych próbek dla całkowitego czasu próby $7 \mathrm{~s}$ i okresu równego $1 \mathrm{~ms}$ : próbka $1-\mathrm{t}_{\mathrm{i}}=200 \mu \mathrm{s}$, próbka $2-\mathrm{t}_{\mathrm{i}}=50 \mu \mathrm{s}$. $\mathrm{W}$ ten sposób przygotowano do badań dwie grupy próbek: bez ekspozycji prądowej i po ekspozycji prądowej - zrealizowanej po określonej liczbie cykli odpowiadającej fazie nukleacyjnej sub-mikro pęknięć.

\section{Wyniki badań i dyskusja}

W początkowej fazie badań przeprowadzono statyczną próbę rozciągania próbki płaskiej z karbem przedstawionej na rysunku 1. Eksperyment sterowano stałą prędkością

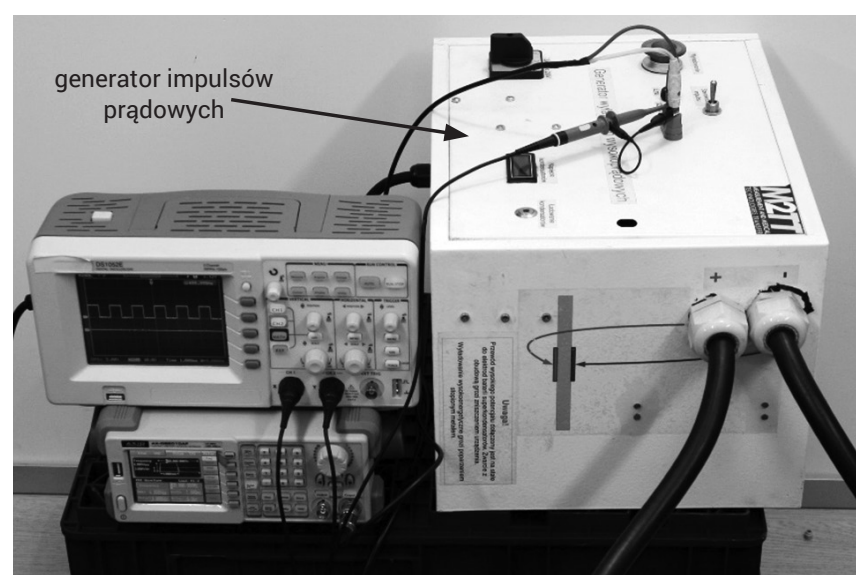

Rys. 2. Superkondensatorowy generator prądowy

Fig. 2. Supercondenser current generator

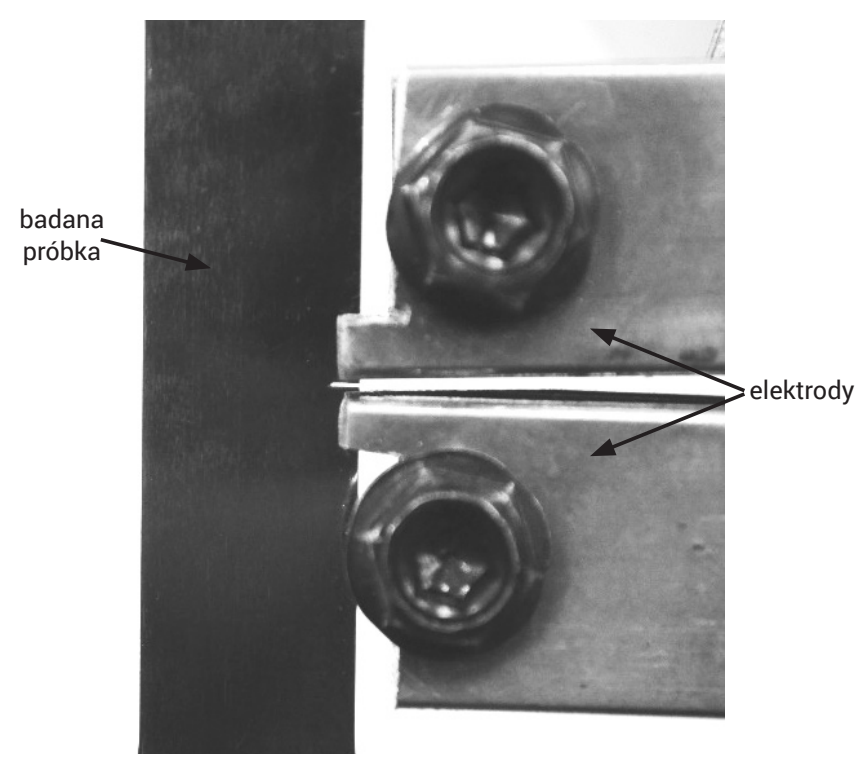

Rys. 3. Próbka wraz z elektrodami doprowadzającymi prąd Fig. 3. Sample with electrodes that supply current 


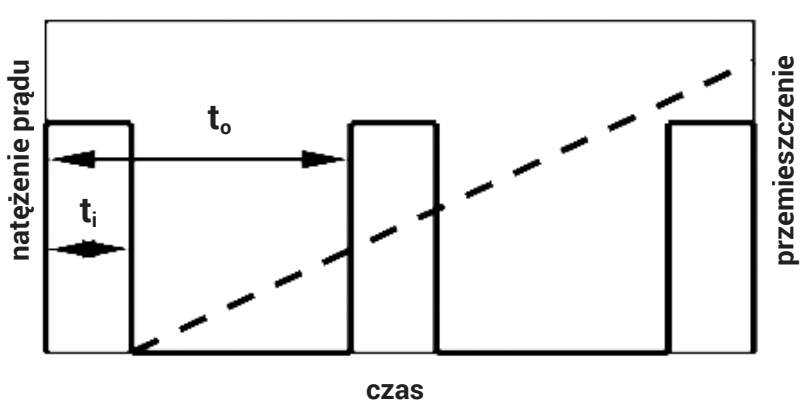

Rys. 4. Parametry prądu impulsowego

Fig. 4. Impulse current parameters

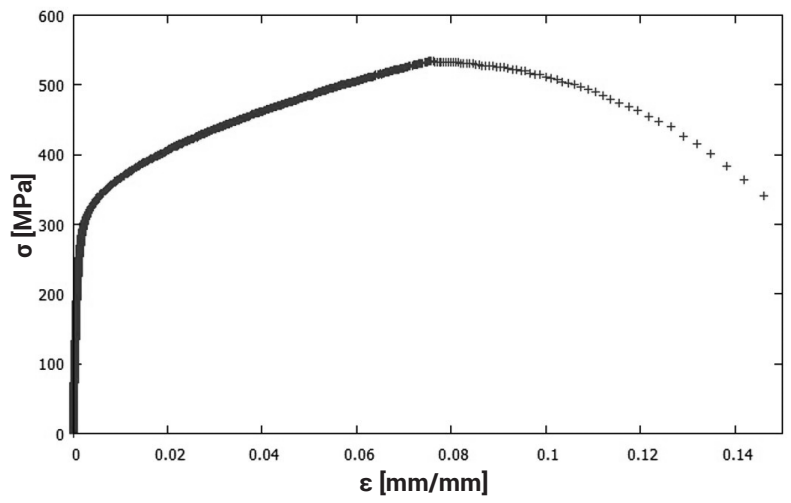

Rys. 5. Statyczna próba rozciągania próbki z karbem $k_{t}=5,88$, stal AISI 304

Fig. 5. Static sample tensile test with notch $\mathrm{k}_{\mathrm{t}}=5.88$, stal AISI 304

Tablica II. Żywotność próbek Table II. The viability of the samples

\begin{tabular}{|c|c|c|c|}
\hline $\begin{array}{c}\text { Próbka 1 } \\
\text { bez prądu }\end{array}$ & $\begin{array}{c}\text { Próbka 2 } \\
\text { bez prądu }\end{array}$ & $\begin{array}{c}\text { Próbka 3 } \\
\text { z prądem }\end{array}$ & $\begin{array}{c}\text { Próbka 4 } \\
\text { z prądem }\end{array}$ \\
\hline$N_{f}=145912$ & $N_{f}=156362$ & $N_{f}=173268$ & $N_{f}=174777$ \\
\hline
\end{tabular}

przyrostu siły, $60 \mathrm{~N} / \mathrm{s}$ co odpowiadało przyrostowi naprężenia $10 \mathrm{MPa} / \mathrm{s}$. Dzięki próbie statycznej (rys. 5) wstępnie ustalono progowe wartości sił, którymi należało obciążać próbkę podczas badań cyklicznych.

Na rysunku zestawiono wyniki pomiarowe z badań zmęczeniowych stali AISI 304 w skali podwójnie logarytmicznej. Po wyznaczeniu krzywej Wöhlera (rys. 6) wybrano jeden poziom, dla którego siła wynosiła $F_{\max }=1100 \mathrm{~N}$ i na tym poziomie przebadano jeszcze dwie próbki z przerwą w badaniu, w której próbki były poddawane działaniu prądu, po czym badania kontynuowano aż do zniszczenia. W sumie dla progu $1100 \mathrm{~N}$ przebadano cztery próbki, nr 1 i 2 obciążano do zniszczenia, a próbki nr 3, 4, z przerwą na ekspozycję prądową.

W tablicy II zestawiono liczbę cykli do zniszczenia dla każdej z próbek.

$\mathrm{Na}$ podstawie danych uzyskanych z eksperymentu powyższej tabeli można ocenić, że żywotność próbek po ekspozycji prądowej wzrosła (próbki 3 i 4).

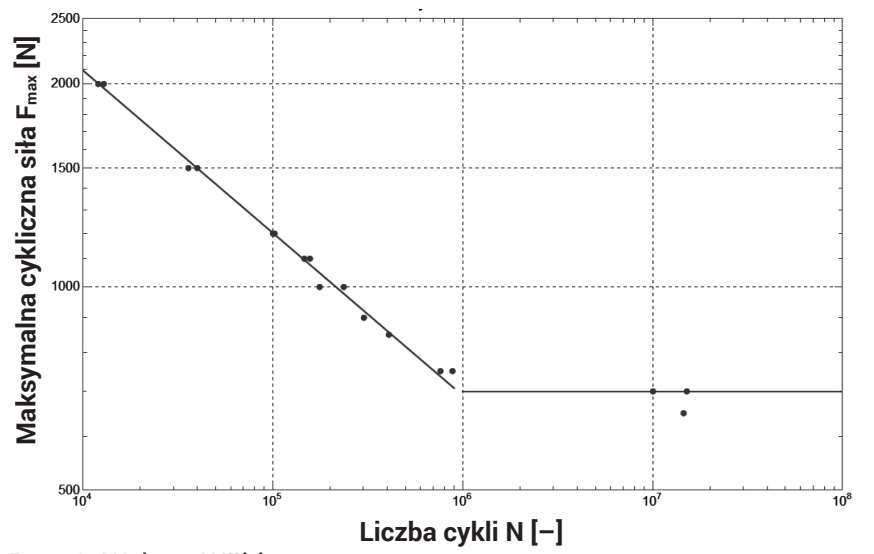

Rys. 6. Wykres Wöhlera

Fig. 6. Wöhler diagram

\section{Podsumowanie i wnioski}

W pracy zaprezentowano wstępne wyniki badań zmęczeniowych wybranych próbek poddanych ekspozycji prądowej celem uzyskania informacji o możliwościach zwiększania żywotności zmęczeniowej wywołanej stymulacją prądową. Stymulacja prądowa miała na celu inicjację zjawiska elektroplastyczności. W licznych pracach udokumentowano pozytywny wpływ tego

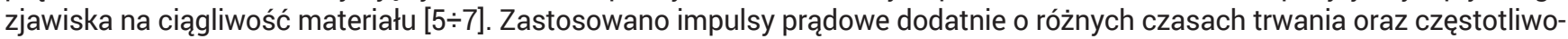
ściach. Badania przeprowadzono na pulsatorze hydraulicznym MTS 810, sterowano stałą amplitudą siły $F_{\max }=1100 \mathrm{~N}(R=0,1)$. Rejestrowana liczba cykli do zniszczenia w grupie próbek po ekspozycji prądowej była większa niż w przypadku próbek niepoddanych ekspozycji prądowej (przeciętnie o ok. 11\%).

Zakres dalszych prac badawczych koncentruje się na ocenie zmian temperatury i jej wpływu na mikrostrukturę materiału w trakcie ekspozycji prądowej. Kolejnym istotnym elementem będzie próba (statystycznie ważna) oceny wpływu ekspozycji prądowej na żywotność próbek w zróżnicowanych warunkach obciążeniowych.

Uzyskane, wstępne wyniki zachęcają do dalszych analiz i studiów nad szeregiem czynników pozwalających wykorzystać zjawisko elektropulsacji wysokoprądowej w kontekście zwiększania trwałości zmęczeniowej narzędzi lub wyrobów otrzymywanych obróbką plastyczną. Perspektywy aplikacyjne tego zjawiska wiążą się także z możliwością "leczenia pęknięć" w cienkościennych konstrukcjach metalowych - wymaga to jednak ugruntowanych badań o charakterze poznawczym.

Prace eksperymentalne zostały współfinansowane ze środków własnych Katedry Mechaniki i Inżynierii Materiałowej w ramach realizowanych badań podstawowych i aplikacyjnych zaawansowanych technologicznie rozwiązań z zakresu inżynierii materiałowej i mechaniki

\section{Literatura}

[1] Zimniak Z., Hankiewicz S.: Badania magnetyczne procesów tłoczenia blach, Obróbka Plastyczna Metali 17, 2006, s. 25-31.

[2] Kaleta J., Lewandowski D., Wiewiórski P.: 3D Magnetovision Scanner as a Tool for Investigation of Magnetomechanical Principles, Solid State Phenomena, Vol. 154, 2009, pp. 181-186.

[3] Kaleta J. Wiewiórski P. Construction of magnetic scanner for application in experimental mechanics, materiały konferencyjne 26th Danubia Adria Symposium on Advances in Experimental Mechanics, 23-26.09.2009, Leoben, Austria.
[4] Cohen M.H., Barrett C.S.: Physical Review B 95, 1954, pp. 1094-1095.

[5] Machlin E.S.: Journal of applied physics 30, 1959, pp. $1109-1110$.

[6] Troitskii O.A, Likhtman V.I.: Akademiya nauk SSSR 148, 1963, pp. 332-334.

[7] Song H., Wang Z.J.: Microcrack healing and local recrystallization in pre-deformed sheet by high density electropulsing, Materials Science and Engineering: A, Volume 490, Issues 1-2, 25 August 2008, Pages 1-6, ISSN 0921-5093, http:// dx.doi.org/10.1016/j.msea.2007.12.037.

[8] Pilkey D.: Stress concentration factors. A Wiley-Interscience Publication, 1997. 


\title{
Wpływ temperatury procesu zgrzewania tarciowego z przemieszaniem - FSW - na wytrzymałość złącza
}

\author{
Influence of temperature of friction stir welding process \\ with mixing - FSW - on the strength of the weld
}

\section{Streszczenie}

Stosowanie podgrzewania prowadzi do niwelacji odkształceń plastycznych zgrzewanych cienkościennych blach metodą FSW. Podgrzewanie to podwyższa temperaturę procesu, umożliwiając stosowanie większych prędkości posuwowych, a co za tym idzie - skraca jego czas. Badania złącza wykonanego przy jednakowych parametrach wykazały znacznie większą wytrzymałość na rozciąganie w przypadku zgrzewania z zastosowaniem podgrzewania. Badania przeprowadzone kamerą termowizyjną ukazały proces rozchodzenia się ciepła. Zauważono, że temperatura w początkowych fazach zgrzewania jest znacznie niższa, co bez wątpienia powoduje powstawanie złącza o niższej wytrzymałości.

Słowa kluczowe: zgrzewanie tarciowe z przemieszaniem; wytrzymałość złącza FSW; połączenie zakładkowe; zgrzewanie aluminium; podgrzewanie podczas FSW

\section{Abstract}

The use of heating leads to reducing plastic deformations of thin sheets welded by the FSW method. Preheating increases the process temperature and allows higher feed rates to be used, thus reducing the time of the process. Tests made on connections with the same parameters showed much higher tensile strength in the case of using heating. Thermal imaging studies have shown the heat dissipation process and it has been noticed that the initial temperature is significantly lower, which undoubtedly results in the formation of a lower strength weld.

Keywords: Friction Stir Welding; FSW connection strength; overlapping connection; aluminum welding; FSW with heating

\begin{abstract}
Wstęp
Metoda zgrzewania tarciowego z przemieszaniem (ang. Friction Stir Welding - FSW) jest obecnie jedną z metod, nad którą prowadzone są liczne badania spajania w stanie stałym. Zastosowanie tej technologii umożliwia łączenie metali uważanych za niespawalne. Do takich metali zalicza się stop aluminium 2024, który w swym składzie posiada $3,80 \div 4,90 \%$ Cu, a co za tym idzie wykazuje wysoką skłonność do powstawania pęknięć podczas procesu spawania. W przemyśle lotniczym stop ten powszechnie stosowany jest po procesie utwardzania wydzieleniowego, co ze względu na wysokie temperatury procesu oraz przemiany, które osłabiłyby znacznie materiał łączony, dyskwalifikuje metode spawania. W postaci blach o grubości $0,6 \div 1 \mathrm{~mm}$ stop 2024 w stanie T351 wykorzystuje się jako materiał na pokrycia samolotów. Proces Friction Stir Welding zachodzi poniżej temperatury topnienia, dlatego też z powodzeniem może być on stosowany do spajania tego typu materiałów. Obecnie do łączenia struktur lotniczych wykorzystuje się dość pracochłonną i kosztowną metodę nitowania. Metoda FSW
\end{abstract}

jest alternatywą do tego typu zadań, która wymaga dokładnego przebadania procesu i zjawisk, jakie zachodzą podczas procesu. Zgrzewanie tarciowe z przemieszaniem struktur cienkościennych niesie ze sobą kilka problemów, do których zalicza się m.in. powstawanie deformacji. Po wstępnej analizie procesu stwierdzono, że jedną z przyczyn powstawania odkształceń blach są duże gradienty temperaturowe. W celu zmniejszenia różnic temperaturowych w materiale łączonym zaprojektowano uchwyt podgrzewający zgrzewane blachy. Jak się spodziewano, zabieg ten zmniejszył odkształcenia zgrzewanych blach, a także wpłynął znacząco na własności wytrzymałościowe złącza.

\section{Charakterystyka procesu FSW}

Proces zgrzewania tarciowego z przemieszaniem polega na wprowadzeniu rotującego narzędzia w materiał zgrzewany i przesuwaniu go wzdłuż linii styku (rys. 1). Podczas procesu

Inż. Krzysztof Ochałek - Państwowa Wyższa Szkoła Zawodowa w Krośnie.

Autor korespondencyjny/Corresponding author. krzysiekochalek14@interia.pl 


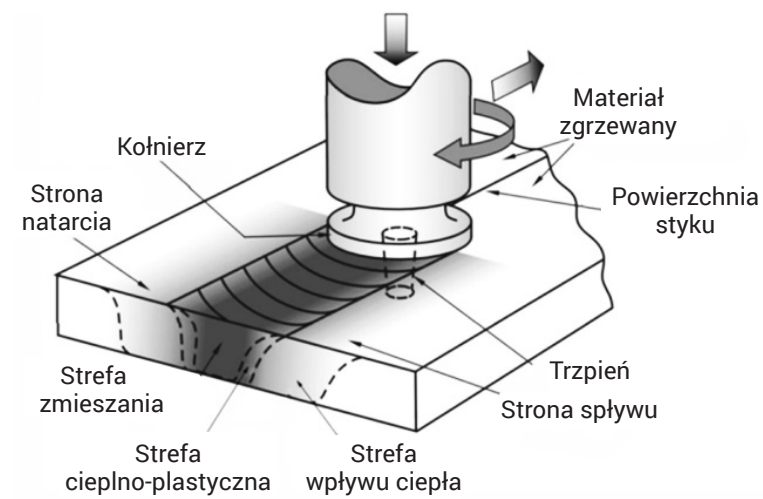

Rys. 1. Schemat procesu FSW [2]

Fig. 1. Scheme of the FSW process [2]

spajania, aby przebiegł on pomyślnie, konieczne jest sztywne zamocowanie i dociśnięcie do siebie łączonych elementów. Specjalne narzędzie, obracając się wskutek tarcia oraz mechanicznego mieszania materiału, wytwarza ciepło, skutkiem czego jest uplastycznienie zgrzewanego materiału, który bez problemu może zostać przemieszany.

Ilość ciepła konieczna do zajścia procesu FSW jest znacznie niższa, aniżeli podczas spawania tradycyjnego. Stosując metodę zgrzewania tarciowego z przemieszaniem możliwe jest uniknięcie tworzenia się niekorzystnych faz osłabiających materiał spajany. Naprężenia termiczne są również znacznie mniejsze, jednakże w obydwu przypadkach nie jest możliwe ich całkowite wyeliminowanie. Mikrostruktura złącza wykonanego metodą FSW jest drobnoziarnista i zasadniczo pozbawiona pęknięć, które występują bardzo często podczas spawania [4,6]. Efektywność połączenia określana jako stosunek wytrzymałości materiału spajanego metodą FSW do wytrzymałości materiału rodzimego, w przypadku próby rozciągania osiąga do 96\% [3].

\section{Ciepło procesu}

Ciepło podczas procesu FSW powstaje wskutek tarcia pomiędzy narzędziem a zgrzewanym materiałem. Podstawą dobrze wykonanej zgrzeiny jest dobór odpowiednich parametrów zgrzewania, które bezpośrednio wpływają na ciepło procesu, a co za tym idzie - na budowę, a także własności wytrzymałościowe złącza. Dla narzędzia o trzpieniu walcowym przedstawionym na rysunku 2 wartość momentu tarcia można wyliczyć z zależności 1 (gdzie: $\mu$ - współczynnik tarcia między narzędziem, a materiałem zgrzewanym). Korzystając ze wzoru 2., znając prędkość obrotową - n i prędkość zgrzewania $-v_{z}$, można wyliczyć energię jednostkową w punkcie [1].

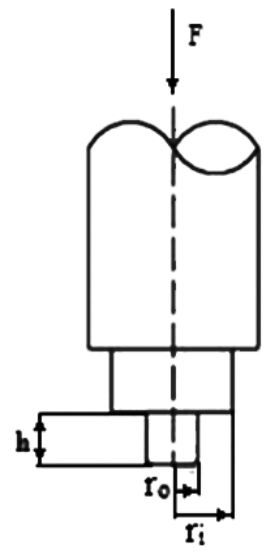

Rys. 2. Schemat narzędzia

Fig. 2. Scheme of the tool

$$
\begin{aligned}
& M_{t}=2 \mu \cdot F\left(\frac{r_{0}}{3}+\frac{r_{i}^{2}}{r_{0}^{2}} \cdot h\right) \\
& E=M_{t} \cdot n / v_{z}
\end{aligned}
$$

Interpretując powyższe wzory można zauważyć, że największy wpływ na ilość generowanego ciepła ma prędkość obrotową oraz prędkość posuwu. Stosując większe prędkości obrotowe zwiększa się ilość generowanego ciepła, zwiększając natomiast posuw wydziela się mniejsza jego ilość. Dobranie nieodpowiedniej prędkości obrotowej i posuwowej skutkować może wystąpieniem lokalnych nadtopień łączonych elementów. Może to doprowadzić do utraty jednorodności złącza, wpłynąć na strukturę złącza oraz skutkować powstaniem wydzieleń osłabiających zgrzane elementy. Przypadek nadtopienia materiału łączonego ma miejsce, gdy zastosuje się zbyt wysokie prędkości obrotowe i niskie prędkości posuwowe (rys. 3).

Podczas zgrzewania, stosując równocześnie duże prędkości obrotowe i posuwowe, może dojść do powstania pustek oraz lokalnych nieciągłości zgrzeiny (rys. 4).

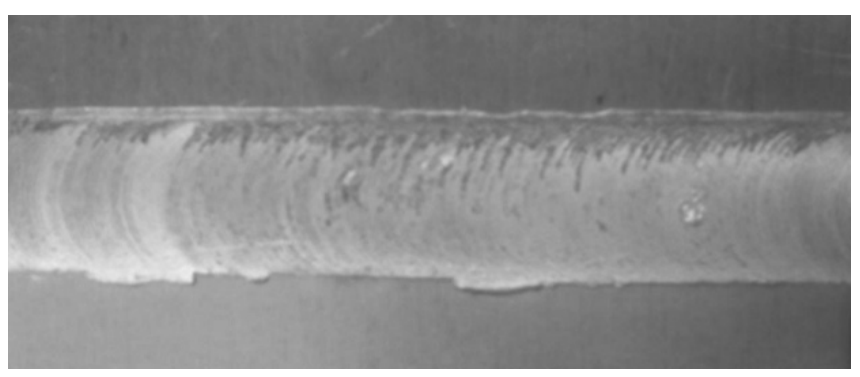

Rys. 3. Nadtopiona powierzchnia zgrzeiny

Fig. 3. Melted weld surface

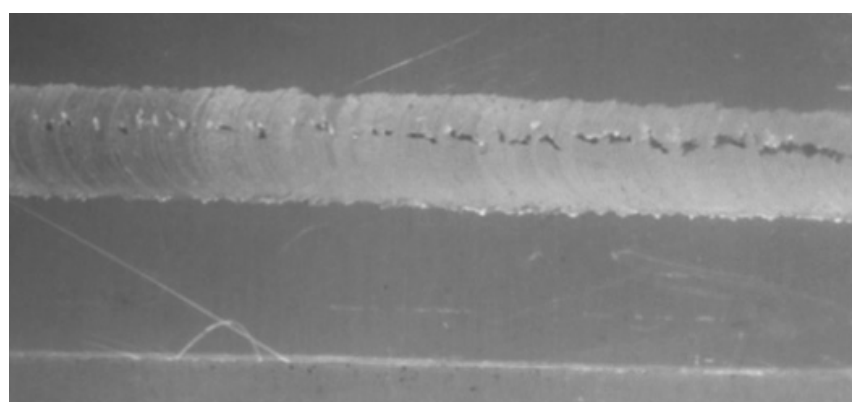

Rys. 4. Nieciągłości liniowe zgrzeiny

Fig. 4. Linear discontinuities of a weld

Na ciepło procesu możemy również wpływać siłą docisku narzędzia do łączonych elementów podczas procesu zgrzewania. Nie można jednak dowolnie manipulować tym parametrem. Stosowanie zbyt małej siły docisku może skutkować powstaniem połączenia adhezyjnego charakteryzującego się znacznie mniejszą wytrzymałością, natomiast zbyt duża siła powstawaniem wklęsłego lica zgrzeiny oraz wypływek [7]. Trzecim, równie niekorzystnym zjawiskiem związanym z siłą docisku jest jej nierównomierność. Przejawia się ona powstaniem zgrzeiny o różnej szerokości (rys. 5).

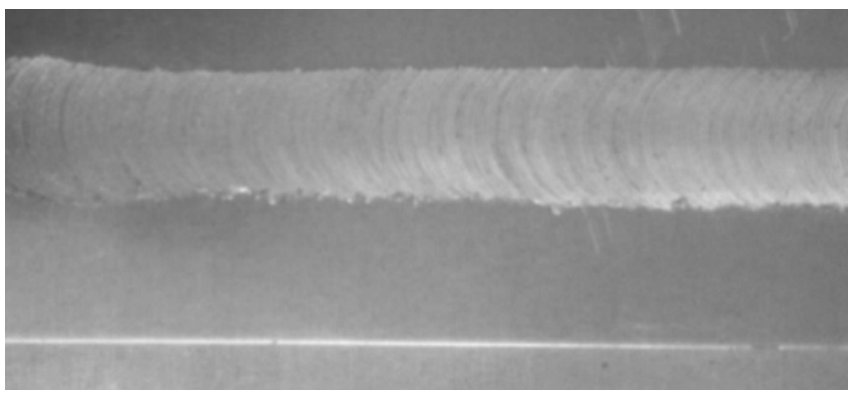

Rys. 5. Nierównomierna szerokość zgrzeiny

Fig. 5. Uneven weld width 


\section{Uchwyt podgrzewający}

W celu aplikacji dodatkowego źródła ciepła zastosowano uchwyt z płytą podgrzewającą elementy zgrzewane oraz instalację sterowaną za pomocą sterownika PLC LOGOV8 [5]. Uchwyt do zgrzewania tarciowego z przemieszaniem materiału zgrzeiny (rys. 6) składa się z kilku zasadniczych elementów, do których należy:

- podstawa,

- płyta grzejna wraz elementami grzejnymi oraz czujnikami temperatury,

- łapy dociskowe,

- ceowniki dociskające zgrzewane blachy.

Zasilanie układu podgrzewającego odbywa się za pośrednictwem transformatora, którego celem jest obniżenie napięcia z sieci trójfazowej (400 V) na 48 V. W płycie grzejnej umieszczono rezystancyjne czujniki temperatury Pt100. Zmiana rezystancji czujników, wynikająca ze zmian temperatury, jest modyfikowana przez przetwornik temperatury CP-03 na sygnał napięciowy o zakresie $0 \div 10 \mathrm{~V}$, informującym o aktualnym stanie temperatury z dokładnością do $5^{\circ} \mathrm{C}$. Tak przetworzone sygnały napięciowe są podłączone do wejść analogowych sterownika PLC Siemens LOGOV8. Sterownik ten jest zaopatrywany w energię elektryczną przy pomocy zasilacza Siemens 230/24 AC (rys. 7). Architektura programu sterownika PLC powstała przy użyciu programu Logo Soft Comfort v8. Zadaniem programu jest sterowanie wyjściami przekaźnikowymi, tak aby przy temperaturze odczytywanej z czujników Pt100 mniejszej niż zadana, załączały się styczniki LC1D12 Schneider. Zwierają one odpowiednie obwody grzejne ze źródłem zasilania. Układ zaprojektowano, tak aby możliwe było płynne sterowanie temperaturą [5].

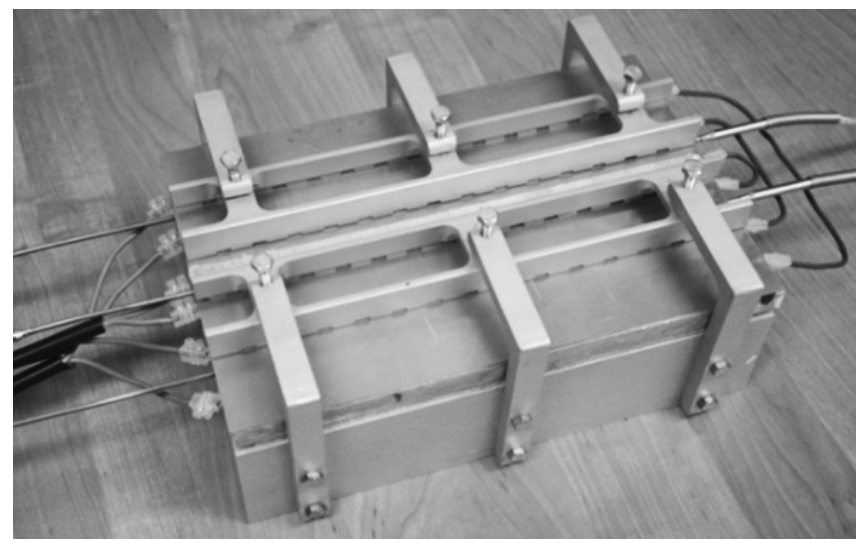

Rys. 6. Uchwyt do zgrzewania metodą FSW z płytą grzejną [5] Fig. 6. FSW welding handle with heating panel [5]

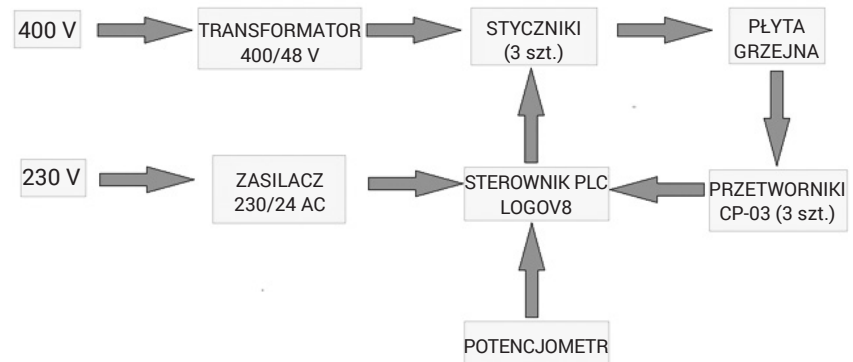

Rys. 7. Schemat blokowy instalacji podgrzewającej Fig. 7. Block diagram of heating installation

\section{Przebieg próby zgrzewania}

Ze względu na stosowanie w lotnictwie połączeń elementów zakładkowych zgrzewaniu poddano blachy grubości 1 mm ze stopu 2024 T351 zgodnie z rysunkiem 8 .

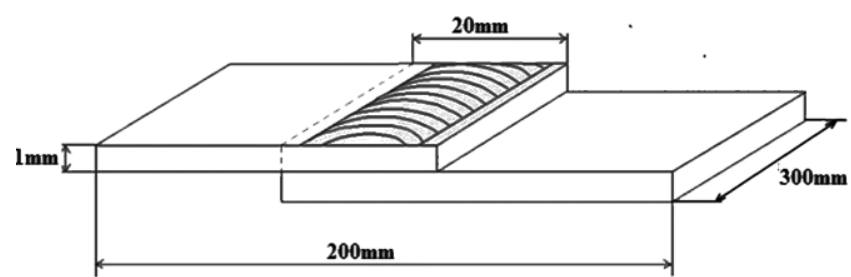

Rys. 8. Schemat wykonywanego złącza

Fig. 8. Scheme of the joint creation

Jako odpowiednie do zgrzewania tego rodzaju blach zastosowano narzędzie Schulter $\mathrm{RH}-10 / 5-\mathrm{S}-\mathrm{O}$ (rys. 9). W celu uniknięcia powstawania wypływek, proces zgrzewania przeprowadzano przy kącie pochylenia narzędzia równemu $2^{\circ}$.

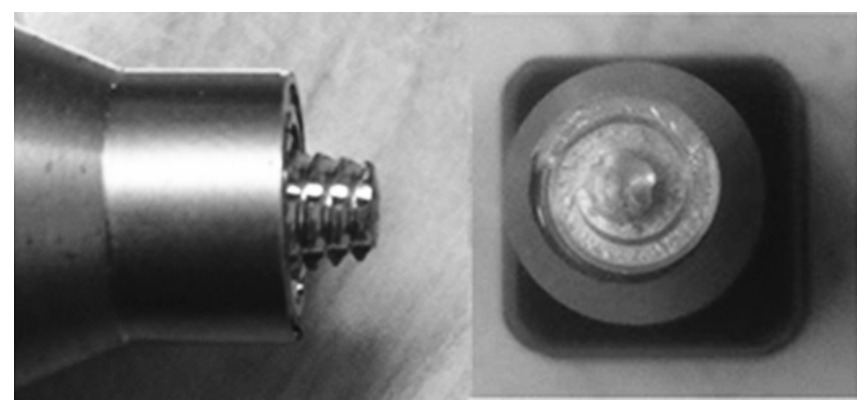

Rys. 9. Narzędzie Schulter RH-10/5-S-O

Fig. 9. Schulter $\mathrm{RH}-10 / 5-\mathrm{S}-\mathrm{O}$ tool

\section{Rozkład temperatury}

Podczas zgrzewania blach bez podgrzewania zarejestrowano proces rozchodzenia się ciepła, co przedstawiono na rysunku 10. Na zdjęciach z kamery termowizyjnej widać, jak powoli nagrzewa się narzędzie. Ma to bez wątpienia wpływ na własności powstałego złącza.

Podczas zgrzewania tarciowego z przemieszaniem temperatura stabilizuje się dopiero po wykonaniu $100 \mathrm{~mm}$ zgrzewu. Temperatura dla parametrów zgrzewania równych S1300 i F300 wynosiła $285^{\circ} \mathrm{C}$ (rys. 11).

Następnie wykonywano próby zgrzewania podgrzewając uchwyt do temperatury równej $160{ }^{\circ} \mathrm{C}$. Efektem tego było uzyskanie wyższej temperatury procesu, która wynosiła $345^{\circ} \mathrm{C}$ (rys. 12).

W początkowej fazie zgrzewania z zastosowaniem podgrzewania zarejestrowano temperaturę równą $291^{\circ} \mathrm{C}$.

\section{Własności wytrzymałościowe}

Z blach w miejscach, w których zanotowano ustabilizowaną temperaturę wycięto próbki szerokości 12,5 mm, a następnie przystąpiono do badań wytrzymałościowych na maszynie Zwick Roell. Na tej podstawie stwierdzono, żenajwyższe własności wytrzymałościowe zgrzanych blach bez podgrzewania uzyskuje się przy prędkości posuwowej równej $300 \mathrm{~mm} / \mathrm{min}$. W tablicy I przedstawiono wyniki wartości siły zrywającej dla różnych prędkości obrotowych.

Tablica I. Własności blach zgrzewanych bez podgrzewania Table I. Properties of welded sheets without preheating

\begin{tabular}{|c|c|c|c|}
\hline & $\begin{array}{c}\text { Prędkość obroto- } \\
\text { wa [obr/min] }\end{array}$ & $\begin{array}{c}\text { Prędkość posu- } \\
\text { wowa [mm/min] }\end{array}$ & $\begin{array}{c}\text { Wartość siły } \\
\text { zrywającej [kN] }\end{array}$ \\
\hline 1 & S800 & F300 & 1,98 \\
\hline 2 & S1300 & F300 & 2,88 \\
\hline 3 & S1500 & F300 & 2,50 \\
\hline
\end{tabular}



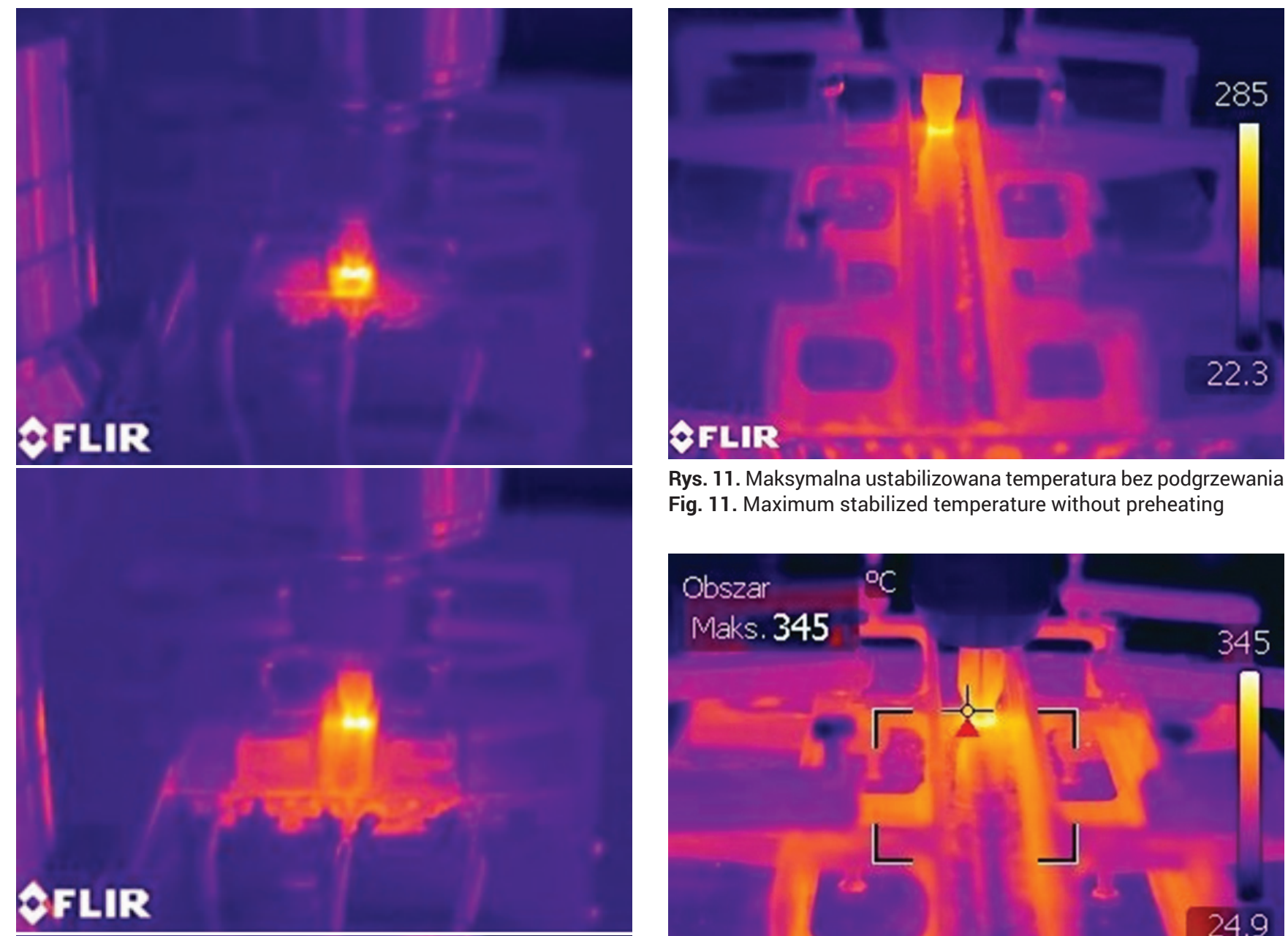

Rys. 11. Maksymalna ustabilizowana temperatura bez podgrzewania Fig. 11. Maximum stabilized temperature without preheating

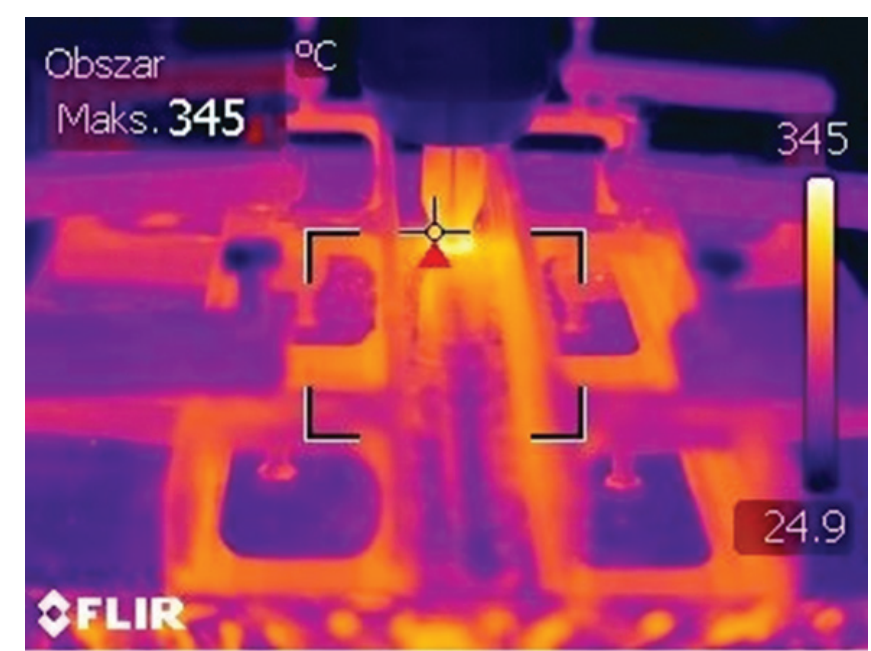

Rys. 12. Ustabilizowana temperatura podczas zgrzewania z podgrzewaniem

Fig. 12. Stabilized temperature during welding with preheating
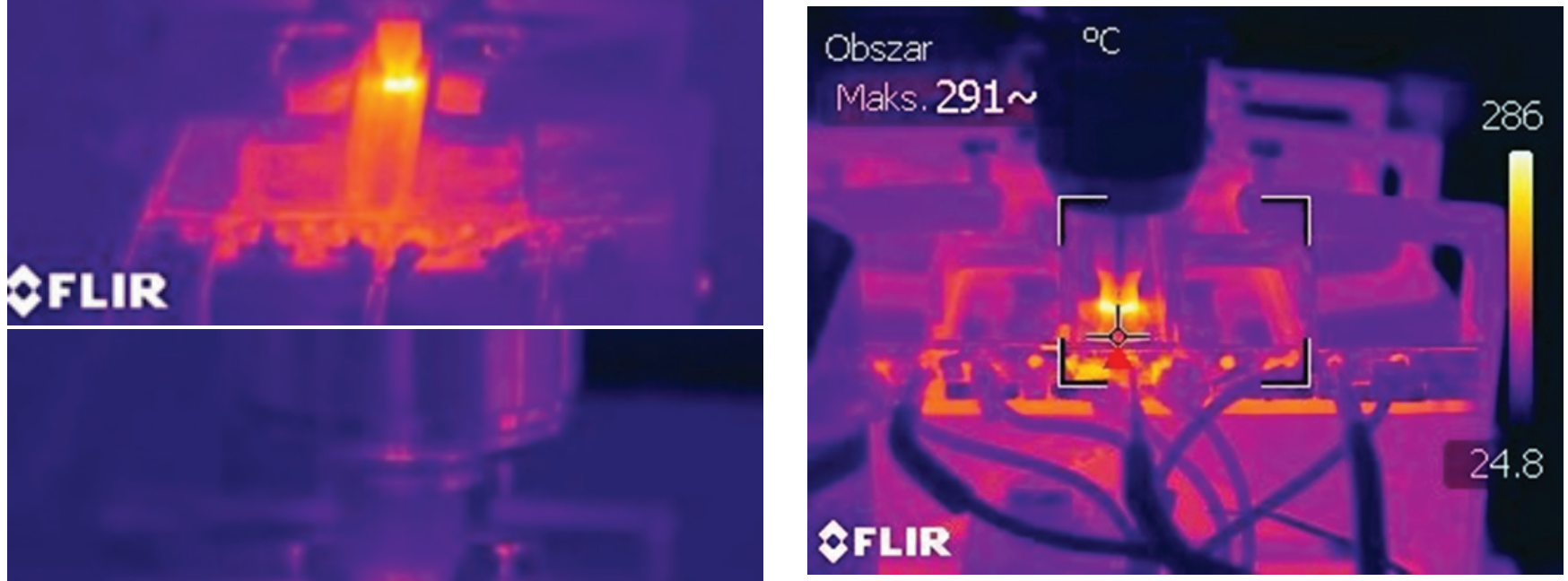

Rys. 13. Temperatura w początkowej fazie zgrzewania z podgrzewaniem

Fig. 13. Temperature in the initial stage of welding with preheating

W celu ukazania wpływu podgrzewania na własności wytrzymałościowe złącza wykonano połączenia podgrzewając uprzednio uchwyt, na którym przeprowadzono proces spajania. Wyniki pomiarów umieszczono w tablicy II.

W celu oceny efektywności połączenia mierzonej jako stosunek wytrzymałości materiału ze zgrzeiną do wytrzymałości materiału rodzimego próbie rozciągania poddano próbkę

Rys. 10. Rozchodzenie się ciepła podczas zgrzewania metodą FSW Fig. 10. Heat propagation during FSW welding 
o przekroju poprzecznym 1 x 12,5 mm. Blacha o takim przekroju przeniosła siłę rozciągającą równą $5,7 \mathrm{kN}$. Zestawienie wykresów próby rozciągania próbek zgrzanych z oraz bez zastosowania podgrzewania, a także litego materiału przedstawiono na rysunku 14.

Tablica II. Własności blach zgrzewanych z zastosowaniem podgrzewania

Table II. Properties of welded sheets with preheating

\begin{tabular}{|c|c|c|c|c|}
\hline & $\begin{array}{c}\text { Prędkość } \\
\text { obrotowa } \\
\text { [obr/min] }\end{array}$ & $\begin{array}{c}\text { Prędkość } \\
\text { posuwowa } \\
{[\mathrm{mm} / \mathrm{min}]}\end{array}$ & $\begin{array}{c}\text { Temperatura } \\
\text { podgrzewa- } \\
\left.\text { nia [ }{ }^{\circ} \mathrm{C}\right]\end{array}$ & $\begin{array}{c}\text { Wartość siły } \\
\text { zrywającej } \\
{[\mathrm{kN}]}\end{array}$ \\
\hline 1 & $\mathrm{~S} 600$ & $\mathrm{~F} 300$ & 160 & 1,64 \\
\hline 2 & $\mathrm{~S} 800$ & $\mathrm{~F} 300$ & 160 & 4,26 \\
\hline 3 & $\mathrm{~S} 1300$ & $\mathrm{~F} 300$ & 160 & 3,68 \\
\hline 4 & $\mathrm{~S} 600$ & $\mathrm{~F} 500$ & 160 & 2,61 \\
\hline 5 & $\mathrm{~S} 800$ & $\mathrm{~F} 500$ & 160 & 3,22 \\
\hline 6 & $\mathrm{~S} 1000$ & $\mathrm{~F} 500$ & 160 & 3,80 \\
\hline 7 & $\mathrm{~S} 1300$ & $\mathrm{~F} 500$ & 160 & 3,61 \\
\hline
\end{tabular}

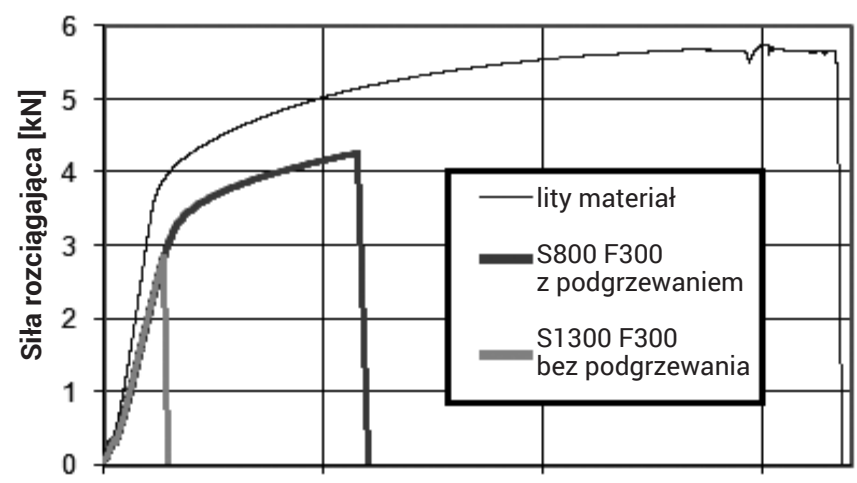

Wydłużenie [mm]

Rys. 14. Wykresy próby rozciągania blach zgrzanych metodą FSW Fig. 14. Graphs of tensile tests of sheets welded with the FSW method

\section{Charakterystyka miejsc zerwania}

Próbki zerwane na maszynie wytrzymałościowej różniły się znacząco pod względem miejsca zerwania. Blachy zgrzane bez podgrzewania zrywały się w strefie cieplno-plastycznej. Zerwaniu ulegała część mająca bezpośredni kontakt z częścią oporową narzędzia (rys. 15). Blachy zgrzane z zastosowaniem podgrzewania niszczyły się, natomiast w strefie zmieszania, w miejscu, gdzie pin mieszał materiał obu blach (rys. 16).

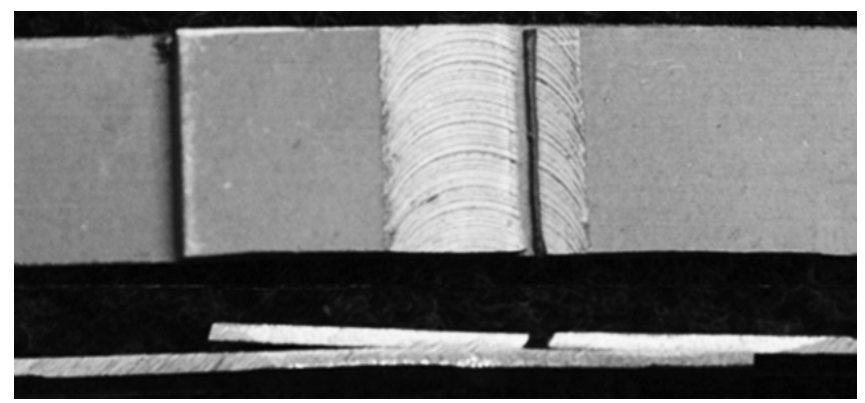

Rys. 15. Widok miejsca zerwania próbki zgrzanej bez zastosowania podgrzewania

Fig. 15. View of the place where the weld was broken without preheating

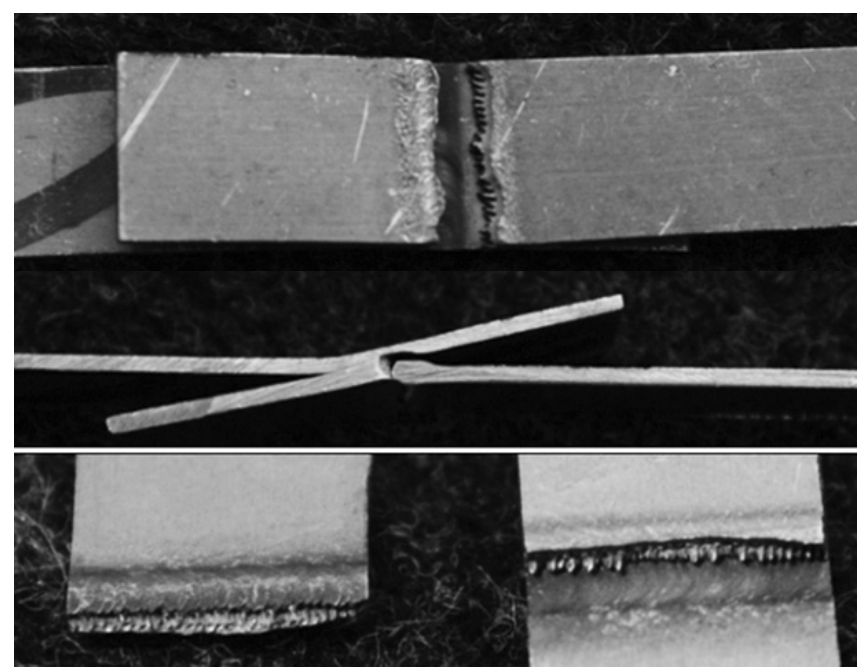

Rys. 16. Widok miejsca zerwania próbki zgrzanej z zastosowaniem podgrzewania

Fig. 16. View of the place where the weld was broken with preheating

\section{Wnioski}

Na podstawie wykonanych badań można stwierdzić, że zastosowanie podgrzewania w procesie zgrzewania cienkich blach, wpływa korzystnie na własności wytrzymałościowe złącza. Temperatura, którą można uzyskać bez podgrzewania jest zbyt niska. Zastosowanie podgrzewania podwyższa tą temperaturę, co przejawia się znacznym wzrostem wytrzymałości złącza. Blachy zgrzane w podwyższonej temperaturze ulegają zniszczeniu w strefie zmieszania. Na zerwanych próbkach widać charakterystyczne ząbki, które obrazują proces mieszania materiału. Blachy, które były poddane zgrzewaniu nie zostały uprzednio oczyszczane z warstwy tlenkowej, co mogło dodatkowo obniżyć wytrzymałość złącza. Wyniki uzyskane podczas zgrzewania z zastosowaniem podgrzewania świadczą o tym, że rozwiązanie takie jest korzystne nie tylko ze względu na mniejsze odkształcenia spajanych elementów, ale również pozwala na zminimalizowanie zużycia narzędzia. Blacha podgrzana wstępnie nie musi być już w tak dużym stopniu nagrzewana przez narzędzie, a co za tym idzie możliwe jest zastosowanie mniejszych prędkości obrotowych. Zwiększanie prędkości posuwowej zmniejsza ilość generowanego ciepła, tak więc podgrzewając zgrzewane elementy możemy przyspieszyć proces spajania. Dodatkowo, zastosowanie podgrzewania prowadzi do polepszenia własności plastycznych materiału. Stosunek wytrzymałości blachy litej (bez zgrzeiny) do blachy zgrzanej zakładkowo z zastosowaniem podgrzewania jest wysoki i sięga $75 \%$. Uzyskanie takiego wyniku pozwala uznać, że złącze zostało wykonane poprawnie. Próbki zgrzane bez podgrzewania do momentu zerwania wydłużyły się tylko o 1,4 mm, natomiast z zastosowaniem podgrzewania aż o 5,8 mm, co widać na wykresach próby rozciągania. Ogólny przebieg tych wykresów jest bardzo podobny do wykresu rozciągania blachy litej (niepoddanej procesowi spajania). Świadczy to o tym, że ciepło wydzielone podczas procesu zgrzewania z zastosowaniem podgrzewania wpłynęło pozytywnie na złącze. 


\section{Literatura}

[1] Dymek S.,Kalemba I., i Blicharski M.: Friction stir welding of aluminium 7136-T76511; Science and Technology of Welding and Joining; 2008.

[2] Kalemba I.: Mikrostruktura i własności połączeń stopów aluminium wykonanych metodą zgrzewania tarciowego z mieszaniem materiału zgrzeiny; rozprawa doktorska; Kraków 2010.

[3] Kocańda D., Góra A.: Nowe technologie łączenia tarciowego metali; Biuletyn WAT; 2010, Tom LIX, 2.

[4] Lityńska L., Braun R., Staniek G., Dalle Donne C., Dutkiewicz J.: TEM study of the microstructure evolution in a friction stir-welded AlCuMgAg alloy; Materials Chemistry and Physics, 81, 2003.
[5] Ochałek K.: Zgrzewanie tarciowe z przemieszaniem blach cienkościennych; Przegląd Mechaniczny, 1/ 2017.

[6] Pietras A., Zadroga L.: Rozwój metody zgrzewania tarciowego z mieszaniem materiału zgrzeiny (FSW) i możliwości jej zastosowania; Biuletyn Instytutu Spawalnictwa, 5, 2003.

[7] Pietras A., Zadroga L., Łomozik M.: Charakterystyka zgrzeiny utworzonej metodą zgrzewania z mieszaniem materiału zgrzeiny (FSW); Biuletyn Instytutu Spawalnictwa, 47, 2003. 


\title{
Nitowanie bezotworowe blach miedzianych - wybrane aspekty
}

\author{
Selected aspects of SPR copper sheets joining
}

\section{Streszczenie}

Metoda bezotworowego nitowania blach swój rozwój zawdzięcza głównie zmieniającym się wymaganiom w przemyśle motoryzacyjnym ze względu na zastosowanie nowych materiałów, zwłaszcza na elementy karoserii, i konieczności ich efektywnego łączenia. Obserwowane tendencje do stosowania w konstrukcjach elementów lekkich, a przy tym wytrzymałych, wykonanych ze stopów aluminium, kompozytów, tworzyw sztucznych itd., są tego przykładem. W referacie zaprezentowano wybrane aspekty prób zastosowania procesu nitowania bezotworowego do łączenia blach miedzianych. Zastosowano opracowaną wcześniej procedurę modelowania numerycznego procesu tworzenia połączenia i jego obciążania. Analizy numeryczne zostały zweryfikowane eksperymentalnie przy wykorzystaniu przemysłowego stanowiska badawczego wykorzystującego specjalny przyrząd wyposażony w zaprojektowany tor pomiarowy. Do symulacji wykorzystano komercyjne oprogramowanie ogólnego przeznaczenia MSC.Marc, służące m.in. do modelowania zjawisk o charakterze nieliniowym. Zaprezentowane wyniki mają charakter jakościowy i stanowią początek działań podejmowanych w ramach współpracy z firmą produkcyjną, mającej na celu optymalizację oraz opracowanie wewnętrznych wytycznych do projektowania połączeń blach miedzianych.

Słowa kluczowe: nitowanie bezotworowe; łacznie miechaniczne; modelowanie numeryczne

\begin{abstract}
The self-piercing riveting - SPR - for sheet metal joining owes its development mainly to the changing requirements of the automotive industry due to the use of new materials, especially for the body parts, and the need for their efficient joining. The observed trends to use for the structural components lightweight, yet durable, aluminum alloys, composites, plastics, etc., are examples of this tendency. The paper presents selected aspects of the attempts to use the SPR method for joining copper sheets. A numerical modeling of the process of joint formation and its loading was introduced. These analysis were verified experimentally using an industrial set-up consisting of a mobile unit for riveting equipped with a specially designed components for a measuring track settting. Simulation were carried out with commercial software based on the finite element method MSC.Marc, dedicated for the nonlinear analysis. The presented results are of a qualitative nature and are the beginning of activities undertaken in cooperation with the production company, aimed at optimizing and developing internal guidelines for the design of copper sheet joints.
\end{abstract}

Keywords: self-piercing riveting; mechanical joining; numerical modeling

\section{Wstęp}

Nitowanie bezotworowe (ang. self-piercing riveting - SPR) jest techniką łączenia pod naciskiem wykorzystującą nit o specjalnym, rurowym kształcie, zwykle wykonany ze stali niskostopowej, do łączenia dwóch lub więcej arkuszy blach. Klasyfikowana jest w obszarze obróbki plastycznej ze względu na charakter odkształcenia materiałów łączonych jak i elementu łączącego, czyli nitu. W czasie procesu łączenia dochodzi do przebicia górnej blachy (blach) i zagłębienia nitu wraz z jego odkształceniem w blasze dolnej, schemat na rysunku 1. W tak prawidłowo wykonanym połączeniu, przy zapewnieniu ciągłość dolnej blachy, utrzymana zostaje szczelność i odpowiednia wytrzymałość. Siła wymagana do utworzenia tego typu połączenia zależy przede wszystkim od rodzaju materiałów i ich grubości. W przypadku blach z metali nieżelaznych wartości osiąganych sił dochodzą do $50 \mathrm{kN}$, natomiast dla łączonych blach stalowych mogą być wyższe i osiągać w pewnych przypadkach 100 kN. Nitowanie techniką SPR jest stosowane przede wszystkim w przemyśle motoryzacyjnym, np. przy łączeniu elementów karoserii i części nadwozia. Ostatnimi czasy rozszerzył się zakres zastosowań tej metody, głównie ze względu na rozwój oprzyrządowania oraz popularyzację metody. Można znaleźć przykłady zastosowań w montażu różnego rodzaju instalacji, np. kanałów wentylacyjnych czy w elementach

Dr inż. Robert Cacko, dr inż. Jacek Goliński, dr inż. Piotr Czyżewski - Politechnika Warszawska.

Autor korespondencyjny/Corresponding author. r.cacko@wip.pw.edu.pl 

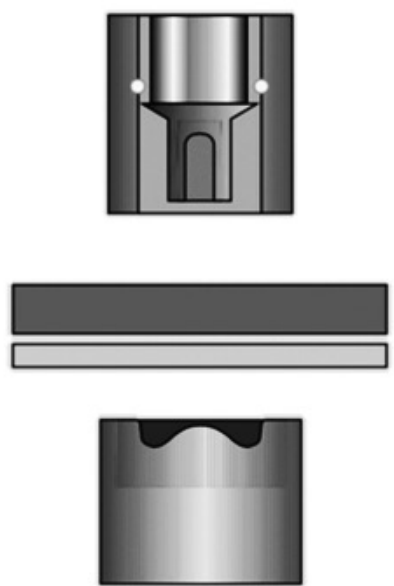

Rys. 1. Schemat procesu łączenia - główne etapy [2]

Fig. 1. Self-piercing riveting outline [2]

nośnych wykonanych z blach lub profili otwartych o niewielkiej grubości, takich jak wszelkiego rodzaju obudowy, stelaże, kratownice itp. W ostatnich latach opracowano wiele artykułów dotyczących zarówno opisu czynników wpływają-

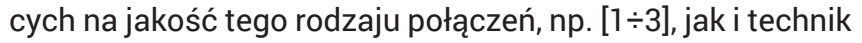

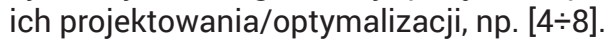

\section{Stanowisko badawcze}

W próbach eksperymentalnych wykorzystano specjalny przyrząd mobilny do nitowania o napędzie elektro-hydraulicznym ESN50BH, stanowiący część zestawu RIVSET ${ }^{\circledR}$ HTF 50 kN firmy Böllhoff, w którym elektryczny silnik zasila hydrauliczny tłok o maksymalnej sile nacisku stempla $50 \mathrm{kN}$, rysunek 2a. Poza standardowym wyposażeniem zestaw jest uzupełniony o niestandardową C-ramę SNK50CBH, umożliwiającą nitowanie w większej odległości od krawędzi blach - maksymalnie ok. $120 \mathrm{~mm}$. Wybrane dane dotyczące urządzenia zestawiono poniżej:

- masa: ok. 7,7 kg (z akumulatorem),

- siła nacisku: do $50 \mathrm{kN}$,

- napięcie: $12 \mathrm{VDC}$

- czas nitowania: $3 \div 5 \mathrm{~s}$,

- wydajność: ok. 300 nitowań/jedno ładowanie akumulatora.

W celu dokonania pomiaru sił oraz przemieszczeń stempla w procesie łączenia konieczne było uzbrojenie urządzenia w dodatkowe elementy pomiarowe oraz zmodyfikowanie mocowania matrycy. W tym celu zaprojektowano mocowanie czujników siły, przemieszczenia uwzględniając zakres przestrzeni roboczej i zakresu przemieszczeń stempla. W celu montażu czujnika siły zostały wykonane dwa specjalnie zaprojektowane elementy pośrednie: sworzeń umieszczony w gnieździe matrycy C-ramy z gwintem w celu osadzenia czujnika oraz wałek z wytoczonymi otworami obu stron - z jednej w celu osadzenia na czujniku i drugiej w celu osadzenia w nim matrycy z zestawu nitownicy. Do pomiaru przemieszczenia nitu zastosowano pojemnościowy czujnik przemieszczenia WA10 firmy HBM o zakresie pomiaru $0 \div 10 \mathrm{~mm}$. W celu pomiaru przemieszczenia stempla konieczne było odpowiednie zamocowanie czujnika przemieszczenia oraz zderzaka, na którym czujnik byłby pozycjonowany. Do przeprowadzenia pomiarów obydwu wielkości zastosowano wzmacniacz pomiarowy Spider 8 firmy HBM, który był podłączony bezpośrednio do komputera wyposażonego w odpowiednią kartę z gniazdem umożliwiającym podłączenie wzmacniacza. Tor pomiarowy uzupełniał przetwornik analogowo-cyfrowy, sparowany przez producenta i zapewniający odpowiednią kalibrację czujnika. Czujnik przemieszczenia
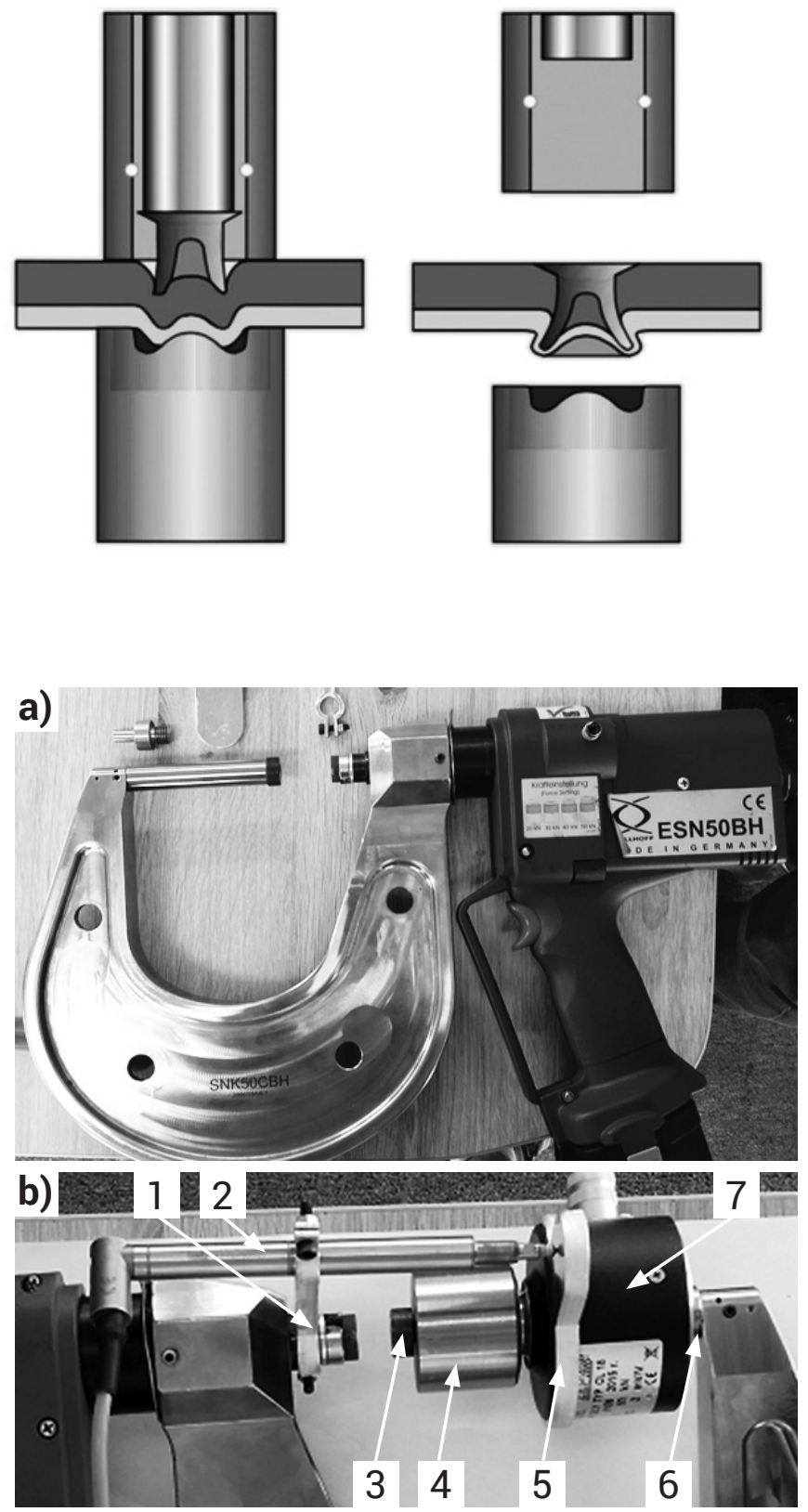

Rys. 2. Przyrząd do nitowania firmy BÖLLHOFF model ESN50BH (a), wraz z zaprojektowanymi układem pomiarowym (b): 1 - element mocujący czujnik przemieszczeń, 2 - czujnik przemieszczeń, 3 - matryca, 4 - łącznik, 5 - zderzak, 6 - element mocowania czujnika siły, 7 - czujnik siły

Fig. 2. BÖLLHOFF riveting set ESN50BH (a), including a measuring system (b): 1 - displacement sensor fastener, 2 - displacement sensor, 3 - die, 4 - connector, 5 - bumper, 6 - force transducer mounting, 7 - force transducer

natomiast był podłączony bezpośrednio do wzmacniacza Spider 8. Nitownicę wraz z osprzętem pokazano na rysunku 2b. Widać na nim mocowanie czujnika przemieszczenia do ruchomej części nitownicy ponad stemplem. Zderzak czujnika przemieszczenia jest zamocowany bezpośrednio do czujnika siły.

Specjalny uchwyt (1), posiadający dwa otwory mocujące został przytwierdzony z jednej strony do ruchomego stempla, natomiast z drugiej strony został zamocowany czujnik przemieszczenia (2). W czujnik siły (7) został wkręcony element mocowania (6), a następnie układ wsunięto w gniazdo matrycy w nitownicy. Na czujnik siły nałożono zderzak (5). Na grzybku czujnika siły nałożono spasowanym otworem łącznik (4), na którym została zamocowana matryca (3).

W pierwszej kolejności przeprowadzono kalibrację układu czujników pomiarowych. Rejestracja danych odbywała się 
poprzez specjalną aplikację dedykowaną do wzmacniacza Spider 8. Próby były rejestrowane z próbkowaniem $300 \mathrm{~Hz}$, co pozwalało na zgromadzenie wystarczającej liczby punktów pomiarowych w procesie trwającym kilka sekund. Dodatkowo prowadzony był pomiar czasu nitowania. Kalibracja czujnika siły odbyła się przez sparowanie czujnika z przetwornikiem analogowo-cyfrowym dostarczonym w zestawie przez producenta. Odczytywane były wartości napięć odpowiadające - w zależności od czujnika - różnym wartościom fizycznym. Dla czujnika siły zachowane były proporcje $10 \mathrm{~V}-50 \mathrm{kN}$, a dla czujnika przemieszczeń $8 \mathrm{~V}-10 \mathrm{~mm}$. W przeprowadzonych próbach nitowania zastosowano matrycę z płaskim dnem, rysunek 3.
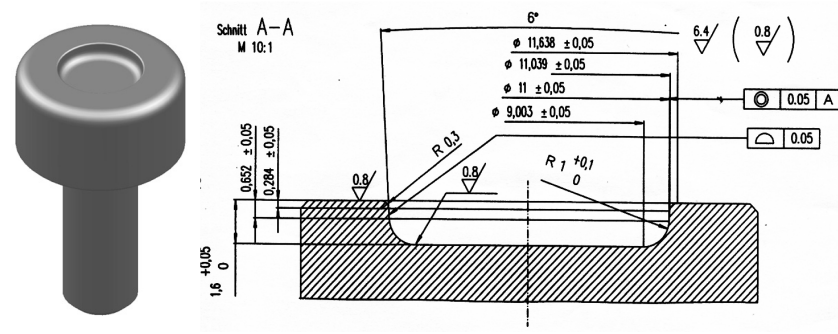

Rys. 3. Matryca zastosowania w próbach nitowania Fig. 3. Die applied for tests

W próbach nitowania wykorzystano blachę miedzianą o oznaczeniu M1Ez4. Jest to miedź elektrolityczna o zawartości pierwiastka miedzi minimum 99,9\%. Materiał ten cechuje się wysoką plastycznością, bardzo dobrą przewodnością elektryczną i termiczną. Nadaje się do emaliowania, pokrywania warstwami cynku, aluminium oraz wyżarzania. Stosowana jest przede wszystkim w przemyśle elektrycznym, elektrotechnicznym oraz elektronicznym. Produkowana jest w postaci blach, prętów, rur, drutów oraz gotowych wyrobów dla elektrotechniki jak odbiorniki ciepła, klemy itp. Nitowanie bezotworowe staje się coraz popularniejsze również w przemyśle energetycznym głównie ze względu na wysoką wytrzymałość na obciążenia dynamiczne oraz brak ingerencji w strukturę materiału podczas tworzenia połączenia, co nie obniża jego możliwości do przewodzenia prądu. Stąd zainteresowanie zakładów produkujących elementy konstrukcyjne z miedzi. W celu weryfikacji podanych przez producenta własności wykonano siedem serii prób rozciągania standardowych próbek, rysunek 4. Na tej podstawie wyznaczone zostały parametry modelu materiału miedzi zastosowane w opisie materiału w modelowaniu numerycznym, tablicy I.

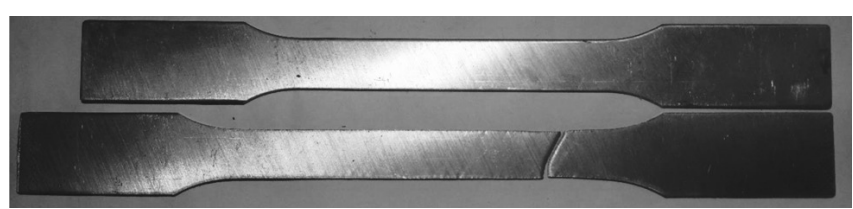

Rys. 4. Próbka z blachy miedzianej przed i po próbie rozciągania Fig. 4. Copper specimen before and after stretching test
Próby nitowania przeprowadzono z wykorzystaniem standardowego nitu $5 \times 7$, rysunek 5 . Dane materiałowe do modelowania dla nitu wykorzystano z prac $[3,4]$.

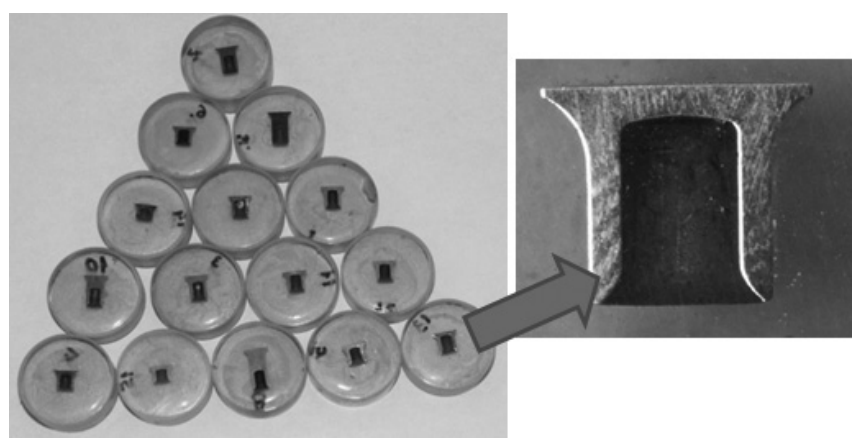

Rys. 5. Rodzaj nitu wybrany do prób, typ $5 \times 7$

Fig. 5. Selected rivet shape for tests, type $5 \times 7$

\section{Modelowanie numeryczne}

Tworzenie od podstaw kompletnego modelu numerycznego procesu nitowania jest zwykle żmudnym procesem. Spowodowane jest to szeregiem parametrów, które mają wpływ na proces, a których w jednoznaczny sposób nie można wyznaczyć. Stworzony model jest modelem koncepcyjnym, służącym do określenia warunków początkowych do testów na stanowisku badawczym oraz do tworzenia dokładniejszego schematu numerycznego. Proces nitowania był analizowany jako statyczny, izotermiczny i osiowosymetryczny (2D). W modelowaniu przyjęto sprężysto-plastyczny model materiału ze wzmocnieniem izotropowym, natomiast narzędzia - matryca, stempel, dociskacz - modelowano jako obszary sztywne. Dane materiałowe uwzględnione w modelu materiału podano w tablicy II. Zastosowano czterowęzłowe elementy skończone, a rozdzielenie górnej warstwy uwzględniono poprzez zastosowanie kryterium pękania CockroftaLathama. Problemy związane z uwzględnieniem kryterium rozdzielenia materiału oraz dopasowanie do algorytmu dynamicznej regeneracji siatki zostały opisane w różnych pracach, między innymi [4]. Tarcie modelowano wykorzystując zmodyfikowany model Coulomba, a przyjęte współczynniki tarcia pomiędzy narzędziami a materiałami odkształcanymi określono na poziomie $\mu=0,15$, natomiast na powierzchniach kontaktu elementów odkształcanych $\mu=0,2$.

Tablica II. Zestawienie wybranych wielkości wyznaczonych w próbach rozciągania

Table II. Collection of selected values determined during stretching tests

\begin{tabular}{|c|c|c|}
\hline Materiał & Moduł Younga [MPa] & Krzywa umocnienia \\
\hline Stal 10B35 (nit) & 210000 & $\sigma_{\mathrm{p}}=639 \cdot \varepsilon^{0,246}$ \\
\hline M1 (blacha) & 125000 & $\sigma_{\mathrm{p}}=380 \cdot \varepsilon^{0,29}$ \\
\hline
\end{tabular}

Tablica I. Zestawienie wybranych wielkości wyznaczonych w próbach rozciągania

Table I. Collection of selected values determined during stretching tests

\begin{tabular}{|c|c|c|c|c|c|}
\hline Nr próbki & $\mathbf{R}_{0,2}[\mathbf{M P a}]$ & $\mathbf{R}_{\mathbf{m}}[\mathrm{MPa}]$ & $\mathbf{E}[\mathrm{GPa}]$ & $\mathbf{N}$ & $\mathbf{C}[\mathrm{MPa}]$ \\
\hline 1 & 235 & 301,3 & 117,1 & 0,5715 & 369,6 \\
\hline 2 & 234 & 308,7 & 121,5 & 0,5558 & 373,0 \\
\hline 3 & 248 & 303 & 109,4 & 0,5549 & 368,1 \\
\hline 4 & 231 & 306 & 118,2 & 0,5647 & 390,1 \\
\hline 5 & 234 & 294 & 110 & 0,5841 & 375,2 \\
\hline Średnia & 236,4 & 302,6 & 115,24 & 0,5662 & 375,2 \\
\hline
\end{tabular}


W ramach optymalizacji modelu numerycznego przeanalizowano wpływ parametrów regeneracji siatki na przebieg symulacji i wyniki końcowe, a także na dopasowanie kryteriów pękania. Z kolei weryfikacja polegała na analizie wpływu współczynnika tarcia na przebieg siły procesu i porównaniu z wynikami testów, rysunek 6 . Uzyskano jakościowo dobrą zbieżność wyników. Ilościowe różnice wynikały m.in. z braku uwzględnienia w modelu numerycznym elementów sprężystych zastosowanych w oprzyrządowaniu. Ponadto zaobserwowano niewielki wpływ zmiany współczynnika tarcia na przebieg siły w modelu numerycznym. Modele numeryczne dla układu blach 1-2 mm i 2-1 mm zostały pokazane na rysunku 7 wraz z przykładowymi wynikami obliczeń uzyskiwanych w trakcie procesu optymalizacji.

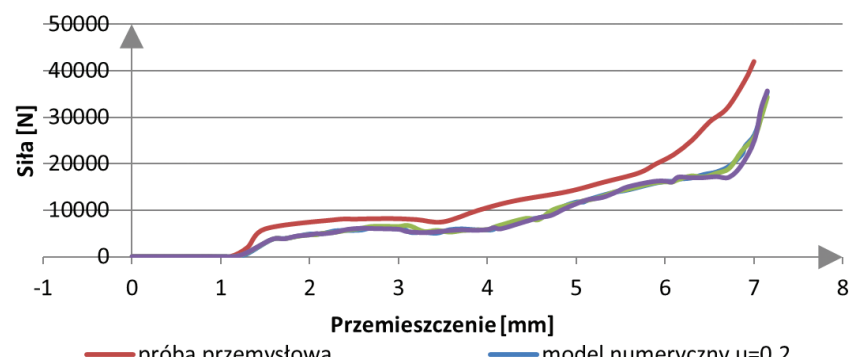

- model numeryczny $\mathrm{u}=0.25 \quad-$ model numeryczny $\mathrm{u}=0.2$

Rys. 6. Porównanie przebiegu siły procesu nitowania dla prób laboratoryjnych i modelowania numerycznego przy różnych współczynnikach tarcia

Fig. 6. Comparison of riveting force for laboratory tests and results of numerical modeling with different coefficients of friction

\section{Analiza wyników}

Przeprowadzone serie prób nitowania w różnych konfiguracjach ułożenia grubości materiałów blach względem wbijanego nitu: 1-2 mm, 2-2 mm, 2-1 mm, dostarczyły ciekawych informacji na temat łączenia, zwłaszcza układów różnoimiennych. Jednym z głównych kryteriów projektowych obecnie obowiązujących przy projektowaniu połączeń nitowanych bezotworowo jest założenie, że optymalną wytrzymałość uzyskuje się w sytuacji, gdy łączymy blachy w takim układzie, aby blacha cieńsza znajdowała się od strony wbijanego nitu. Sugeruje się, aby górna warstwa materiału była cieńsza, lub równa co do grubości warstwie dolnej. Jeśli nie można spełnić tego warunku, zalecane jest, aby grubość dolnej warstwy była nie mniejsza niż 1/3 grubości całego stosu łączonych elementów. Udokumentowano wiele przypadków łączenia blach stalowych i aluminiowych, w których dochodziło do uszkodzenia dolnej warstwy w innej sytuacji, czyli przy próbie uzyskania połączenia w odwrotnej konfiguracji - blacha grubsza od strony wbijanego nitu. Takie uszkodzenie dolnej warstwy wiąże się ze spadkiem, często znacznym, wytrzymałości połączenia. Przeprowadzone symulacje numeryczne wskazały na możliwość uzyskania połączenia bez przerwania dolnej warstwy w zaproponowanych układach dla blach miedzianych. Zostało to potwierdzone
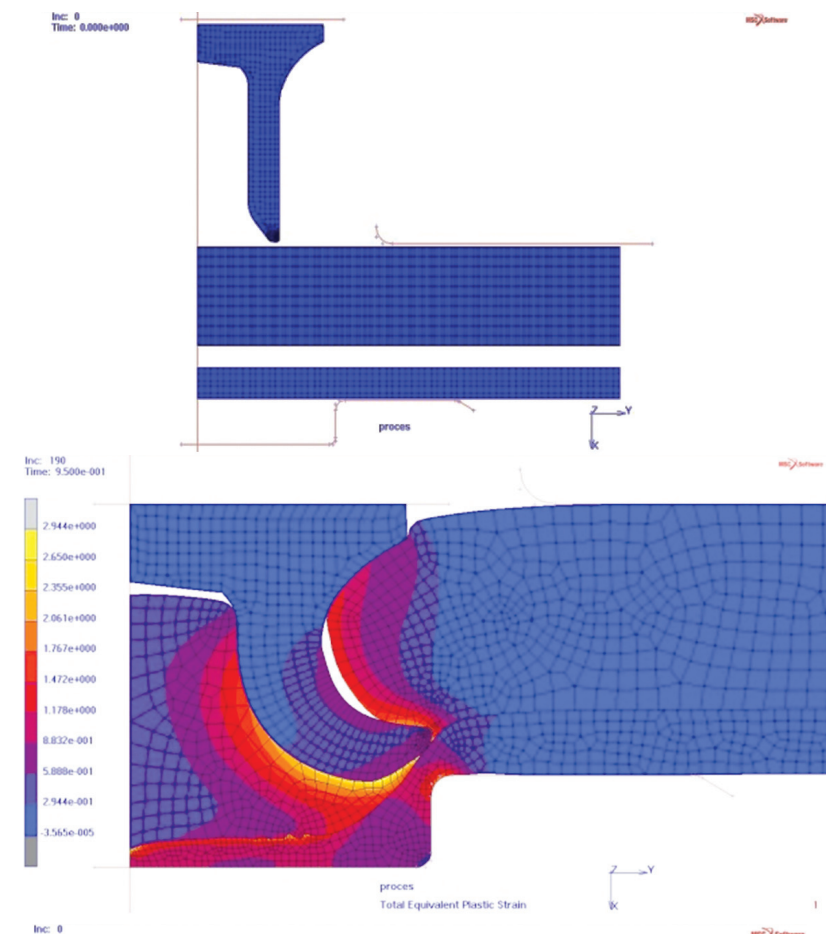

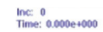
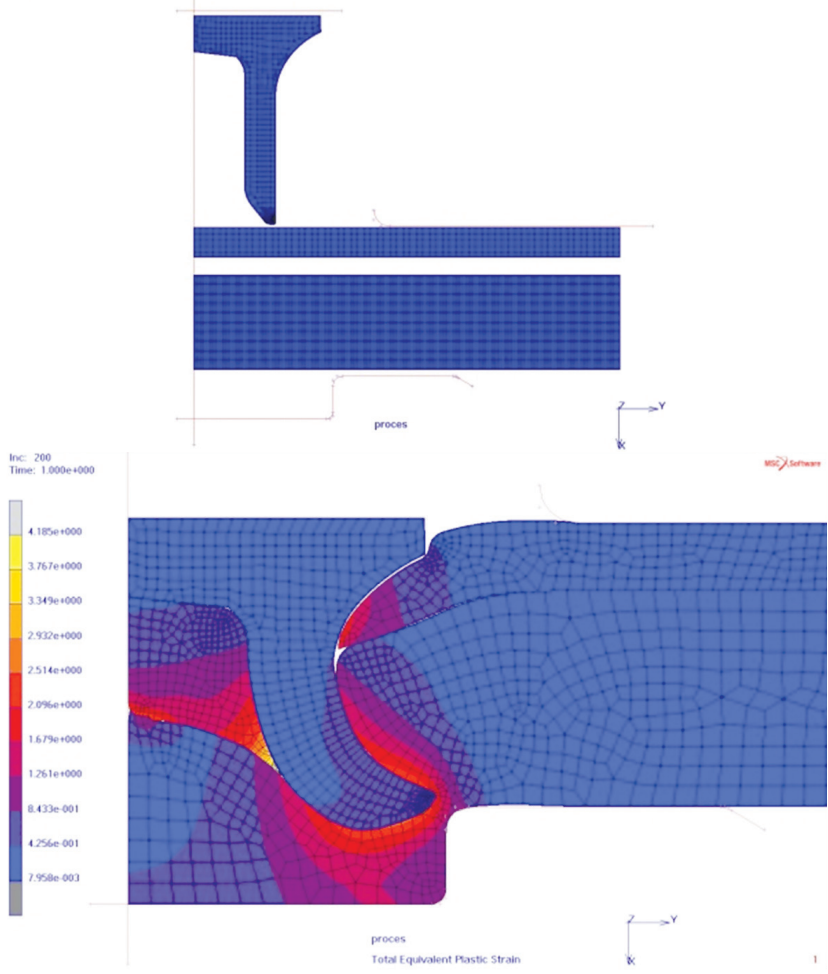

Rys. 7. Modele numeryczne dla dwóch różnych zestawów procesów nitowania o różnym ułożeniu grubszej blachy względem nitu oraz odpowiadające im przykładowe wyniki symulacji przed optymalizacją Fig. 7. Numerical models for two different sets of riveting processes - thick-thin and thin-thick - and corresponding examples of simulation results before optimization

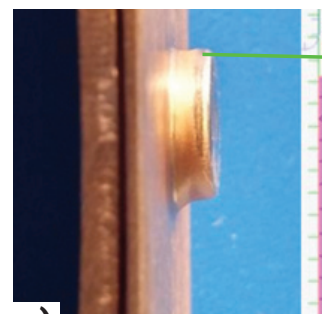

a)
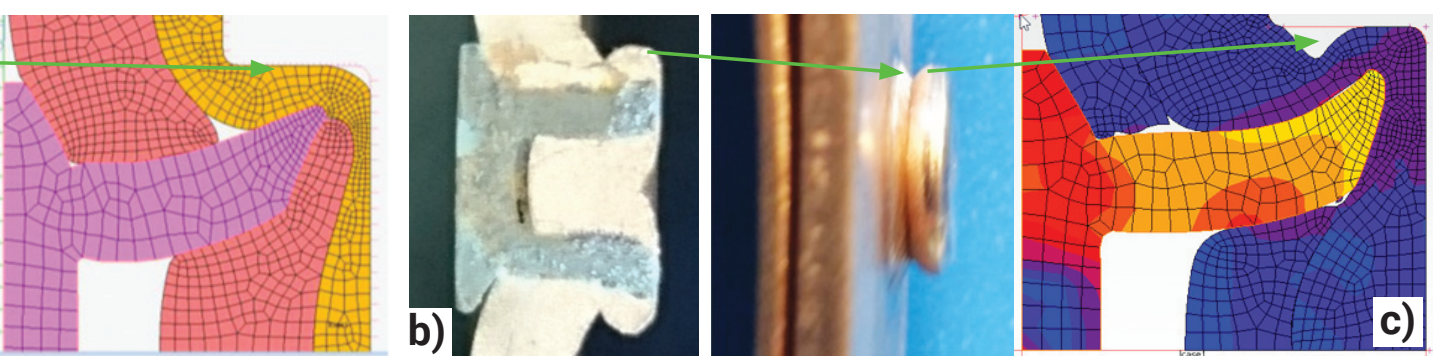

Rys. 8. Braku defektów zewnętrznego kształtu połączenia w próbach testowych i modelowaniu (a) i ich wystąpienie w próbach testowych (b) i modelowaniu numerycznym (c)

Fig. 8. The absence of external joint shape defects in tests and numerical modeling (A) and their occurrence in test (b) and numerical modeling (c) 
w testach porównawczych. Ten efekt wymaga zbadania, np. dla innych rodzajów matryc, tzw. profilowanych.

Ponadto w symulacjach komputerowych zaobserwowano dwa zjawiska, które zostały potwierdzone w próbach testowych: tworzenie się wnęki od strony matrycy i brak wypełnienia materiału pod nitem. Ciekawe jest to, że brak wypełnienia matrycy, a więc z punktu widzenia kryteriów projektowych gorszy kształt dolnej warstwy, uzyskano w potencjalnie lepszym układzie, czyli przy położeniu cieńszej blachy od strony wbijanego nitu, rysunek 8 .

\section{Wnioski}

Na podstawie wielu eksperymentów badawczych i przemysłowych opracowano podstawowe kryteria projektowania procesu nitowania bezotworowego, ale odnoszą się one przede wszystkim do elementów łączonych ze stali i stopów aluminium: - całkowita grubość łączonych elementów nie powinna przekroczyć $7 \mathrm{~mm}$ dla stali i $12 \mathrm{~mm}$ dla aluminium,

- minimalna grubość łączonych materiału dla stali i aluminium powinna wynosić 1,6 mm,

- sugeruje się, aby górna warstwa materiału była cieńsza, lub równa co do grubości warstwie dolnej; jeśli nie można spełnić tego warunku, zalecane jest, aby grubość dolnej warstwy była nie mniejsza niż 1/3 grubości całego stosu łączonych elementów.

Przeprowadzone z wykorzystaniem komercyjnych narzędzi do nitowania wstępne próby produkcyjne z wykorzystaniem jednego profilu matrycy wskazały, że żaden z tych warunków nie musi być spełniony, jeśli chodzi o blachy wykonane z miedzi.

Ponieważ wykorzystano w badaniach matrycę płaską, istnieje konieczność zweryfikowania efektów w przypadku zastosowania matryc o zmiennym przekroju dna (matryce z wyspą). Badania połączeń blach miedziany będą kontynuowane w celu szerszej weryfikacji obowiązujących kryteriów i ewentualnego zaproponowania korekty tych założeń.

\section{Literatura}

[1] Cacko R., Czyżewski P.: Numeryczne modelowanie kształtowania i obciążania połączeń nitowanych bezotworowo, in Polish, Przegląd Mechaniczny, 2005, nr 7-8, s. 50-53.

[2] Wang C.C., Kam H.K., Cheong W.C.: Effect of tool eccentricity on the joint strength in mechanical clinching process, Proceedings of the 11 th International Conference on Technology of Plasticity.

[3] Cacko R., Czyżewski P.: Verification of numerical modeling of the SPR joint by experimental stack-up, Proc. Of Computer Methods in Materials Science Vol. 7, 2007, no. 1, pp.124-130.

[4] Cacko R.: Review of different material separation criteria in numerical modeling of the self-piercing riveting process - SPR, Archives of Civil and Mechanical Engineering, 2008, Vol. VIII, No. 2, pp. 21-31.

[5] Cacko R., Czyżewski P., Kocańda A.: Initial Optimization of Self-Piercing Riveting Process by Means of FEM, The 10th Int.Conf. METAL FORMING 2004, 19-22 Wrzesień 2004, Akademia Górniczo-Hutnicza KRAKÓW, Steel Grips 2 (2004) Suppl. Metal Forming, pp. 307-310.

[6] Cacko R., Czyżewski P.: Analiza wpływu modyfikacji kształtu matrycy i nitu na proces nitowania bezotworowego SPR, Przegląd Mechaniczny, nr 7-8, 2007, s. 41-44.
[7] Hahn O., Schulte A.: Performance and Reliability of Self-Piercing Riveted Joints in Steel and Aluminum Alloys. Mechanical Fastening Seminar, Troy, Michigan, January 1998, pp. 1-13.

[8] Bokhari N., LaPensee M.: Self-Piercing Riveting in Automotive Applications. Mechanical Fastening Seminar, Troy, Michigan, January 1998, pp. 17-22.

[9] TWI World Centre for Materials Joining Technology - Self-Piercing Riveting database, available at www.twi.co.uk.

[10] Porcaro, R., Hanssen, A.G., Langseth, M., Aalberg A.: Self-piercing riveting process: An experimental and numerical investigation, Journal of Materials Processing Technology, 171, 2006, pp. 10-20.

[11] Abea, Y., Kato, T., Mori, K.: Joinability of aluminium alloy and mild steel sheets by self piercing rivet, Journal of Materials Processing Technology, 177, 2006, pp. 417-421.

[12] Porcaro R., Hanssen A.G., Langseth M., Aalberg A.: The behaviour of a self-piercing riveted connection under quasi-static loading conditions, International Journal of Solids and Structures 43, 2006, pp. 5110-5131. 